\author{
Universidade de Brasília \\ Instituto de Psicologia
}

Pós-Graduação em Ciências do Comportamento

\title{
ANÁLISE DE METACONTINGÊNCIAS DA LEI 12.608/12 QUE DEFINE A POLÍTICA NACIONAL DE PROTEÇÃO E DEFESA CIVIL
}

Rodrigo Ferreira Kill

Brasília, DF

Julho de 2016 
Universidade de Brasília

Instituto de Psicologia

Pós-Graduação em Ciências do Comportamento

\section{ANÁLISE DE METACONTINGÊNCIAS DA LEI 12.608/12 QUE DEFINE A POLÍTICA NACIONAL DE PROTEÇÃO E DEFESA CIVIL}

Rodrigo Ferreira Kill

Dissertação apresentada ao Departamento de Processos Psicológicos Básicos do Instituto de Psicologia da Universidade de Brasília como requisito parcial para obtenção do título de Mestre em Ciências do Comportamento.

Orientadora: Professora $\mathrm{Dr}^{\mathrm{a}}$. Laércia Abreu Vasconcelos

Brasília, DF

Julho de 2016 


\section{Sumário}

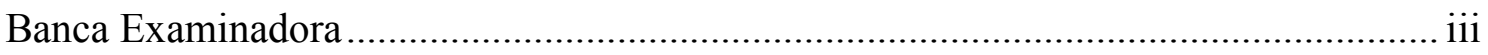

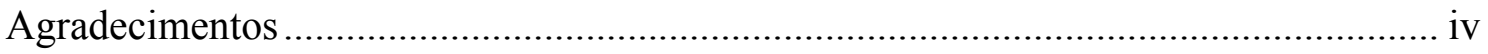

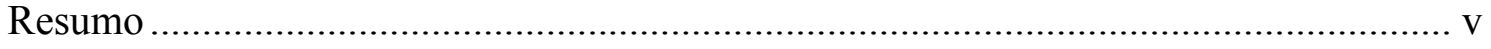

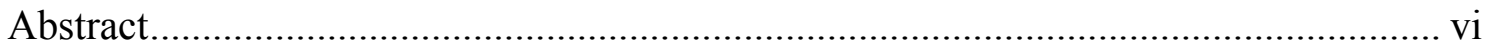

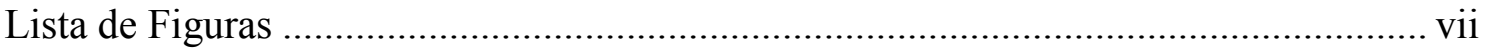

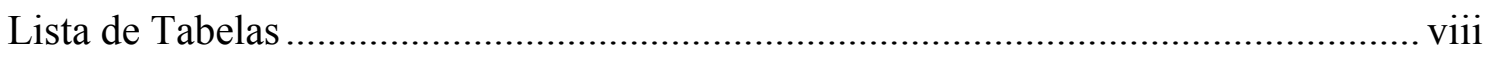

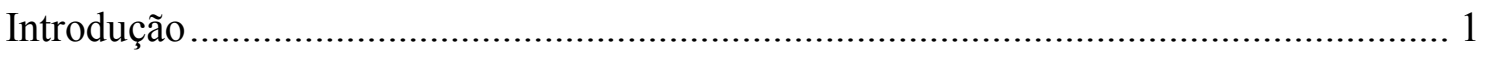

Práticas Culturais e Metacontingências .................................................................... 2

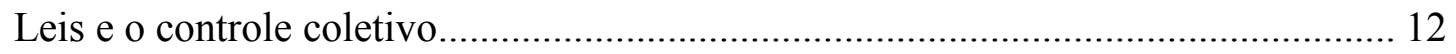

Desastres: A busca por macrocomportamentos de precaução e protetivos ................ 15

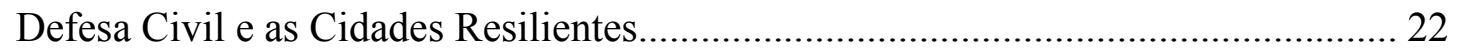

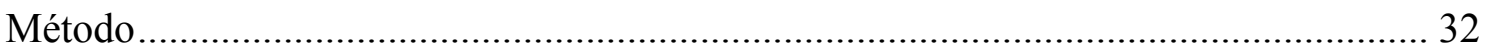

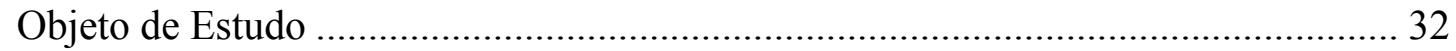

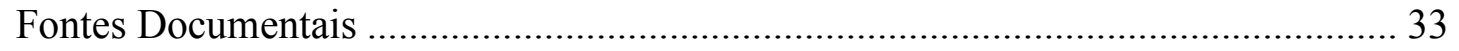

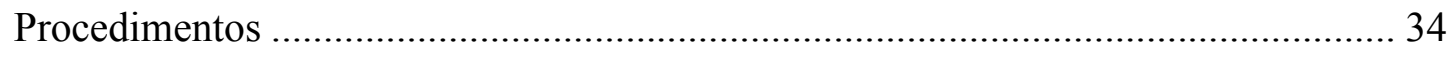

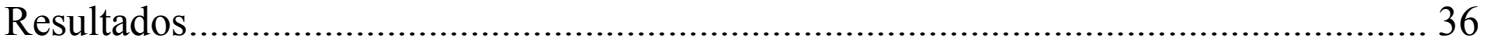

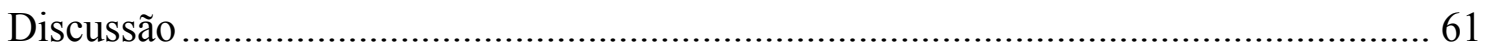

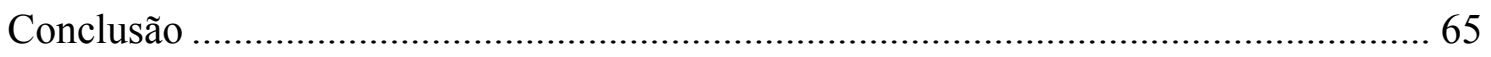

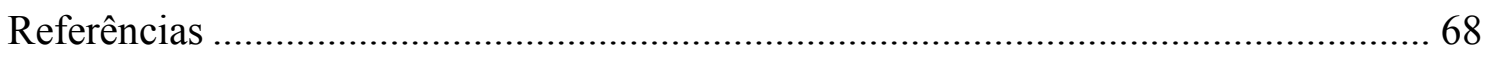

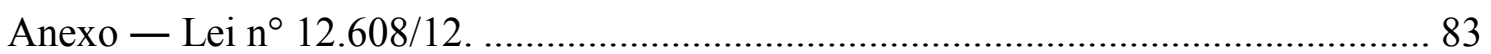




\section{Banca Examinadora}

Prof $^{\mathrm{a}}$. Dr ${ }^{\mathrm{a}}$. Laércia Abreu Vasconcelos - Presidente Universidade de Brasília

Prof. Dr. Airton Bodstein de Barros - Membro Efetivo Externo Universidade Federal Fluminense

Prof $^{\mathrm{a}}$. Dr ${ }^{\mathrm{a}}$. Rachel Nunes da Cunha-Membro Efetivo

Universidade de Brasília

Prof. Dr. Márcio Borges Moreira - Suplente

Centro Universitário de Brasília - UniCEUB 


\section{Agradecimentos}

Em primeiro lugar, agradeço a Deus por nos mostrar dia-a-dia a importância da fé e de cultivar bons momentos junto das pessoas a quem se ama e ajudar o próximo. Talvez seja esse o simples sentido da vida, pois as adversidades e dificuldades são elementos pequenos e passageiros, sempre.

A minha família e a minha noiva Dayane, pelo apoio incondicional, incentivo e a compreensão em todos os momentos do mestrado, um projeto incrível e repleto de contingências que alteram de forma permanente nossos comportamentos. Uma experiência única.

A prof $\mathrm{f}^{\mathrm{a}}$ Laércia, pelo aceite em orientar um "analista interdisciplinar" em novos caminhos de pesquisa na Análise do Comportamento Aplicada. Agradeço toda a atenção e dedicação em compartilhar seus conhecimentos. Estendo meu agradecimento aos professores Airton, Rachel e Márcio pelo aceite na participação da banca deste trabalho, suas contribuições nesse estudo foram preciosas.

Aos amigos da pós e a toda equipe da secretaria do PPB (em especial ao Rodolfo e Daniel), agradeço pelo grande apoio dentro e fora de sala de aula durante todo o curso.

Aos estudantes e curiosos de outras áreas que estejam lendo esse trabalho, meu obrigado, e que o conteúdo dessa pesquisa possa contribuir em seus projetos ou no conhecimento acerca desse imenso universo interdisciplinar (ainda a ser explorado) entre a Análise do Comportamento e a gestão de riscos de desastres. 
Kill, R. F. (2016). Análise de Metacontingências da Lei 12.608/12 que define a

Política Nacional de Proteção e Defesa Civil. Dissertação de Mestrado. Programa de Pós-Graduação em Ciências do Comportamento. Universidade de Brasília - UNB.

\section{Resumo}

Segundo a Organização das Nações Unidas em 2015, o Brasil foi classificado como o único país das Américas presente no ranking mundial das 10 nações com maior número de pessoas atingidas por desastres. O presente estudo investigou a Lei Federal $\mathrm{n}^{\mathrm{o}}$ 12.608/12, principal instrumento que estabelece as diretrizes nacionais do complexo sistema de Proteção e Defesa Civil, responsável pelo gerenciamento, prevenção e resposta em situações de desastres. A análise da Lei $\mathrm{n}^{\circ}$ 12.608/12 seguiu o modelo de análise funcional de contingências e metacontingências em leis desenvolvido por Todorov (1987, 2005; Todorov, Moreira, Prudêncio e Pereira, 2004). A análise foi dividida em seis fases: (1) e (2) Identificação das principais contingências e metacontingências presentes no texto da lei, respectivamente; (3) Definição das interações da Lei $\mathrm{n}^{\circ}$ 12.608/12 com outras leis; (4) Síntese dos 31 artigos da lei, identificando múltiplos agentes atuando em redes de contingências comportamentais entrelaçadas (CCE); (5) Análise descritiva sobre a composição textual da lei, com base na frequência de repetição de termos-chave; (6) Descrição do cenário governamental brasileiro de gestão de riscos de desastres, identificando produtos agregados (PA), consequências culturais (CC) e o ambiente selecionador a partir da Lei $\mathrm{n}^{\circ} 12.608 / 12$. Os resultados destacam duas metacontingências centrais que apoiam os 31 artigos presentes na lei. Entre eles, $23 \%$ dos artigos descrevem o principal produto gerado: A Política Nacional de Proteção e Defesa Civil - PNPDEC; 47\% das metacontingências descritas nos artigos da lei estabelecem entrelaçamentos específicos com outras cinco leis. As entidades municipais predominam em 32\% dos entrelaçamentos identificados. Por fim, a Lei $\mathrm{n}^{\circ}$ 12.608/12 apresenta metacontingências comportamentais incompletas, mas caracteriza-se como um instrumento jurídico que amplia as redes de interação entre a sociedade e agentes públicos em diversos níveis, buscando aumentar a eficiência das ações governamentais no estabelecimento de políticas de prevenção e gerenciamento de riscos de desastres.

Palavras-chave: defesa civil; desastres; leis; metacontingência; macrocomportamento. 


\begin{abstract}
According to the United Nations Organization in 2015, Brazil was ranked as the only country in the Americas present in the world ranking of 10 nations with the highest number of people affected by disasters. This study investigated the Federal Law $12.608 / 12$, the main instrument establishing national guidelines complex Protection and Civil Defense system, responsible for the management, prevention and response in disaster situations. Analysis of Law 12.608/12 followed the functional analysis model of contingencies and metacontingencies in laws developed by Todorov (1987, 2005; Todorov, Moreira, Prudêncio \& Pereira, 2004). The analysis was divided into six phases: (1) and (2) Identification of the main contingencies and metacontingencies in the text of the law, respectively; (3) Definition of interactions between Law 12.608/12 with other laws; (4) Synthesis of the 31 articles of the law, identifying multiple agents acting in networks of interlocking behavioral contingencies (IBC); (5) Descriptive analysis on the textual composition of the law, based on the repetition frequency of especific keywords; (6) Description of the brazilian government framework disaster risk management, identifying aggregates products (AP), cultural consequences (CC) and selecting environment from the Law 12.608/12. The results demonstrate the presence of two main metacontingencies that support the 31 articles present the law. Among them, $23 \%$ of the articles describe the main product generated: The National Policy on Protection and Civil Defense; $47 \%$ of the metacontingencies present in the law establish specific interlocking with five other laws. In municipal entities prevail $32 \%$ of the identified passage. Finally, Law 12.608/12 provides incomplete behavioral metacontingencies but is characterized as a legal instrument that expands and interact in networks with society and public authorities at various levels, contributing to the government's action is effective in establishing a policy disaster prevention and risk management.
\end{abstract}

Keywords: civil defense; disasters; laws; metacontingency; macrobehavior. 


\section{Lista de Figuras}

Figura 1. Principais mudanças no contexto nacional e internacional na área de gestão de desastres em sete décadas. 26

Figura 2. Metacontingências previstas no Capítulo I da Lei n $12.608 / 12$. 38

Figura 3. Metacontingências previstas no Capítulo II sobre a Política Nacional de Proteção e Defesa Civil.

Figura 4. Metacontingências incompletas previstas no Capítulo III sobre o Sistema Nacional de Proteção e Defesa Civil.

Figura 5. Metacontingências incompletas previstas no Capítulo III sobre o Conselho Nacional de Proteção e Defesa Civil.

Figura 6. Metacontingências incompletas previstas no Capítulo IV sobre a transferência de recursos da União para os agentes do sistema de Defesa Civil. 43

Figura 7. Intervenção da Lei $\mathrm{n}^{\circ} 12.608 / 12$ sobre outras cinco leis brasileiras. 44

Figura 8. Frequência de interações entre os principais grupos de agentes na Lei ${ }^{\circ}$ $12.608 / 12$

Figura 9. Metacontingências no cenário governamental brasileiro de gestão de riscos de desastres, com a inclusão de possíveis ambientes selecionadores 59 


\section{Lista de Tabelas}

Tabela 1. Principais mudanças conceituais na definição de Metacontingências. 5

Tabela 2. Estudos experimentais sobre metacontingências e macrocontingências entre 2008 e 2015.

Tabela 3. Análises de contingências e metacontingências em leis publicadas de 1987 à 2016.

Tabela 4. Lista dos desastres com grande repercussão no Brasil entre 1961 e 2015... 19

Tabela 5. Estrutura da Lei $n^{\circ} 12.608 / 12$.

Tabela 6. Análise da principal metacontingência presente no Capítulo I da Lei $n^{\circ}$

$12.608 / 12$.

Tabela 7. Responsabilidades compartilhadas entre os três niveis governamentais na

Lei $n^{\circ} 12.608 / 12$. 40

Tabela 8. Intervenções na Lei $n^{\circ} 12.340 / 10$. 46

Tabela 9. Intervenções da Lei $n^{\circ}$ 12.608/12 sobre o Cadastro Nacional de Municípios com áreas suscetíveis à ocorrência de desastres, previsto na Lei $n^{\circ} 12.340 / 10$.

Tabela 10. Intervenção na Lei $n^{\circ} 10.257 / 01$.

Tabela 11. Intervenção na Lei $n^{\circ} 8.239 / 91$. 50

Tabela 12. Intervenção na Lei $n^{\circ}$ 9.394/96. 50

Tabela 13. Artigos da Lei $n^{\circ}$ 12.608/12 e grupos de agentes envolvidos nas CCEs...... 52

Tabela 14. Frequência de repetição de termos-chave da Lei $n^{\circ} 12.608 / 12$. 56 


\section{Introdução}

Em 1953 Skinner reconhece a complexidade no estudo científico do comportamento, um objeto dinâmico da natureza dos organismos, difícil de ser isolado para análise, porém passível de controle e previsibilidade. Assim, o conceito de comportamento envolve interações com elementos ambientais no transcorrer do período de vida do organismo.

A filosofia denominada Behaviorismo Radical fundamenta a Ciência da Análise do Comportamento, a qual propõe uma abordagem sistêmica na resolução de problemas humanos, partindo do pressuposto de uma relação causal ou funcional em que o comportamento é resultado de três possíveis fontes de variação e seleção em diferentes durações temporais: a) A filogenia ou características inatas dos organismos, que são próprias de cada espécie e demandam milhões de anos em seus processos de seleção de uma estrutura biológica de uma espécie; b) Com a ontogenia, há variação comportamental de características individuais desenvolvidas ao longo da existência do organismo, e c) No nível cultural, há o surgimento e a transmissão de padrões comportamentais aprendidos como práticas culturais recorrentes e organizadas.

Skinner (1953/2007) considerou com interpretações do nível cultural de seleção, o planejamento cultural determinante para a sobrevivência e evolução de práticas culturais, especialmente quando são identificadas complexas matrizes de contingências e produtos culturais com efeitos adversos para um povo. Nesta área, o conceito de comportamento social foi apresentado por Skinner na década de 1960: “(...) o comportamento de duas ou mais pessoas, uma em relação à outra ou, em conjunto, em relação a um ambiente comum" (Skinner, 1969/1984, p.171). Portanto, os princípios sobre fenômenos comportamentais podem ser estendidos para intervenções efetivas em 
processos mais complexos da sociedade. No nível cultural, em geral, os processos envolvem muitas gerações para se fortalecerem ou extinguirem (Skinner, 1971/1983).

A partir do planejamento cultural, questões de pesquisa podem ser formuladas investigando a construção e os processos característicos de um ambiente cultural. As condições para o planejamento envolvem o desenvolvimento, interação de grandes grupos em geral, e o desafio de uma transmissão eficiente das práticas culturais entre gerações (Skinner, 1969/1984).

\section{Práticas Culturais e Metacontingências}

A obra de ficção social Walden Two (Skinner, 1948/1975) é descrita pelos analistas do comportamento como referência literária na área que fez emergir possibilidades para delineamentos culturais no estudo experimental de fenômenos sociais complexos, conforme propôs o autor:

Os homens agem sobre o mundo, modificam-no e, por sua vez são modificados pelas consequências de sua ação. Alguns processos que o organismo humano compartilha com outras espécies alteram o comportamento para que ele obtenha um intercâmbio mais útil e mais seguro em determinado meio ambiente. Uma vez estabelecido um comportamento apropriado, suas consequências agem através de processos semelhantes para permanecerem ativas. Se, por acaso, o meio se modifica, formas antigas de comportamento desaparecem, enquanto novas consequências produzem novas formas. (Skinner, 1957/1978, p.15)

A filosofia do behaviorismo radical inova ao introduzir a função selecionista do ambiente, indo além da seleção natural ao incluir novos repertórios comportamentais (Skinner, 1981), linhagens operantes e linhagens culturo-comportamentais recorrentes, transmitidas entre gerações (Malott \& Glenn, 2006). Analistas do comportamento têm contribuído nas últimas três décadas para o desenvolvimento de novos conceitos que possibilitem a análise de fenômenos culturais com base em premissas estabelecidas pelo 
behaviorismo radical, para melhor compreender e explicar comportamentos e mudanças sociais (e.g., Glenn, 1986; Todorov, 1987; Glenn \& Malott, 2004; Houmanfar \& Rodrigues, 2006; Martone, 2008; Vichi, Andery \& Glenn, 2009; Sandaker, 2009; Tourinho, 2013; Vasconcelos, 2015; Glenn, Malott, Andery, Benvenuti, Houmanfar, Sandaker, Todorov, Tourinho, \& Vasconcelos, 2016).

A evolução conceitual na área tem contribuído para o desenvolvimento de pesquisas experimentais, o que tem resultado em avanços nos trabalhos empíricos e teóricos sobre fenômenos culturais (Vichi, Andery \& Glenn, 2009). Pesquisas no nível de seleção cultural mostram que a habilidade humana inata de imitar comportamento de outros indivíduos contribui mas não isoladamente para a evolução de uma cultura (Glenn, 2003), o que exige estudos sobre determinadas formas em que estas contingências estão organizadas e sobre a transmissão desses comportamentos a outras gerações, por meio das práticas culturais, definidas como "padrões de comportamento aprendido e transmitido socialmente, bem como os produtos deste comportamento objetos, tecnologias, organizações" (Glenn, 2004, p.139).

Com o objetivo de criar uma unidade de análise para o estudo de fenômenos culturais, Sigrid Glenn desenvolveu em 1986 o termo metacontingência ao analisar as diferenças entre a cultura americana e a comunidade proposta por Skinner em Walden Two. Na proposta da autora, o arranjo de contingências seria responsável pela produção de efeitos no ambiente que não poderiam ser produzidos por um único indivíduo. Desta forma, metacontingência foi conceituada inicialmente como:

(...) unidade de análise que descreve as relações funcionais entre uma classe de operantes, cada operante possuindo suas consequências únicas e imediatas, e uma consequência de longo prazo comum a todos os operantes na metacontingência. Metacontingências devem ser mediadas por contingências de reforçamento socialmente arranjadas. (Glenn, 1986, p.2) 
Em 1988, Glenn apresenta a segunda definição de metacontingência, dando ênfase na ação seletiva do ambiente sobre as contingências comportamentais entrelaçadas (CCE), juntamente com seu produto agregado (PA), possibilitando sua recorrência. Glenn e Malott (2004) ampliaram o contexto de aplicabilidade das metacontingências, propondo uma terceira definição que passa a considerar de forma mais sistêmica os efeitos ambientais diferentes oriundos do entrelaçamento de contingências, dentre eles o produto agregado produzido por tal entrelaçamento e principalmente o chamado sistema receptor que selecionará as consequências desse entrelaçamento. Posteriormente, Glenn (2010) substituiu o termo sistema receptor por ambiente selecionador, que gera as consequências culturais (CC), selecionando PAs e CCEs. A definição mais recente de metacontingências foi estabelecida a partir de uma convenção que reuniu analistas do comportamento para discussão e padronização das terminologias utilizadas em publicações e estudos da análise do comportamento sobre fenômenos culturais (Glenn et al., 2016). Nesta quarta definição, metacontingência descreve a relação entre CCEs recorrentes, geradoras de PAs, e o ambiente selecionador (Glenn et al., 2016). A síntese da evolução do termo metacontingência é descrita na Tabela 1. 
Tabela 1. Principais mudanças conceituais na definição de Metacontingências.

\begin{tabular}{|c|c|}
\hline Metacontingência & Inovação conceitual \\
\hline $\begin{array}{l}\text { “(...) unidade de análise que circunscreve uma prática } \\
\text { cultural, em todas as suas variações, e o efeito agregado } \\
\text { de todas as atuais variações. Os efeitos das práticas } \\
\text { culturais devem, claro, ser especificados empiricamente. } \\
\text { (...) A relação funcional entre as práticas culturais e seus } \\
\text { produtos retroage às culturas por meio do processo de } \\
\text { seleção.” (Glenn, 1988, p.168) }\end{array}$ & $\begin{array}{l}\text { Primeira alteração no conceito original de } \\
\text { metacontingência, com ênfase na ação } \\
\text { seletiva do ambiente sobre as contingências } \\
\text { entrelaçadas, juntamente com seus produtos, } \\
\text { possibilitando sua recorrência. }\end{array}$ \\
\hline $\begin{array}{l}\text { "(...) relações entre contingências comportamentais } \\
\text { entrelaçadas e um ambiente selecionador. (...) } \\
\text { metacontingências apresentam três componentes: } \\
\text { contingências comportamentais entrelaçadas, um } \\
\text { produto agregado e um sistema receptor. O sistema } \\
\text { receptor é o recipiente do produto agregado, e, assim, } \\
\text { funciona como o ambiente selecionador das } \\
\text { contingências comportamentais entrelaçadas. As } \\
\text { contingências comportamentais entrelaçadas cessarão } \\
\text { sua recorrência se não houver demanda pelos seus } \\
\text { produtos." (Glenn \& Malott, 2004, p.100) }\end{array}$ & $\begin{array}{l}\text { Composição da metacontingência com três } \\
\text { elementos, por meio das CCEs, PAs e um } \\
\text { sistema receptor. }\end{array}$ \\
\hline $\begin{array}{l}\text { "Relação contingente entre 1) contingências } \\
\text { comportamentais entrelaçadas recorrentes gerando um } \\
\text { produto agregado e 2) seleção ambiental de eventos ou } \\
\text { condições." (Glenn et al., 2016, p.13) }\end{array}$ & $\begin{array}{l}\text { Refinamento da terminologia com dois } \\
\text { elementos, agregando a recorrência de CCEs } \\
\text { para produção de PAs e padronização do } \\
\text { termo ambiente selecionador em substituição } \\
\text { ao termo sistema receptor. }\end{array}$ \\
\hline
\end{tabular}

Metacontingências são também afetadas por variáveis como o contexto cultural, interagindo com estímulos antecedentes e com as regras que mediam socialmente as consequências (Hayes \& Houmanfar, 2004; Malott \& Glenn, 2006; Glenn, 2008). Desde a primeira definição em 1986, o conceito de metacontingências tem sido amplamente usado e discutido por analistas do comportamento, recebendo novas complementações e reformulações teóricas buscando uma explicação mais completa e precisa sobre a seleção e manutenção das práticas culturais (Martone \& Todorov, 2007).

Adicionalmente, o conceito de macrocomportamentos contribui para os estudos sobre práticas culturais, definido por Glenn et al. (2016) como “o comportamento operante socialmente aprendido e observado nos repertórios de vários membros de um 
sistema cultural" (p.18). Esses operantes também podem gerar um efeito acumulativo não contingente com o comportamento isolado dos indivíduos ou de CCEs, resultando em uma macrocontingência, descrita como a "relação entre 1) comportamento operante governado por contingências individuais e/ou CCEs governadas por metacontingências e 2) um efeito acumulativo de significado social” (Glenn et al., 2016, p. 19).

Todorov, Moreira, Prudêncio e Pereira (2004) ressaltam a importância da transposição dos resultados da pesquisa básica em pesquisas sociais, com o desafio de atuar na resolução de problemas típicos do indivíduo, mesmo que quando tais problemas resultem de um planejamento cultural deficiente. Nesse aspecto, Glenn (2004) fundamenta a importância da linhagem culturo-comportamental na transmissão entre gerações:

A cultura começa com a transmissão de conteúdo comportamental, aprendido por um organismo ao longo de sua vida, para o repertório de outros organismos. Portanto, o lócus dos fenômenos culturais é supraorganísmico. Diferente da aprendizagem, que se localiza em relações temporais repetidas entre as ações de um único organismo e outros eventos empíricos, o lócus das coisas culturais é supraorganísmico porque envolve repetições do comportamento inter-relacionado de dois ou mais organismos. Essa transmissão não requer nenhum traço biológico ou processo comportamental novo, mas ela inicia um novo tipo de linhagem: uma linhagem culturocomportamental. (p. 139)

Em diversas ocasiões da sociedade, contingências comportamentais entrelaçadas ocorrem de forma única, sem gerar recorrência dos produtos agregados. Glenn et al. (2016) descreve como cultural cusp “a junção de um único e não recorrente entrelaçamento e/ou contingências individuais de comportamento que resultam em um produto que conduz a mudança sociocultural significativa" (p. 21). Os autores exemplificam a Declaração da Independência dos Estados Unidos como produto agregado do Congresso Americano, resultado da interação específica entre 13 colônias 
inglesas. Apesar de único, este produto gerou mudanças culturais representativas e novas CCEs no país como leis, guerras, migração populacional, expansão comercial e industrial.

Laboratórios voltados para o estudo de metacontingências e macrocontingências no Brasil aumentaram significativamente nos últimos 10 anos para além da PUC-SP, UFPA e UnB. O Brasil ocupa uma posição de destaque no cenário internacional da Análise do Comportamento quanto ao número de pesquisadores envolvidos e experimentos, bem como pesquisas documentais sobre fenômenos culturais na abordagem teórica da Análise do Comportamento.

Novos avanços na definição do termo metacontingências contribuíram para alterar o foco da seleção para um conjunto incluindo as práticas culturais e PAs envolvidos (Glenn, 2008; Malott \& Glenn, 2006). Neste complexo contexto social em que os comportamentos ocorrem, Sampaio e Andery (2007) entendem que a prática cultural:

(...) pode ser definida como um ou mais comportamentos operantes similares (entrelaçados ou não) propagados através de sucessivos indivíduos. A similaridade dos comportamentos envolvidos pode ser topográfica ou funcional. Os sucessivos indivíduos através dos quais os comportamentos são propagados não precisam ser de diferentes gerações (no sentido biológico do termo). Além disso, não há um tempo pré-definido pelo qual os comportamentos precisem ser propagados para denominarmos um fenômeno uma prática cultural. A análise de práticas culturais envolve questões relativas aos mecanismos básicos pelos quais elas se propagam e evoluem, às unidades de análise pertinentes e a como lidar com conjuntos complexos de práticas culturais inter-relacionadas. (p.116)

Baum (2005) também utiliza a perspectiva analítica-comportamental para abordar a transmissão de práticas culturais: 
(...) Uma cultura pode ser compreendida como comportamento operante, tanto verbal como não verbal. A aprendizagem operante como resultado de pertencer a um grupo implica a programação de consequências para seus membros. Em uma sociedade humana, os pais programam reforços para o comportamento de seus filhos. (p. 261)

Para Fraley (1988), qualquer intervenção cultural deve ter como foco o indivíduo, no entanto ressalta a responsabilidade dos planejadores culturais para a necessidade de análise distinta entre as dimensões grupais e individuais, sendo fundamental a descoberta das variáveis presentes e em operação entres esses níveis. Ao se referirem a esses níveis, Malott e Glenn (2006) consideram as CCEs como entidades culturais por agregarem mais do que linhagens operantes de indivíduos. Em outra perspectiva, Houmanfar e Rodrigues (2006) percebem as CCEs como entidades comportamentais pois descreveriam outro nível do comportamento no nível cultural.

Glenn (2004) reitera que as CCEs descrevem a inter-relação dos comportamentos individuais em um grupo, e que essas contingências comportamentais entrelaçadas geram produtos agregados passíveis de seleção por um ambiente selecionador; metacontingências derivam de contingências comportamentais e não tratam de uma pura e simples soma de contingências individuais, mas de um entrelaçamento em níveis mais complexos (Glenn, 1991).

Práticas culturais envolvem a recorrência de comportamentos operantes de vários indivíduos no decorrer do tempo. Glenn (2004) descreve que apesar dos comportamentos dos indivíduos serem mantidos pelas consequências, o entrelaçamento dessas contingências é selecionado por consequências culturais que operam de maneira interdependente, resultando em relações funcionais entre as contingências comportamentais entrelaçadas (CCEs), produtos agregados (PAs) e consequências culturais $(\mathrm{CCs})$ que determinam a probabilidade de recorrência de tais comportamentos e produtos (CCEs + PAs). Em outra importante dimensão de análise, Glenn (1986) 
apresenta que metacontingências podem ser categorizadas enquanto processo cultural na forma 1) tecnológica ou 2) cerimonial:

O controle cerimonial pode ser exemplificado pela expressão: 'Faça porque estou dizendo para fazê-lo'. Já o controle tecnológico pode ser exemplificado, primeiro, pelo comportamento que participa das contingências naturais de reforçamento por contingências sociais planejadas que mediam as relações entre comportamentos e os efeitos resultantes em metacontingências tecnológicas ('Faça isso, pois o resultado será melhores condições de saneamento, por consequência, melhores condições de saúde') (...) A rápida evolução cultural ocorre em culturas no momento em que os processos cerimoniais desfalecem e processos tecnológicos pressionam de forma incontrolável, produzindo massivas mudanças em curtos espaços de tempo. Tais mudanças possibilitam a oportunidade para o surgimento de novo controle cerimonial, pois um novo grupo poderoso passa a ter o controle através da autoridade e do status ganhos em decorrência do seu papel no desenvolvimento de tecnologias avançadas. Os vários grupos cujo comportamento tecnológico produziu as mudanças revolucionárias, agora, adquiriram status e tendem a estacionar a evolução cultural e manter o controle pela autoridade. Controle cerimonial mantemse por si só, controle tecnológico assegura mudança. (Glenn, 1986, p. 16)

Uma metacontingência tecnológica descreve comportamentos mantidos por mudanças específicas (planejadas) no ambiente, cujos reforços originam-se da utilidade para o indivíduo responsável pelo comportamento, como também para os demais integrantes do grupo, observando constantemente os resultados destes comportamentos, possibilitando mudanças na relação ambiente-comportamento. Diferentemente da metacontingência cerimonial, onde os reforços com origem no poder do agente são responsáveis pela manutenção dos comportamentos independente de qualquer relação com as mudanças do ambiente, não importando os benefícios para quem se comporta.

Glenn (1986) complementa parte da distinção entre metacontingências tecnológicas e cerimoniais por meio da influência e eficiência do tipo de controle. O controle cerimonial apresenta-se em diferentes contextos culturais e são muitas vezes 
seguidos por controle tecnológico. As duas formas fortalecem as práticas culturais de um povo e o equilíbrio entre essas formas de controle beneficia a sobrevivência de uma cultura. Ressalta-se também o processo de mudança envolvendo possíveis processos tecnológicos que no transcorrer da história podem adquirir controle cerimonial. Metacontingências tecnológicas podem trazer prejuízos a um planejamento cultural adequado à medida que a metacontingência demonstra ser menos sensível a inovações sociais (Todorov, 1987). O autor ainda identifica que o planejamento cultural proposto por Skinner (1953/2007) assemelha-se à metacontingências tecnológicas, à medida que uma cultura ideal deveria necessariamente promover situações deliberadas que acompanhassem a evolução do ambiente.

Analistas do comportamento têm buscado inovar na elaboração de métodos de pesquisa que viabilizem o estudo de metacontingências em laboratório, criando procedimentos experimentais da seleção de práticas culturais ou macrocomportamentos, conforme demonstrado na Tabela 2. Para Lamal (1991), “uma característica da análise comportamental das sociedades é que ela é, fundamentalmente, descritiva, ao invés de experimental" (p.5). Este desafio tem norteado o refinamento contínuo dos procedimentos de estudo sobre metacontingência em laboratório, os quais frequentemente se diversificam entre analisar variáveis intervenientes em processos e macrocomportamentos, desenvolver análogos experimentais de fenômenos culturais, ou propor intervenções tecnológicas no comportamento social resultando em mudanças efetivas nas práticas culturais de um grupo. A Tabela 2 apresenta pesquisas experimentais de 2008 a 2015. 
Tabela 2. Estudos experimentais sobre metacontingências e macrocontingências entre 2008 e 2015.

\begin{tabular}{|c|c|}
\hline Autor / Ano & Influência Teórica / Experimental \\
\hline Baum, Richerson, Efferson, e Paciotti (2004) & $\begin{array}{l}\text { Microsociedades em laboratório e a } \\
\text { transmissão de regras entre gerações. }\end{array}$ \\
\hline Baia (2008) & \multirow{7}{*}{$\begin{array}{l}\text { Arranjos experimentais e quase-experimentais } \\
\text { baseados no conceito de metacontingências } \\
\text { propostos por Glenn }(1986,2004,2006) .\end{array}$} \\
\hline Martone (2008) & \\
\hline Sampaio (2008) & \\
\hline Vichi, Andery e Glenn (2009) & \\
\hline Tourinho e Vichi (2012) & \\
\hline Hunter (2012) & \\
\hline Franceschini, Samelo, Xavier e Hunziker (2012) & \\
\hline Vichi (2005) & \multirow{5}{*}{$\begin{array}{l}\text { Variações do procedimento de Wiggins } \\
\text { (1969) com atividades envolvendo escolhas } \\
\text { dos participantes por linhas em uma matriz. }\end{array}$} \\
\hline Martone (2008) & \\
\hline Leite (2009) & \\
\hline Lopes (2010) & \\
\hline Tadaiesky (2010) & \\
\hline Pereira (2008) & \multirow{9}{*}{$\begin{array}{c}\text { Procedimentos envolvendo tarefas com } \\
\text { inserção de números em espaços } \\
\text { determinados em uma tela de computador, } \\
\text { utilizando o software Meta. }\end{array}$} \\
\hline Bullerjhann (2009) & \\
\hline Caldas (2009) & \\
\hline Oda (2009) & \\
\hline Amorim (2010) & \\
\hline Gadelha (2010) & \\
\hline Vieira (2010) & \\
\hline Brocal (2010) & \\
\hline Dos Santos (2011) & \\
\hline D. C. Costa (2008) & \multirow{4}{*}{$\begin{array}{c}\text { Arranjos experimentais baseados no Jogo } \\
\text { Dilema do Prisioneiro, formulado por Dresher } \\
\text { e Flood (1950). }\end{array}$} \\
\hline C. P. V. Nogueira (2009) & \\
\hline Ortu, Becker, Woelz e Glenn (2012) & \\
\hline Costa, Nogueira e L. A. Vasconcelos (2012) & \\
\hline E. E. Nogueira (2010) & \multirow{3}{*}{$\begin{array}{l}\text { Variações no procedimento do Jogo Dilema } \\
\text { dos Comuns, desenvolvido por Hardin (1968). }\end{array}$} \\
\hline Silva (2011) & \\
\hline D. C. Costa (2013) & \\
\hline Borba, Tourinho e Glenn (2014) & \multirow{2}{*}{$\begin{array}{l}\text { Análise de macrocomportamentos e } \\
\text { macrocontingências. }\end{array}$} \\
\hline Borba, Silva, Cabral, Souza, Leite e Tourinho (2014) & \\
\hline $\begin{array}{l}\text { Baia, Azevedo, Segantini, Macedo e L. A. Vasconcelos } \\
\text { (2014) }\end{array}$ & $\begin{array}{c}\text { Análise das consequências individuais e } \\
\text { consequências culturais na seleção de } \\
\text { operantes e culturantes. }\end{array}$ \\
\hline Cavalcanti, Leite e Tourinho (2014) & $\begin{array}{l}\text { Seleção de práticas culturais através do } \\
\text { procedimento de aproximação sucessiva. }\end{array}$ \\
\hline $\begin{array}{c}\text { De Toledo, Benvenuti, Sampaio, Marques, Cabral, } \\
\text { Araujo, Machado e Moreira (2015) }\end{array}$ & $\begin{array}{l}\text { Experimento sobre seleção cultural utilizando } \\
\text { o software Free culturant. }\end{array}$ \\
\hline I. G. Vasconcelos (2014) & \multirow{2}{*}{$\begin{array}{l}\text { Experimentos sobre seleção cultural } \\
\text { utilizando o software } 2 \text { cavalos. }\end{array}$} \\
\hline Todorov e I. G. Vasconcelos (2015) & \\
\hline Azevedo (2015) & \multirow{2}{*}{$\begin{array}{l}\text { Experimentos sobre seleção cultural } \\
\text { utilizando o software Xadrez. }\end{array}$} \\
\hline Oliveira (2015) & \\
\hline
\end{tabular}


Vale ressaltar que o conceito de metacontingências não abrange uma explicação definitiva para os eventos sociais, e que outras ciências além da psicologia contribuem com análises culturais de diversos eventos sociais (Todorov, 2009, 2012). O termo seleção cultural deve ser considerado por analistas do comportamento em integração com a sociologia comportamental, a qual busca por aprimoramento conceitual e metodológico, seja a nível ontogenético (e.g., Bavelas, Hastorf, Gross \& Kite, 1965) ou cultural (e.g., Wiggins, 1969).

\section{Leis e o controle coletivo}

Leis estabelecem regras sociais com o objetivo de incentivar, inibir ou direcionar comportamentos (Skinner, 1953/2007; Todorov, 2005). Para Catania (1999) a maneira como os indivíduos se comportam depende em algumas situações diretamente do que foram instruídos a fazer; nesse contexto as regras descrevem contingências, sendo úteis em situações nas quais as consequências naturais são eficazes somente a longo prazo ou ineficientes a curto prazo. A lei como instrumento estabelecedor de regras possibilita que consequências remotas venham a controlar o comportamento, propiciando que os indivíduos ajam de forma deliberada com base nos repertórios culturais linguísticos comuns aos integrantes de um grupo (Skinner, 1969/1984; Matos, 2001).

Neste contexto social específico, Todorov et al. (2004) descreve que as metacontingências compõem a base da governança sobre os comportamentos de qualquer sociedade. Para Skinner (1969/1984, p.13) as "práticas culturais evoluem, mas também podem ser planejadas", por meio do estabelecimento de normas e regras que padronizam os limites de atuação individual, controlando o comportamento social em diferentes níveis e formas. Essas regras freqüentemente são estabelecidas por órgãos governamentais que são resultados da organização coletiva. 
Tragédias na sociedade também são resultantes de práticas culturais ou padrões de comportamento aprendidos e transmitidos socialmente, adotados em situações como no atentado às torres gêmeas em 2001, nos Estados Unidos, que resultou em outras tragédias sociais como a retaliação ao Afeganistão e a invasão do Iraque (Todorov et al., 2004). Skinner (1953/2007) afirma:

(...) Quando já tivermos descoberto as leis que governam uma parte do mundo ao nosso redor, e quando tivermos organizado estas leis em um sistema, estaremos então preparados para lidar eficientemente com esta parte do mundo. Ao prevermos a ocorrência de um acontecimento, somos capazes de nos preparar para ele. Dispondo as condições nos moldes especificados pelas leis de um sistema, não somente prevemos, mas também controlamos: 'causamos' que um acontecimento ocorra ou assuma certas características. (p.15)

Para Todorov (1987), entre os vários cenários sociais de utilização do conceito de metacontingência há um importante conjunto de pesquisas que se voltaram especificamente para a análise de leis com a premissa de que estas são compostas por contingências tríplices completas (estímulo antecedente, comportamento e consequência), e que uma vez entrelaçadas podem formar metacontingências que controlam ou modificam práticas sociais. Contingências descritas no texto da lei podem compor metacontingências envolvendo operadores da lei e membros da sociedade civil.

A nível cultural, contingências similares foram objetos de estudo - de forma pioneira - em dois trabalhos: 1) por Todorov (1987) ao utilizar o conceito de metcontingência para analisar a constituinte responsável pelo processo social de transição da ditadura para a democracia no Brasil, que resultaria na Constituição Federal de 1988 ; 2) $\mathrm{Na}$ análise funcional da legislação do Estatuto da Criança e do Adolescente - ECA (Todorov, Moreira, Prudêncio \& Pereira, 2004). A partir dessas pesquisas, conforme descrito na Tabela 3, outros analistas do comportamento desenvolveram trabalhos envolvendo leis como objeto de estudo, e metacontingências. 
Tabela 3. Análises de contingências e metacontingências em leis publicadas de 1987 à 2016.

\begin{tabular}{|c|c|}
\hline Autor (Ano) & Objeto de estudo \\
\hline Todorov (1987) & Constituinte \\
\hline Todorov, Moreira, Prudêncio e Pereira (2004) & Estatuto da Criança e do Adolescente - ECA \\
\hline Prudêncio (2006) & $\begin{array}{l}\text { O ECA sobre as práticas jurídicas em processos de } \\
\text { infração de adolescentes no Distrito Federal }\end{array}$ \\
\hline Pereira (2006) & $\begin{array}{l}\text { O ECA e o comportamento dos aplicadores e executores } \\
\text { da lei }\end{array}$ \\
\hline Dias, Passarelli, Vilaca e Carneiro (2006) & Legislação de Recursos Hídricos \\
\hline C. Z. Cabral (2007) & Estatuto da Pessoa com Deficiência \\
\hline A. L. A. Martins (2009) & Leis Orgânicas da Saúde — LOS \\
\hline Forero, García e López-López (2012) & Lei colombiana Ley de Justiça y Paz — LJP \\
\hline Naves (2013) & $\begin{array}{l}\text { Relações entre a mídia e leis nas mudanças da família } \\
\text { brasileira }\end{array}$ \\
\hline Carvalho (2014) & $\begin{array}{l}\text { Lei de Diretrizes e Bases da Educação Nacional - } \\
\text { LDB }\end{array}$ \\
\hline M. D. C. Cabral (2014) & Lei 12.433/11 que altera a Lei de Execução Penal \\
\hline T. G. Martins (2014) & $\begin{array}{l}\text { A Legislação de Educação Especial e a instituição de } \\
\text { Escolas Inclusivas }\end{array}$ \\
\hline Fava (2015) & $\begin{array}{l}\text { Comportamento das famílias beneficiárias do Programa } \\
\text { Bolsa Família }\end{array}$ \\
\hline
\end{tabular}

O estabelecimento de leis eficazes são mecanismos de intervenção e planejamento cultural, descritas por Skinner (1953/2007) como uma "regra de conduta no sentido de que especifica as consequências de certas ações que regem o comportamento" (p. 370). A razão para se intervir em comportamentos no nível cultural, advém da insatisfação com o produto gerado, e portanto é uma alternativa com validade social por parte do ambiente selecionador quando existe a insatisfação em relação ao produto agregado gerado pelo comportamento de inúmeras pessoas (Malott \& Glenn, 2006). 


\section{Desastres: A busca por macrocomportamentos de precaução e protetivos}

Desastres têm sido amplamente investigados a partir do século XX (Quarantelli \& Dynes, 1977; Dynes \& Drabek, 1994). De acordo com o Escritório das Nações Unidas para a Redução do Risco de Desastres - UNISDR, um desastre pode ser conceituado como:
(...) uma séria interrupção do funcionamento de uma comunidade ou sociedade, que causa perdas humanas e/ou importantes impactos ou perdas materiais, econômicas ou ambientais que excedem a capacidade da comunidade ou sociedade afetada de lidar com a situação utilizando seus próprios recursos. (UNISDR, 2009)

Castro (2004) descreve a representatividade de um desastre como o "resultado de eventos adversos, naturais ou provocados pelo homem sobre um ecossistema vulnerável, causando danos humanos, materiais ou ambientais e consequentes prejuízos econômicos e sociais" (p.47). Esses eventos naturais considerados como fenômenos sociais possuem variadas formas e envolvem essencialmente dois aspectos muito relevantes de uma população: 1) Vulnerabilidade social precedente e presente no espaço e 2) Pessoas afetadas, as quais não contam com condições ideais de reabilitação ou recuperação (Valêncio, 2010). Além dos fatores de magnitude e irregularidade do fenômeno (Tominaga, 2009), variáveis como o tempo e as circunstâncias de exposição das populações vulneráveis ao risco também são importantes para determinar a intensidade de um desastre, e o quão efetivo de uma cultura de prevenção e resposta em cenários de desastre ${ }^{1}$.

Spink (2014) descreve o surgimento de uma postura interpretativa mais sociológica dos agentes governamentais e civis envolvidos, designando desastres como um processo social complexo de várias dimensões, ao invés de considerar como um

\footnotetext{
1 Prefeitura de São Paulo/SP, Defesa Civil - Terminologia de Desastres. Disponível em:
} http://www.prefeitura.sp.gov.br/cidade/secretarias/subprefeituras/defesa_civil 
simples fenômeno resultante de eventos naturais externos. O conhecimento sobre tal fenômeno possibilita a hierarquização do risco, o fortalecimento ou aumento de práticas culturais recorrentes e protetivas entre as populações expostas ao risco de desastres.

Com base na evolução estatística dos registros acumulados mundialmente por centros avançados na área de gestão de riscos de desastres, estima-se que nos próximos 50 anos, o número e a gravidade desses eventos aumentem em torno de cinco vezes a proporção atual (Thomas \& Kopczak, 2005). Neste cenário, Brasiliano (2011) descreve a importância do conhecimento técnico sobre esses fenômenos cada vez mais presentes no contexto social, frequentemente classificados por sua evolução lenta ou rápida. Os desastres de evolução lenta acarretam grandes prejuízos em longo prazo, podendo agregar mais eventos catastróficos, como inundações graduais. Os desastres de evolução rápida destacam-se por sua magnitude e impactos em curto prazo, tais como escoamentos de detritos, terremotos, erupções vulcânicas, furacões e tsunamis (Kobiyama, Checchia, Silva, Schröder, Grando, \& Reginatto, 2004).

As mudanças climáticas no mundo durante o século XXI têm favorecido o aumento na frequência global dos desastres, tornando o tema mais presente na discussão e planejamento de políticas públicas dos países (Kuhn, Campbell-Lendrum, Haines, Cox, Corvalán \& Anker, 2005). Registros mundiais acumulativos da ONU em 20 anos $^{2}$ demonstram que as consequências reais dos desastres de origem natural ${ }^{3}$ não podem ser medidas apenas pela demografia das regiões afetadas, havendo outras variáveis complexas que interferem no dimensionamento do impacto desses fenômenos. Situações de países como Chile, afetado por tsunamis, terremotos e inundações

\footnotetext{
2 Relatório da ONU 'The Human Cost Of Weather Related Disasters (1995-2015)'. Disponível em: https://www.unisdr.org/we/inform/publications/46796

${ }^{3}$ Para Bodstein, De Lima, e De Barros (2014) a substituição cotidiana do termo "desastres naturais" por "desastres de origem natural ou de causas naturais" conforme adotado pela terminologia da ONU é mais adequado quando se avalia este fenômeno como uma situação de alta anormalidade, portanto, não poderia ser considerado como um evento natural.
} 
somaram mais de US\$ 3 bilhões em prejuízos econômicos e a Guatemala, aproximadamente 3 milhões de pessoas afetadas diretamente por desastres de deslizamentos de terra. Dados recentes apresentados pelo UNISDR em conjunto com o Centro de Pesquisas de Epidemiologia em Desastres - CRED ${ }^{4}$, afirmam que $90 \%$ dos desastres de causas naturais são originados da mudança climática, e o Brasil é o único das Américas na lista dos 10 países com maior número de pessoas afetadas por desastres até 2015. Destaques de agentes mundiais responsáveis pelo planejamento e preparação em relação a estes fenômenos é evidente:

Atravessamos o ano mais quente jamais registrado. Cerca de 98,6 milhões de pessoas se viram afetadas por desastres em 2015 e o clima, ajudado por um forte fenômeno de El Niño, foi um fator em 92\% dos casos. (...) As secas piorarão em 2016. Neste ano vamos enfrentar um desastre humanitário por esta razão, com êxodos de população e migrações. (...) Vários países da Europa enfrentaram limites de calor com números significativos de vítima mortais, sobretudo na França, enquanto Índia e Paquistão experimentaram ondas de calor que estiveram entre as mais graves dos últimos tempos. (...) A mortalidade pelas ondas de calor está muito subestimada. ${ }^{5}$

De acordo com Lucente e Manacez (1999), os registros formais de desastres no Brasil existem desde 1563, quando o Padre Eugênio Galdim relatou pela primeira vez as fortes secas do nordeste, cujas vítimas essencialmente eram os índios. A Secretaria Nacional de Proteção e Defesa Civil descreve o país com características peculiares de desastres de causas naturais distribuídas regionalmente, com predominância: Região Norte - incêndios florestais e inundações; Região Nordeste - secas e inundações; Região Centro-Oeste - desastres típicos de incêndios florestais; Região Sudeste -

\footnotetext{
${ }^{4}$ Release da ONU ' $U N$ report finds 90 per cent of disasters are weather-related' publicado em 23/11/2015. Disponível em: http://www.un.org/apps/news/story.asp?NewsId=52627\#.VyVmznpYC0j

${ }^{5}$ Entrevista com Robert Glasser (Diretor da UNISDR) e Debarati Guha-Sapir (Diretora do CRED), publicada em 11/02/2016. Disponível em: http://exame.abril.com.br/tecnologia/noticias/mudancaclimatica-esta-envolvida-em-9-de-cada-10-desastres
} 
deslizamento e inundações; Região Sul - inundações, vendavais e granizo (Brasil, 2014).

A região sudeste possui a maior frequência de desastres relacionados a tempestades, em grande parte resultante desses eventos como consequência do aquecimento global (Brasil, 2012). Segundo registros do CEPED (2011), no Brasil aproximadamente $60 \%$ dos desastres identificados são classificados de origem climáticas, com predominância da estiagem e da seca atingindo mais de 50 milhões de brasileiros.

No ranking mundial da $\mathrm{ONU}^{6}$, o Brasil está entre os países mais afetados por desastres de causas naturais, a exemplo dos deslizamentos de massa que resultam em elevados índices de mortes e populações atingidas. As inundações bruscas, classificadas como desastres geohidrometeorológicos, correspondem a aproximadamente $33 \%$ do total de eventos registrados, atingindo 39 milhões de pessoas (EM-DAT, 2014; Tominaga et al., 2009). Eventos desse tipo, comuns no Brasil, apresentam maior número de mortalidade e morbidade ${ }^{7}$ quando avaliado em termos de desastres com impacto direto sobre a população (CEPED, 2011), corroborando com um histórico de desastres de repercussão nacional conforme demonstrado abaixo na Tabela 4. Esse cenário contribuiu nos últimos anos para o avanço nos investimentos e adaptação tecnológica por parte do governo para diminuir o grau de vulnerabilidade e aumento na preparação e prevenção dessas cidades na gestão de riscos de desastres (Marengo, Valverde, \& Obregon, 2013).

\footnotetext{
${ }^{6}$ Relatório da ONU 'The Human Cost Of Weather Related Disasters (1995-2015)'. Disponível em: https://www.unisdr.org/we/inform/publications/46796

${ }^{7} \mathrm{O}$ termo morbidade ou morbilidade refere-se ao percentual de feridos em uma situação de desastre.
} 
Tabela 4. Lista dos desastres com grande repercussão no Brasil entre 1961 e 2015.

\begin{tabular}{|c|c|c|}
\hline ANO & CIDADE / ESTADO & DESASTRE \\
\hline 1961 & Niterói / RJ & $\begin{array}{l}\text { Incêndio no Gran Circus Norte-Americano, mais de } 500 \text { mortes } \\
(70 \% \text { de crianças })^{8} \text {. }\end{array}$ \\
\hline 1967 & Caraguatatuba / SP & $\begin{array}{l}\text { Fortes chuvas provocaram grandes enchentes, com } 436 \text { mortes. } \\
\mathrm{Na} \text { época, o maior registro de desastre de origem natural com } \\
\text { fatalidades no país } 9\end{array}$ \\
\hline 1984 & Cubatão / SP & $\begin{array}{l}\text { Vazamento em refinaria de gasolina, provocando mortes e } \\
\text { incêndio em mais de } 500 \text { moradias do Vilarejo São José }{ }^{10} \text {. }\end{array}$ \\
\hline 1987 & Goiânia / GO & $\begin{array}{l}\text { Contaminação da população com Césio-137, na época o } \\
\text { segundo maior acidente radioativo do mundo após Chernobyl } \\
\text { em } 1986^{11} \text {. }\end{array}$ \\
\hline 2008 & Santa Catarina & $\begin{array}{l}\text { Fortes chuvas e enchentes com alto índice de fatalidade, } \\
\text { devastação e grande mobilização da Defesa Civil nacional }{ }^{12} \text {. }\end{array}$ \\
\hline 2010 & $\begin{array}{l}\text { Alagoas e } \\
\text { Pernambuco }\end{array}$ & $\begin{array}{l}\text { Fortes enchentes em } 19 \text { municípios com mais de } 70 \text { mil } \\
\text { desabrigados e } 30 \text { mortes }^{13} \text {. }\end{array}$ \\
\hline 2010 & $\begin{array}{l}\text { Niterói / Rio de } \\
\text { Janeiro }\end{array}$ & $\begin{array}{l}\text { Deslizamentos de massa no Morro do Bumba, provocando } 48 \\
\text { mortes e o soterramento de centenas de casas }{ }^{14} \text {. }\end{array}$ \\
\hline 2011 & $\begin{array}{l}\text { Região Serrana / } \\
\text { Rio de Janeiro }\end{array}$ & $\begin{array}{l}\text { Fortes enchentes em } 7 \text { cidades. } 947 \text { mortes, mais de } 500 \\
\text { desaparecidos e milhares de desabrigados. Considerado na } \\
\text { época o maior desastre climático da história do país }{ }^{15} \text {. }\end{array}$ \\
\hline 2013 & Santa Maria / RS & Incêndio na boate Kiss, com 242 mortes e mais de 600 feridos. \\
\hline 2015 & Mariana / MG & $\begin{array}{l}\text { Rompimento da barragem da mineradora Samarco, provocando } \\
\text { avalanche de milhões de } \mathrm{m}^{3} \text { de lama e resíduos, atingindo } 2 \\
\text { estados e } 39 \text { cidades. O maior acidente no mundo em volume } \\
\text { de material despejado por barragens de rejeitos de mineração }{ }^{16} \text {. }\end{array}$ \\
\hline
\end{tabular}

Em duas décadas, o Brasil registrou acima de 31 mil desastres (cerca de 1.500 desastres por ano), afetando de forma direta e indireta a vida de 96 milhões de pessoas, desabrigando aproximadamente 300 mil pessoas por ano. Estes registros não

\footnotetext{
${ }^{8}$ Jornal A Tribuna/RJ - Publicado em 17/12/2011.

${ }^{9}$ Jornal Folha de São Paulo - Publicado em 13/01/2011.

${ }^{10}$ Couto (2003).

11 Jornal O Globo - Publicado em 13/09/2013.

${ }^{12}$ CREA SC — Publicado em 25/06/2013. Disponível em: http://www.crea-sc.org.br/portal/

${ }^{13}$ Jornal O Globo - Publicado em 19/06/2014.

${ }^{14}$ Jornal O Globo - Publicado em 06/04/2015.

${ }^{15}$ Dourado et al. (2012).

${ }^{16}$ Jornal O Globo - Publicado em 17/11/2015.
} 
contabilizam prejuízos humanos e materiais no médio e longo prazo, e refere-se apenas aos impactos de curto prazo ou aos primeiros períodos pós-desastre (CEPED, 2011).

Bases de escala global como EM-DAT (Emergency Events Database) são frequentemente utilizados pela ONU para nortear ações e políticas mundiais relacionadas ao gerenciamento de desastres. O conhecimento científico histórico no Brasil sobre a realidade brasileira de desastres de origem natural avançou a partir de 2012 com o surgimento de projetos específicos incentivados pela Secretaria Nacional de Defesa Civil como o Atlas Brasileiro de Desastres Naturais, o Sistema Integrado de Informações sobre Desastres - S2ID e o Diagnóstico do Plano Nacional de Gestão de Riscos e Resposta a Desastres - PNGRD. Para Skinner (1978):

A escolha é clara: ou não fazemos nada e permitimos que um futuro miserável e provavelmente catastrófico nos alcance, ou usamos nosso conhecimento sobre o comportamento humano para criar um ambiente social no qual poderemos viver vidas produtivas e criativas, e fazemos isso sem pôr em risco as chances de que aqueles que se seguirão a nós sejam capazes de fazer o mesmo. (p. 66)

Iniciativas experimentais realizadas por analistas do comportamento têm contribuído na compreensão dos desastres e em áreas relacionadas, como os efeitos da radiação sobre o responder dos organismos (e.g., Vasconcelos \& Gimenes, 1991, 1993; Vasconcelos, Gimenes, \& Todorov, 1993; Vasconcelos, 1999), desastres climáticos (e.g., Malott, 2010) e comportamentos protetivos de sustentabilidade ambiental (e.g., Twyman, 2010).

Para Bruck (2007), novas iniciativas científicas são válidas e devem fomentar envolvimento de várias teorias e tipos de habilidades quando se trata situações emergenciais envolvendo fatores de risco que podem resultar em altos índices de perdas materiais e humanas. A vulnerabilidade socioambiental e a resiliência são conceitos centrais para Spink (2014) em pesquisas relacionadas a desastres. Extremos de 
familiaridade ou de incerteza da concretização do desastre, onde a ameaça é muitas vezes culturalmente desconsiderada pela população e por órgãos governamentais, aumentam a vulnerabilidade e diminuem a resiliência para lidar com esse tipo de contexto. Para Bodstein, De Lima e De Barros (2014), a diminuição da vulnerabilidade e a formulação de uma cultura de prevenção ao risco abrange a preparação de grupos sociais específicos como os idosos, cujo declínio natural da sua capacidade funcional gera uma maior exposição a acidentes.

Essa vulnerabilidade transmitida como uma prática cultural pode ser interpretada a partir de Malott e Glenn (2006) por meio de CCEs que resultam em altos índices de perdas materiais e danos à segurança de muitos indivíduos diretamente e indiretamente envolvidos. Linhagens culturo-comportamentais devem, portanto, serem alteradas em diferentes metacontingências. Nesse cenário de prevenção de riscos de desastres, novas linhas operantes também são necessárias (O'Keefe, Westgate \& Wisner, 1976). Rodriguez, Quarantelli e Dynes (2007) mostram que o aumento da vulnerabilidade é uma tendência e as condições socioeconômicas serão as principais causas do agravamento de desastres. Os riscos de desastres são fenômenos socialmente construídos, podendo ser influenciados por estruturas sociais e políticas como: disponibilidade de recursos, estratificação e desigualdades entre os habitantes, crescimento da população, densidade, dispersão e degradação ambiental, entre outros. Esta complexa rede social que promove um comportamento vulnerável nos indivíduos é contemplada nas considerações sobre cultura, proposta por Skinner:

Geralmente fala-se de um ambiente social como a 'cultura' de um grupo. Muitas vezes se supõe que o termo se refira a um espírito ou atmosfera ou algo com dimensões igualmente nãofísicas. Nossa análise do ambiente social, entretanto, fornece uma explicação dos aspectos essenciais da cultura através de uma ciência natural. Permite-nos não apenas entender o efeito da cultura, mas alterar o planejamento cultural. No sentido mais 
amplo possível, a cultura na qual um indivíduo nasce se compõe de todas as variáveis que o afetam e que são dispostas por outras pessoas. O ambiente social em parte é o resultado daqueles procedimentos do grupo que geram o comportamento ético e a extensão desses procedimentos aos usos e costumes. (Skinner, 1953/2007, p.45)

\section{Defesa Civil e as Cidades Resilientes}

No contexto de intervenções nas práticas sociais relacionadas à prevenção e ao gerenciamento de desastres do ponto de vista governamental brasileiro, a Defesa Civil é definida como um "conjunto de ações preventivas, de socorro, assistenciais e recuperativas destinadas a evitar ou minimizar os desastres, preservar a moral da população e restabelecer a normalidade social” (Brasil, 2007, p. 9). Em uma perspectiva mais ampla, essas práticas de prevenção (defensivas) apresentam suas raízes históricas desde os primeiros grupos humanos dos quais se tem registros. Tais grupos utilizavamse desses recursos preventivos como ferramenta de sobrevivência coletiva, em uma atitude de proteção e superação frente a eventos naturais (Gomes Jr \& Alves, 2003).

O objetivo de normalidade social que permeia as ações de Defesa Civil no país baseia-se sistemicamente em ações que monitoram, preveem e agem sobre alterações da normalidade social como eventos denominados de desastres. Tais eventos são capazes de provocar profundas mudanças no cotidiano social, alterando o modo de vida e convívio entre as pessoas (Massing, Lise, \& Gaio, 2009). Associado a essa definição, os desastres devem ser percebidos como eventos que vão além de um simples acontecimento produzido pelas ações da natureza. Do ponto de vista da responsabilidade governamental, torna-se necessário fortalecer e estruturar instituições que atendam situações de anormalidade (Brasil, 2010; Freitas, \& De Campos, 2010). No Brasil o destaque para os socorros públicos já era previsto desde a primeira Constituição do Império, datada de 1824, permanecendo presente nas Cartas Magnas, ao longo dos 
próximos cem anos, até aproximadamente 1937 (Furtado, Oliveira, Dantas, Souza, \& Panceri, 2012).

Conforme registros do Ministério da Integração Nacional (2012), historicamente, a Inglaterra é mundialmente reconhecida como país pioneiro na instituição formal de uma Defesa Civil com objetivo de proteção e segurança da população. A estrutura criada pelos ingleses, conhecida como Civil Defense surgiu aproximadamente no período entre 1940 e 1941, em meio ao contexto da Segunda Guerra Mundial (1939-1945), quando o país foi alvo de inúmeros bombardeios, causando perdas em grande escala com a dizimação das principais cidades e mortes de milhares de civis ingleses. Seguindo o exemplo da Inglaterra, o Brasil em 1942 instituiu o Serviço de Defesa Passiva Antiaérea, após a pressão de movimentos populares sobre o governo para possível reação em resposta aos ataques de submarinos alemães no litoral da Bahia no mesmo ano. Em 1943, o governo brasileiro estabeleceu a nova nomenclatura para Serviço de Defesa Civil. Após três anos de vigência, em 1946 o Serviço de Defesa Civil foi extinto com toda sua estrutura de apoio. Na década de 1960, houve no Brasil várias iniciativas referentes à nova estruturação de uma defesa civil, com a mobilização de alguns estados do sudeste como Rio de Janeiro e São Paulo que foram vítimas de grandes enchentes.

Vale ressaltar que neste período o governo mudou o foco de proteção a possíveis desastres originados por guerras para atuação em desastres de causas naturais. Desta mobilização resultaram projetos de alto impacto como as Coordenadorias Regionais de Defesa Civil (REDEC), a primeira Defesa Civil Estadual, em 1966 no extinto Estado de Guanabara, hoje incorporado ao estado do Rio de Janeiro. O projeto de destaque foi a criação do Grupo Especial para Assuntos de Calamidades Públicas (GEACAP), cuja finalidade era dar assistência e proteção permanente contra calamidades que pudessem 
afetar a população. Este projeto criado em 1970 foi considerado de grande importância, pois preparou a base governamental para uma estruturação crescente. Assim, após 18 anos a Defesa Civil brasileira foi ampliada e se estabelece de maneira estratégica na atuação e prevenção de desastres a nível nacional por meio do Decreto $n^{\circ} 97.274$ de 16.12.1988 ${ }^{17}$, com a implantação do Sistema Nacional de Defesa Civil (SINDEC).

Através do Decreto Federal $n^{\mathrm{o}} 5.376^{18}$ de 17.02.2005 houve novas e importantes definições sobre a composição e operacionalidade do SINDEC, paralelo ao surgimento do Conselho Nacional de Defesa Civil - CONDEC, uma entidade com perspectiva consultiva, atendendo ao Art. 21, inciso XVIII da Constituição Federal ${ }^{19}$ que determina à União a responsabilidade de "planejar e promover a defesa permanente contra as calamidades públicas, especialmente as secas e as inundações”.

A Lei $n^{0} 12.608^{20}$ homolagada em 10 de abril de 2012, instituiu a Política Nacional de Proteção e Defesa Civil — PNPDEC. Essa política ampliou o escopo de atuação da Defesa Civil e teve como objetivo principal determinar regras sociais para vários níveis governamentais estabelecendo ações (comportamentos) esperados para cada agente nessa rede de contingências que envolviam a prevenção e atuação em desastres de origem natural no território brasileiro. O sistema de proteção e defesa civil proposto tinha como objetivo gerar produtos agregados (PAs) que transmitissem a sensação de segurança e a integridade para a população. Esta lei inova ao acrescentar na nomenclatura a referência da palavra proteção, cujo nome mudou para Sistema Nacional de Proteção e Defesa Civil - SINPDEC, alteração semelhante e igualmente aplicada no CONDEC que passou a se chamar Conselho Nacional de Proteção e Defesa Civil - CONPDEC (Lucente \& Manacez, 1999; Brasil, 2014). A inserção da Lei $n^{\circ}$

\footnotetext{
${ }^{17}$ Decreto disponível em: http://www.planalto.gov.br/ccivil_03/decreto/D97274.htm

${ }^{18}$ Decreto disponível em: http://www.planalto.gov.br/ccivil_03/_ato2004-2006/2005/Decreto/D5376.htm

${ }^{19}$ Constituição disponível em: http://www.planalto.gov.br/ccivil_03/Constituicao/Constituicao.htm

${ }^{20}$ Disponível em: http://www.planalto.gov.br/ccivil_03/_Ato2011-2014/2012/Lei/L12608.htm
} 
12.608/12 no contexto histórico das principais mudanças relacionadas à gestão governamental de riscos de desastres pode ser observado na Figura 1. 


\section{Criação da Defesa Civil, ONU ao Marco de Sendai 2015-2030}

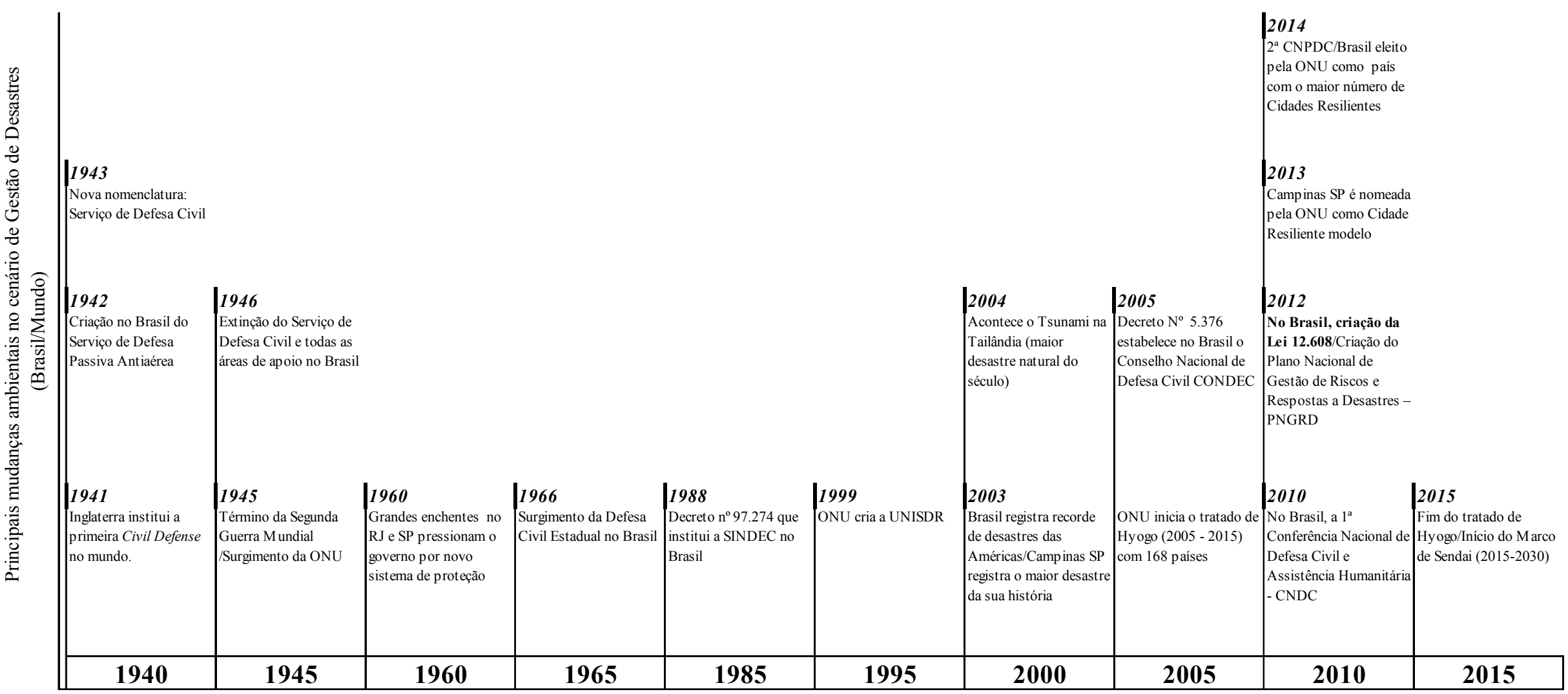

Quinquênios

Figura 1. Principais mudanças no contexto nacional e internacional na área de gestão de desastres em sete décadas. 
Realizar intervenções nas práticas culturais com o objetivo da prevenção de desastres faz parte de um contexto no qual diferentes áreas da psicologia apresentam contribuições relevantes, gerando novos caminhos para a política pública de Defesa Civil (Coêlho, 2010; Verona, 2011). A partir de 2014, o cenário tornou-se ainda mais favorável para essa contribuição face as discussões sobre importantes agendas globais pós-2015 que envolveram pesquisadores de diversas áreas do conhecimento em planejamentos mundiais como o estabelecimento dos Objetivos do Desenvolvimento Sustentável $(\mathrm{ODS})^{21}$ e novo cronograma internacional para gestão de desastres denominado de Marco de Ação Sendai (2015-2030) ${ }^{22}$, substituindo o Marco de Ação de Hyogo, encerrado em 2015.

Bruck (2007) descreve que estudos sobre pessoas em situações de anormalidades relacionadas a riscos de desastres geralmente envolvem comportamentos alvos da análise quanto as respostas que ocorrem antes, durante e após o evento crítico, demonstrando que as maneiras como as pessoas se comportam frente a essas situações revelam as suas respectivas condições atuais de vulnerabilidade. Há uma evolução sociológica dessa característica, descrita pelo termo vulnerabilidade social. Em uma avaliação inicial, o contexto de vulnerabilidade envolve basicamente três componentes: estar exposto ao risco, mostrar déficits em competências para o enfrentamento e ter dificuldade de adaptar-se diante do risco (Alves \& Torres, 2006).

Para Tomasini e Van Wassenhove (2009), existem quatro fases para o gerenciamento de desastres, que devem contemplar qualquer planejamento inclusive políticas governamentais, que correspondem a mitigação, preparação, resposta e recuperação. A Lei $\mathrm{n}^{\circ}$ 12.608/12 determina cinco fases para o mesmo gerenciamento:

\footnotetext{
${ }^{21}$ PNUD. Disponível em: http://www.pnud.org.br/ods.aspx

${ }^{22}$ UN World Conference on Disaster Risk Reduction. Disponível em: http://www.wcdrr.org/home
} 
prevenção, mitigação, preparação, resposta e recuperação. Estas fases previstas na legislação brasileira são descritas pela Defesa Civil de Curitiba/ $\mathrm{PR}^{23}$ como:

Prevenção - quando são realizados a orientação, educação e esclarecimentos à sociedade quanto às formas de se evitar possíveis desastres. Essa é a fase para qual deve ser dedicada maior atenção. Mitigação - é a diminuição ou a limitação dos impactos das ameaças e desastres. Como nem sempre é possível evitar os riscos de desastres e suas consequências, as tarefas preventivas acabam por se transformar em ações mitigatórias. Preparação - quando são realizadas as ações de planejamento, prevendo a metodologia de intervenção, capacitação das equipes e disponibilização da infraestrutura necessária para emprego se houver desastre, visando a minimizar os danos consequentes do evento. Essa fase é uma das mais importantes, pois define a qualidade da fase posterior. Resposta - fase em que, em razão de um desastre, é colocado em prática todo o planejamento para fazer frente aos efeitos negativos de um evento adverso numa área de risco (vulnerável). Recuperação - essa etapa é caracterizada por ser aquela em que são executados procedimentos para o restabelecimento da normalidade no local atingido por desastre. É quando o poder público e a sociedade, unidos, realizam obras estruturais reparadoras, reorganizam a rotina e reconstroem o que foi perdido, buscando o retorno da normalidade o mais rápido e da maneira menos traumática possível.

A Organização das Nações Unidas representa um agente internacional com grande influência sobre os planos e as ações compactuadas pelos países para tratarem de diversos assuntos de interesse social em nível mundial, entre eles as políticas de proteção e defesa civil adotadas pelos governos para lidar com situações de riscos de desastres de origem natural. Com a finalidade de aumentar o nível de incentivo governamental das nações e adaptação frente às mudanças naturais, a ONU em 1999 criou a UNISDR, um escritório com sede em Genebra, onde são desenvolvidos marcos e políticas mundiais de atuação social e ambiental, a serem implementados em parceria

23 Coordenadoria Municipal de Proteção e Defesa Civil de Curitiba/PR. Disponível em: http://www.defesacivil.curitiba.pr.gov.br 
com os governos dos países, em prol da proteção e desenvolvimento de suas respectivas comunidades.

Para aumentar a adesão dos países com mudanças políticas mais efetivas de desenvolvimento e gestão de riscos de desastres, a ONU estabelece as conferências mundiais que produzem os marcos globais a serem implementados em um período de 15 anos. O Marco de Ação de Hyogo (HFA) 2005-2015 surgiu para 'Construir resiliência das nações e comunidades frente aos desastres'. Estabelecido inicialmente com 168 nações e comunidades teve como destaque o aumento da resiliência na gestão dos riscos de desastres, estabelecendo como meta a redução de perdas humanas, econômicas e materiais. Esse acordo foi recebido pelos países como um guia abrangente que colaborava na ampliação das ações dos governos, órgãos, empresas, academia e todos os agentes da sociedade para uma integração de esforços na construção de cidades mais seguras e sustentáveis.

Em 2011 o governo brasileiro através do Ministério da Integração Nacional em parceria com a UNISDR/ONU estabeleceu formalmente a iniciativa de alcance nacional com a finalidade de aumentar o incentivo sobre as cidades no cumprimento das práticas de desenvolvimento sustentável em relação a desastres. O Marco de Hyogo previa o cumprimento de dez etapas, antes que uma cidade pudesse ser classificada como uma Cidade Resiliente a desastres ${ }^{24}$.

Nesta extensa e complexa rede de contingências entrelaçadas em uma política mundial de gerenciamento de riscos de desastres, a descentralização das iniciativas, da autoridade e dos recursos é um ponto chave de alteração das práticas culturais, que deveriam, na perspectiva da ONU, potencializar de forma efetiva e localmente a redução do risco. O tratado estabeleceu inicialmente alguns PAs como resultado do

\footnotetext{
24 Manual 'Construindo Cidades Resilientes', traduzido pela UNISDR. Disponível em: http://www.unisdr.org/files/26462_guiagestorespublicosweb.pdf
} 
trabalho interno dos países associados, chamados de 'cinco prioridades de ação' do HFA, descritos pela UNISDR (2012, p.12) como: 1) Construção da capacidade institucional; 2) Conhecer os próprios riscos; 3) Construir conhecimento e sensibilização; 4) Reduzir riscos; e 5) Estar preparado e pronto para agir.

A partir desses pilares, a Ação de Hyogo estabeleceu a campanha mundial denominada Cidades Resilientes. Esta campanha deu inicio a estruturação de ações em diversos países para diminuição da vulnerabilidade frente aos riscos de desastres. A UNISDR (2012, p. 11) descreve uma cidade como resiliente quando sua política governamental se estrutura em ações práticas que promovam a resiliência (resistência) e sustentabilidade em torno das ações de prevenção, mitigação, preparação, resposta e recuperação em situações de desastres.

Em 2014, o Brasil foi classificado pela ONU como país com o maior número de cidades resilientes do mundo, com 282 municípios participantes ${ }^{25}$. Para representantes da UNISDR as autoridades locais e a população devem compreender os riscos que enfrentam e desenvolver processos de informação local e compartilhada com base nos danos por desastres, ameaças e riscos. Um ponto importante nessa intervenção cultural da agência é o empoderamento dos cidadãos para participação, decisão e planejamento de sua cidade em conjunto com as autoridades locais. O Marco de Sendai para Redução do Risco de Desastres (2015-2030), tratado internacional vigente da ONU que estabeleceu a continuidade da campanha sobre Cidades Resilientes iniciada no marco de Hyogo, é fundamentado na meta central de restabelecer metacontingências e macrocomportamentos para manutenção das medidas adotadas na última década, que visam à redução de qualquer tipo de riscos e perdas de vidas.

${ }^{25}$ Governo Federal. Release publicado em 09/10/2014. Disponível em: http://www.brasil.gov.br/governo/2014/10/onu-aponta-brasil-como-pais-de-maior-numero-de-cidadesresilientes-no-mundo 
O sistema de Defesa Civil em cada nação tem um papel estratégico nessa proposta. Na perspectiva do Ministério da Integração Nacional (2010), historicamente a função da Defesa Civil em diversos países assumiu, incluindo Brasil, durante muitos anos um caráter assistencialista, em situações de socorro a populações vítimas de desastres. No entanto, no contexto contemporâneo há uma postura mais preventiva neste complexo sistema, e todos os agentes da área têm assumido a importância da integração do planejamento governamental com todos os agentes envolvidos (Brasil, 2012).

Este trabalho apresenta análises comportamentais de contingências e metacontingências presentes na Lei $\mathrm{n}^{\circ}$ 12.608/12, um importante instrumento jurídico governamental que determina as principais diretrizes, responsabilidades e interações no amplo e complexo sistema de defesa civil, juntamente com seus produtos agregados gerados para estabelecer a normalidade social e proteção da sociedade brasileira, diante do eminente risco de desastres. Este cenário descreve a importância e a justificativa do presente estudo. Desta forma, o objetivo geral deste trabalho consiste em analisar funcionalmente a Lei Federal $\mathrm{n}^{\circ}$ 12.608/12 a partir da abordagem teórica $\mathrm{e}$ metodológica da Análise do Comportamento em um contexto aplicado. Para tal, os objetivos específicos foram estruturados da seguinte forma: (1) Identificar as principais contingências e metacontingências presentes na Lei $n^{0} 12.608 / 12$, descrevendo seus componentes: contingências comportamentais entrelaçadas (CCEs), produtos agregados (PAs), consequências culturais (CCs) e o ambiente selecionador do sistema de Defesa Civil no gerenciamento de riscos de desastres; (2) Avaliar a Lei $n^{\circ} 12.608 / 12$ enquanto componente de uma metacontingência maior, estabelecida por um sistema que envolve a participação de órgãos internacionais; (3) Verificar a extensão da contribuição das metacontingências presentes na lei sobre a atuação do sistema de Defesa Civil em situações de prevenção e gerenciamento de desastres. 


\section{Método}

\section{Objeto de Estudo}

O método descritivo caracteriza a presente pesquisa, e estabelece como objeto de estudo a Lei Federal ${ }^{\circ}$ 12.608/12 decretada em 10 de abril de 2012. A lei divide-se em quatro principais eixos de mudanças no contexto legal e operacional no sistema de Defesa Civil brasileiro, órgãos e agentes relacionados, sendo: 1) Instituição da Política Nacional de Proteção e Defesa Civil (PNPDEC); 2) Disposição do Sistema Nacional de Proteção e Defesa Civil (SINPDEC) e do Conselho Nacional de Proteção e Defesa Civil (CONPDEC); 3) Autorização para criação de sistema de informações e monitoramento para fenômenos de desastres; 4) Intervenção e alteração em outras legislações: Lei $n^{0}$ 12.340 de $1^{\circ}$ de dezembro de 2010, Lei $n^{\circ} 10.257$ de 10 de julho de 2001, Lei $\mathrm{n}^{\mathrm{o}} 6.766$ de 19 de dezembro de 1979, Lei $\mathrm{n}^{\circ} 8.239$ de 4 de outubro de 1991, e Lei $\mathrm{n}^{\circ}$ 9.394, de 20 de dezembro de 1996. O objeto dessa pesquisa apresenta a seguinte composição estrutural conforme a Tabela 5.

Tabela 5. Estrutura da Lei $n^{\circ}$ 12.608/12.

\begin{tabular}{cc}
\hline Elementos & Quantidade \\
\hline Capítulos & 4 \\
\hline Seções & 4 \\
\hline Artigos & 31 \\
\hline Parágrafos & 13 \\
\hline Incisos & 81 \\
\hline Páginas & 13 \\
\hline Termos (palavras) & 4.676 \\
\hline
\end{tabular}




\section{Fontes Documentais}

Foram estabelecidos para sustentação teórica e analítica como fontes de pesquisa desse estudo:

- A Lei Federal $\mathrm{n}^{\mathrm{o}} 12.608 / 12$, disponibilizada através do acervo digital do Governo Federal e fisicamente na Biblioteca Nacional em Brasília/DF.

- Informações coletadas durante a $2^{\mathrm{a}}$ Conferência Nacional de Proteção e Defesa Civil, realizada no período de 04 a 07 de novembro de 2014, na cidade de Brasília/DF. O evento resultou em 10 Princípios e 30 Diretrizes com sugestões de mudança baseadas na Lei $\mathrm{n}^{\circ} 12.608 / 12$.

- Documentos e publicações oficiais disponibilizados fisicamente e digitalmente pelo Ministério da Integração Nacional (MI) e órgãos governamentais relacionados através dos seus canais de contato e divulgação ao público.

- Base de dados da Biblioteca do Ministério da Integração Nacional, sede dos arquivos e registros físicos da Defesa Civil brasileira, localizada no endereço: Ministério da Integração Nacional, Módulo F, Bloco A, SGAN 906, Asa Norte, Brasília/DF.

- Bases de publicações digitais acadêmicas científicas nacionais e internacionais da Psicologia e áreas afins (e.g., APA PsycNET, ABAI, JABA, SciELO, CAPES, LILACS, PePSIC, UnB).

- Bases de dados digitais específicas sobre Desastres: Escritório das Nações Unidas para a Redução do Risco de Desastres (UNISDR); Centro Regional de Informação sobre Desastres para América Latina e Caribe (CRID); Centro Universitário de Estudos e Pesquisas sobre Desastres (CEPED); Sistema Integrado de Informações sobre Desastres (S2ID). 


\section{Procedimentos}

A análise da Lei $\mathrm{n}^{\circ}$ 12.608/12 seguiu o modelo de análise funcional de contingências e metacontingências em leis desenvolvido por Todorov (ver Todorov, 1987, 2005; Todorov, Moreira, Prudêncio \& Pereira, 2004). Em Todorov et al. (2004) desenvolveu-se um estudo analítico-comportamental do Estatuto da Criança e do Adolescente (ECA), uma legislação que descreve contingências entrelaçadas de vários grupos na sociedade com consequências culturais de proteção de crianças e adolescentes. O procedimento de Todorov et al. (2004) teve como objetivo identificar as contingências tríplices entrelaçadas (antecedentes, comportamentos e consequências) descritas nos artigos do estatuto. Estas foram classificadas em completas quando possuíam três termos da contingência, ou incompletas descreviam apenas um ou dois termos da contingência. Ainda nesse estudo os autores buscaram identificar as metacontingências presentes no ECA.

A partir dos objetivos específicos propostos, a presente pesquisa com a análise da Lei $\mathrm{n}^{\circ} 12.608 / 12$ foi estruturada em seis fases, que descrevem: (1) As principais metacontingências formadas por contingências comportamentais (Eventos Antecedentes - Ações - Consequências), identificando eventos antecedentes (contexto no qual o comportamento é emitido), os comportamentos (ações dos indivíduos) e as consequências (mudanças, punições e reforços produzidos pela interação do indivíduo com o ambiente influenciando a probabilidade futura de emissão do comportamento). As contingências foram classificadas como incompletas quando se identificou a ausência de um ou mais elementos da contingência de três termos. (2) As metacontingências definidas pelo entrelaçamento de contingências (CCEs) e os produtos sociais (PAs) resultantes (CCEs $\rightarrow$ PAs), os culturantes foram descritos com a consequência cultural selecionadora (CCEs $\rightarrow$ PAs $\rightarrow$ CSQ Cultural). (3) Interações da 
Lei $\mathrm{n}^{\circ} 12.608 / 12$ com outras leis. (4) Síntese dos 31 artigos da Lei $\mathrm{n}^{\circ}$ 12.608/12 e a identificação de agentes nas CCEs. (5) Análise descritiva sobre a composição textual da lei, com base na frequência de repetição de termos-chaves. (6) Descrição do cenário governamental brasileiro de gestão de riscos de desastres, identificando PAs, CCs, e o ambiente selecionador a partir da Lei $\mathrm{n}^{\circ}$ 12.608/12.

Ao término da análise funcional, a organização dos resultados permitiu analisar qual a extensão da contribuição das metacontingências presentes na lei sobre a atuação do sistema de Defesa Civil em situações de prevenção e gerenciamento de desastres, se há possíveis lacunas na composição de tais metacontingências, e de que forma seus respectivos produtos agregados interferem nas práticas culturais que se referem a proteção da população civil brasileira. Esta análise comportamental tem como objetivo ampliar a discussão sobre uma efetiva implementação do instrumento jurídico no contexto da gestão de riscos de desastres. 


\section{Resultados}

\section{Fases 1 e 2 - Identificação das principais contingências e metacontingências} presentes no texto da lei, respectivamente. ${ }^{26}$

O capítulo I com $6 \%$ do total de 31 de artigos presentes na Lei $\mathrm{n}^{\circ} 12.608 / 12$ estabelece direcionamentos fundamentais para os entes da Federação. A principal metacontingência presente na referida lei é descrita como: “(...) É dever da União, dos Estados, do Distrito Federal e dos Municípios adotar as medidas necessárias à redução dos riscos de desastre" (Art. $2^{\circ}$ ). Inicialmente identifica-se que o objetivo final da presente lei é articular medidas que estabeleçam uma classe de comportamentos operantes entre União, Estados e Municípios (CCEs) que resultem no comportamento alvo de reduzir os riscos de desastres (PA). No mesmo capítulo, este artigo está acompanhado dos parágrafos $\S 1^{\circ}$ “As medidas previstas no caput poderão ser adotadas com a colaboração de entidades públicas ou privadas e da sociedade em geral”, e $\S 2^{\circ}$ "A incerteza quanto ao risco de desastre não constituirá óbice para a adoção das medidas preventivas e mitigadoras da situação de risco" estabelecem o ambiente geral de aplicação da lei, porém quando tais elementos são analisados por meio da contingência tríplice observa-se a ausência das consequências (CCs), reforçadoras ou punitivas em casos do não cumprimento das ações esperadas pelos órgãos e agentes responsáveis a quem a lei se direciona, conforme demonstrado na Tabela 6.

\footnotetext{
${ }^{26}$ Todos os grifos em trechos das leis foram acrescentados pelo autor com o objetivo de destaque nas análises desenvolvidas.
} 
Tabela 6. Análise da principal metacontingência presente no Capítulo I da Lei $n^{\circ}$ 12.608/12.

\begin{tabular}{cccc}
\hline $\begin{array}{c}\text { Lei } \mathbf{n}^{\circ} \\
\mathbf{1 2 . 6 0 8} / \mathbf{1 2}\end{array}$ & $\begin{array}{c}\text { Contexto } \\
\text { (CCEs) }\end{array}$ & $\begin{array}{c}\text { Produtos } \\
\text { (PAs) }\end{array}$ & $\begin{array}{c}\text { Consequências } \\
\text { (CCs) }\end{array}$ \\
\hline \multirow{2}{*}{ Art. 2 $^{\circ}$} & $\begin{array}{c}\text { É dever da União, dos Estados, do } \\
\text { Distrito Federal e dos Municípios } \\
\text { adotar as medidas necessárias à }\end{array}$ & $\begin{array}{c}\text { redução dos riscos de } \\
\text { desastre. }\end{array}$ & (não definida) \\
\hline
\end{tabular}

Ainda no Art. $2^{\circ}$, os parágrafos $\S 1^{\circ}$ e $\S 2^{\circ}$ abrem a possibilidade de cooperação de agentes não responsabilizados diretamente pela lei como empresas privadas e sociedade, para aumentar a eficiência do sistema de proteção da defesa civil em situações onde não houver certeza quanto ao risco a desastre. As ações existentes no referido artigo descrevem, do ponto de vista funcional, uma medida de controle sobre as contingências entrelaçadas na principal metacontingência da lei, de maneira que as medidas previstas não podem ser tornar óbices (obstáculos) para que os agentes envolvidos adotem ações de prevenção (avaliação dos riscos) e mitigação (redução de causas e consequências na ocorrência de desastres). Essa flexibilidade na legislação aumenta a abrangência de agentes envolvidos na metacontingência do sistema de gerenciamento de riscos de desastres, ampliando a diversidade de CCEs envolvidas e consequentemente a complexidade do sistema.

A metacontingência é incompleta ao não prever no texto da lei consequências (CCs) seja para o cumprimento ou não cumprimento das ações previstas. A metacontingência da Tabela 6 envolve agentes representando municípios, estados e a união, e ainda, membros de outras entidades públicas, privadas e da sociedade civil. Portanto, metacontingências são identificadas - há um trabalho que exige entrelaçamento (CCEs), considerando que o produto social alvo (produto agregado, PA — redução de mortes; de riscos para a integridade física e psicológica em zonas de riscos de desastres; de perdas de patrimônio público; de perdas econômicas geradas neste conjunto de efeitos adversos). Esses PAs não podem ser obtidos apenas por um 
grupo de agentes, mas por todas as partes envolvidas 'stakeholders' como previsto no Marco de Sendai para Redução de Riscos de Desastres 2015-2030. E, consequências culturais (CCs) externas dispostas pela mídia e pela ONU selecionam esses macrocomportamentos - práticas culturais recorrentes. As CCs poderiam também ser dispostas por um sistema regulador ou deliberativo, o qual fortaleceria ou enfraqueceria práticas culturais adotadas, conforme previsto em parte nas características do CONPDEC. Os PAs podem também selecionar tais ações de todas as partes envolvidas, conforme Figura 2.

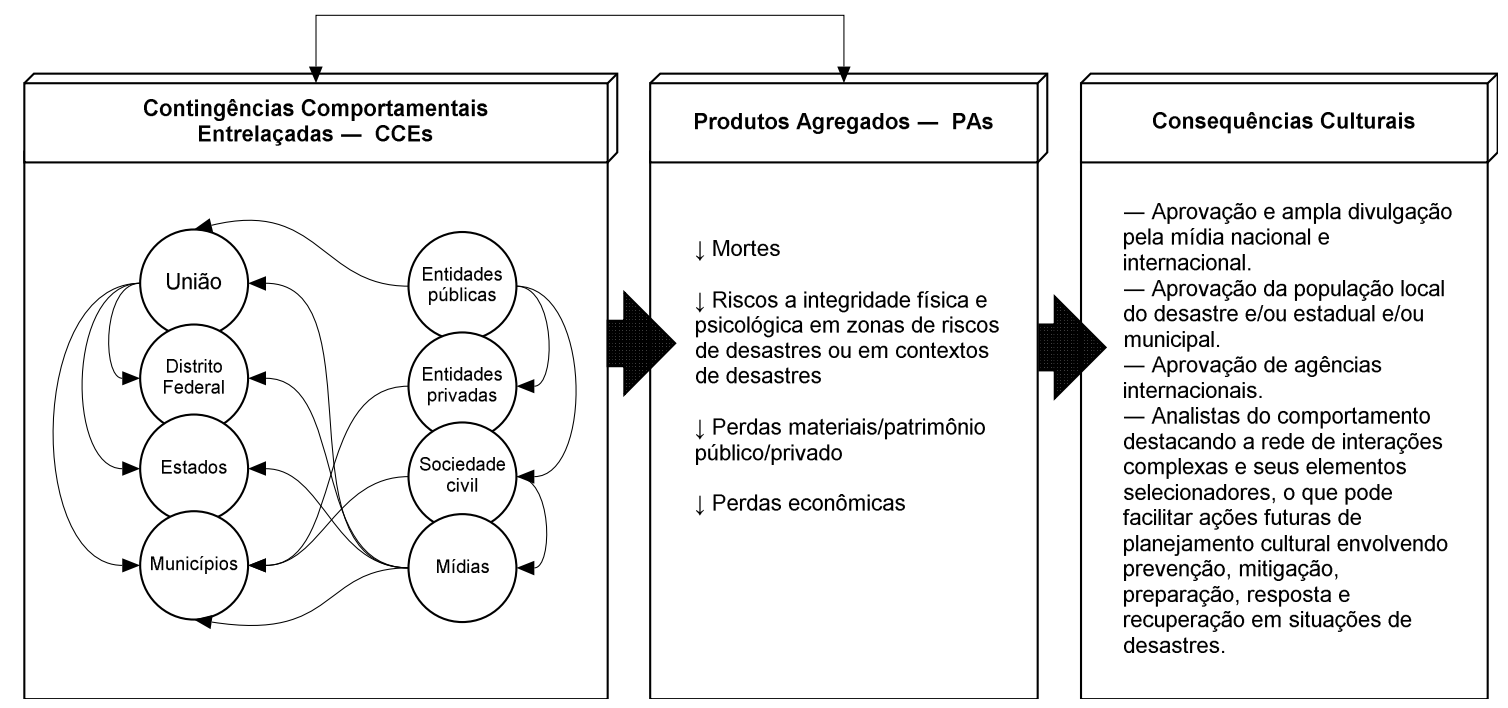

Figura 2. Metacontingências previstas no Capítulo I da Lei nº 12.608/12.

O capítulo II abrange $23 \%$ do total de 31 de artigos presentes na Lei $n^{\circ}$ 12.608/12. Duas seções descrevem a Política Nacional de Proteção e Defesa Civil PNPDEC, que representa o principal produto agregado gerado pela lei. O capítulo se desdobra em diretrizes, objetivos e delimitação quanto as responsabilidades individuais e coletivas dos agentes públicos a nível Federal (União), Estadual e Municipal. Quanto a dimensão desse produto agregado, o Art. $3^{\circ}$ descreve uma metacontingência incompleta: “(...) A PNPDEC abrange as ações de prevenção, mitigação, preparação, 
resposta e recuperação voltadas à proteção e defesa civil". Entretanto, as consequências em potencial podem ser esperadas por meio da mídia, especialistas e outros setores, ou líderes de órgãos governamentais. Os elementos das ações que representam os pilares da Defesa Civil (prevenção, mitigação, preparação, resposta e recuperação) são representados nos artigos $4^{\circ}$ e $5^{\circ}$ (que tratam respectivamente das diretrizes e objetivos) em 21 ações esperadas entre os agentes públicos, conforme descrito a seguir, e apresentado na Figura 3:

Art. $4^{\circ}$ São diretrizes da PNPDEC:

I - atuação articulada entre a União, os Estados, o Distrito Federal e os Municípios para redução de desastres e apoio às comunidades atingidas;

II - abordagem sistêmica das ações de prevenção, mitigação, preparação, resposta e recuperação;

III - a prioridade às ações preventivas relacionadas à minimização de desastres;

IV - adoção da bacia hidrográfica como unidade de análise das ações de prevenção de desastres relacionados a corpos d'água;

$\mathrm{V}$ - planejamento com base em pesquisas e estudos sobre áreas de risco e incidência de desastres no território nacional;

VI - participação da sociedade civil.

Art. $5^{\circ}$ São objetivos da PNPDEC:

I - reduzir os riscos de desastres;

II - prestar socorro e assistência às populações atingidas por desastres;

III - recuperar as áreas afetadas por desastres;

IV - incorporar a redução do risco de desastre e as ações de proteção e defesa civil entre os elementos da gestão territorial e do planejamento das políticas setoriais;

$\mathrm{V}$ - promover a continuidade das ações de proteção e defesa civil;

VI - estimular o desenvolvimento de cidades resilientes e os processos sustentáveis de urbanização;

VII - promover a identificação e avaliação das ameaças, suscetibilidades e vulnerabilidades a desastres, de modo a evitar ou reduzir sua ocorrência;

VIII - monitorar os eventos meteorológicos, hidrológicos, geológicos, biológicos, nucleares, químicos e outros potencialmente causadores de desastres;

IX - produzir alertas antecipados sobre a possibilidade de ocorrência de desastres naturais;

$X$ - estimular o ordenamento da ocupação do solo urbano e rural, tendo em vista sua conservação e a proteção da vegetação nativa, dos recursos hídricos e da vida humana;

XI - combater a ocupação de áreas ambientalmente vulneráveis e de risco e promover a realocação da população residente nessas áreas;

XII - estimular iniciativas que resultem na destinação de moradia em local seguro;

XIII - desenvolver consciência nacional acerca dos riscos de desastre;

XIV - orientar as comunidades a adotar comportamentos adequados de prevenção e de resposta em situação de desastre e promover a autoproteção; e

XV - integrar informações em sistema capaz de subsidiar os órgãos do SINPDEC na previsão e no controle dos efeitos negativos de eventos adversos sobre a população, os bens e serviços e o meio ambiente. 


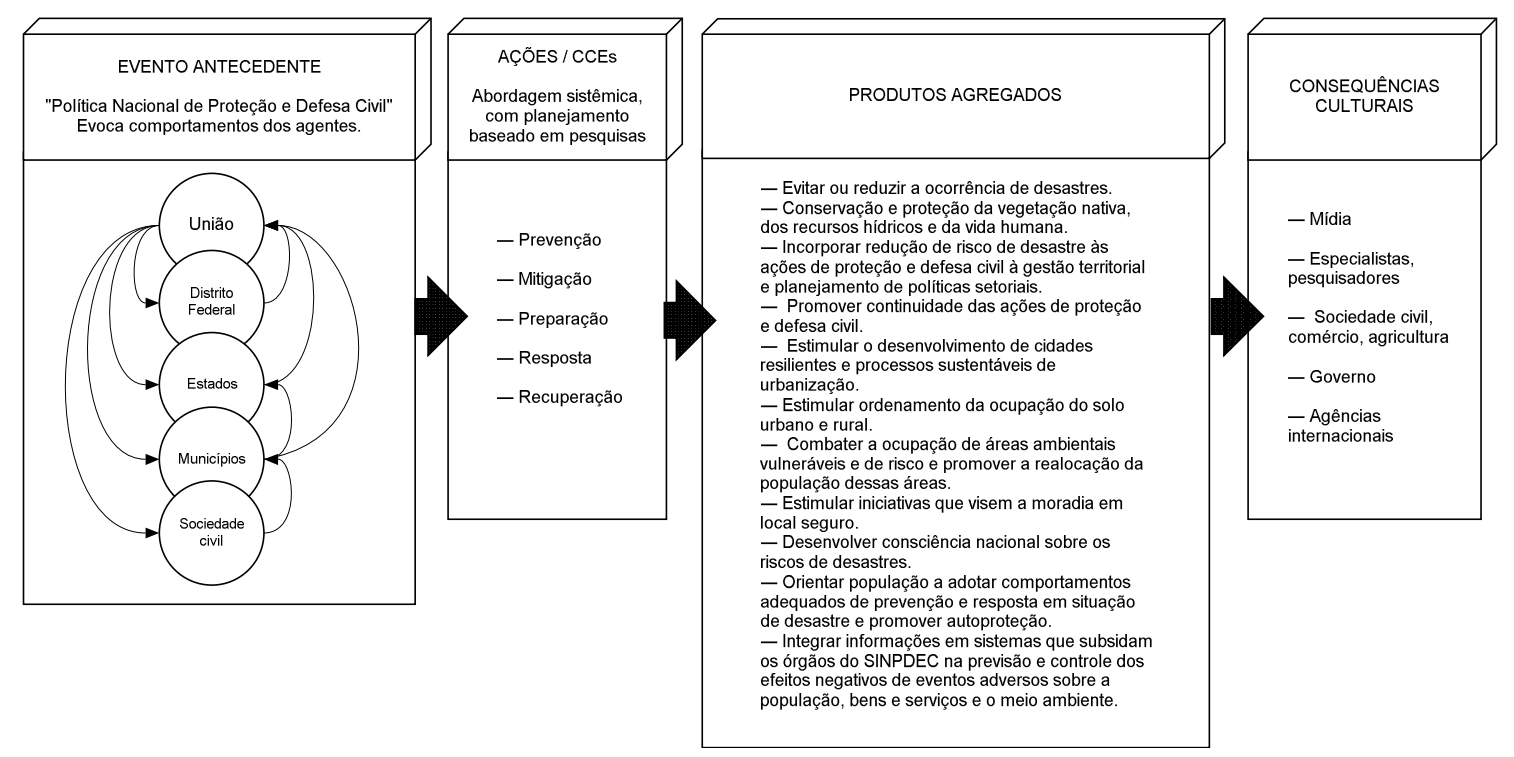

Figura 3. Metacontingências previstas no Capítulo II sobre a Política Nacional de Proteção e Defesa Civil.

Sobre o sistema governamental, o Art. $9^{\circ}$ estabelece a forma como os órgãos públicos devem interagir entre si e qual o resultado dessa interação nos incisos I, II, III, IV, V e VI, cada qual representando uma ação (comportamento ou produto). Todos os incisos apresentam metacontingências incompletas com ausência de consequências no texto da Lei $\mathrm{n}^{\circ}$ 12.608/12. Nos demais incisos desse artigo, há ausência de consequências diretas, que reforcem ou punam tais comportamentos, conforme descrito na Tabela 7.

Tabela 7. Responsabilidades compartilhadas entre os três níveis governamentais na Lei $n^{\circ}$ 12.608/12.

\begin{tabular}{|c|c|c|c|}
\hline $\begin{array}{c}\text { Lei } n^{\circ} \\
12.608 / 12\end{array}$ & $\begin{array}{l}\text { Contexto } \\
\text { (CCEs) }\end{array}$ & $\begin{array}{l}\text { Produtos } \\
\text { (PAs) }\end{array}$ & $\begin{array}{c}\text { Consequências } \\
\text { (CCs) }\end{array}$ \\
\hline \multirow{2}{*}{ Art. $9^{\circ}$} & $\begin{array}{l}\text { É dever da } \\
\text { União, dos } \\
\text { Estados, do }\end{array}$ & $\begin{array}{c}\text { "I - desenvolver cultura nacional de } \\
\text { prevenção de desastres, destinada ao } \\
\underline{\text { desenvolvimento da consciência }} \\
\underline{\text { nacional acerca dos riscos de desastre }} \\
\text { no País; }\end{array}$ & (não definida) \\
\hline & $\begin{array}{l}\text { Distrito Federal } \\
\text { e dos } \\
\text { Municípios }\end{array}$ & $\begin{array}{c}\text { II - estimular comportamentos de } \\
\text { prevenção capazes de evitar ou } \\
\text { minimizar a ocorrência de desastres; }\end{array}$ & (não definida) \\
\hline
\end{tabular}




\begin{tabular}{|c|c|c|c|}
\hline $\begin{array}{c}\text { Lei } n^{\circ} \\
12.608 / 12\end{array}$ & $\begin{array}{l}\text { Contexto } \\
\text { (CCEs) }\end{array}$ & $\begin{array}{l}\text { Produtos } \\
\text { (PAs) }\end{array}$ & $\begin{array}{c}\text { Consequências } \\
\text { (CCs) }\end{array}$ \\
\hline \multirow{4}{*}{ Art. $9^{\circ}$} & \multirow{4}{*}{$\begin{array}{c}\text { É dever da } \\
\text { União, dos } \\
\text { Estados, do } \\
\text { Distrito Federal } \\
\text { e dos } \\
\text { Municípios }\end{array}$} & $\begin{array}{c}\text { III - estimular a reorganização do } \\
\text { setor produtivo e a reestruturação } \\
\text { econômica das áreas atingidas por } \\
\text { desastres; }\end{array}$ & (não definida) \\
\hline & & $\begin{array}{c}\text { IV - estabelecer medidas preventivas } \\
\text { de segurança contra desastres em } \\
\text { escolas e hospitais situados em áreas } \\
\text { de risco; }\end{array}$ & (não definida) \\
\hline & & $\begin{array}{c}\mathrm{V} \text { - oferecer capacitação de recursos } \\
\text { humanos para as ações de proteção e } \\
\text { defesa civil; e }\end{array}$ & (não definida) \\
\hline & & $\begin{array}{l}\text { VI - fornecer dados e informações } \\
\text { para o sistema nacional de } \\
\text { informações e monitoramento de } \\
\text { desastres. }\end{array}$ & (não definida) \\
\hline
\end{tabular}

O capítulo III representa $10 \%$ do total de 31 de artigos presentes na Lei ${ }^{\circ}$ 12.608/12. Ele determina dois componentes básicos da Política Nacional de Proteção e Defesa Civil, que são o Sistema Nacional de Proteção e Defesa Civil (SINPDEC) e o Conselho Nacional de Proteção e Defesa Civil (CONPDEC).

A constituição do SINPDEC é representada no $\operatorname{Art}^{\circ} 10$ por “(...) órgãos e entidades da administração pública federal, dos Estados, do Distrito Federal e dos Municípios e pelas entidades públicas e privadas de atuação significativa na área de proteção e defesa civil.”. Outros agentes podem compor esse sistema, conforme Parágrafo Único - Art. 11: "Poderão participar do SINPDEC as organizações comunitárias de caráter voluntário ou outras entidades com atuação significativa nas ações locais de proteção e defesa civil’. Sua finalidade dentro do sistema nacional de gerenciamento de desastres é definida como “(...) contribuir no processo de planejamento, articulação, coordenação e execução dos programas, projetos e ações de proteção e defesa civil." (Art. 10, Parágrafo único). As metacontingências desse sistema são apresentadas na Figura 4. 


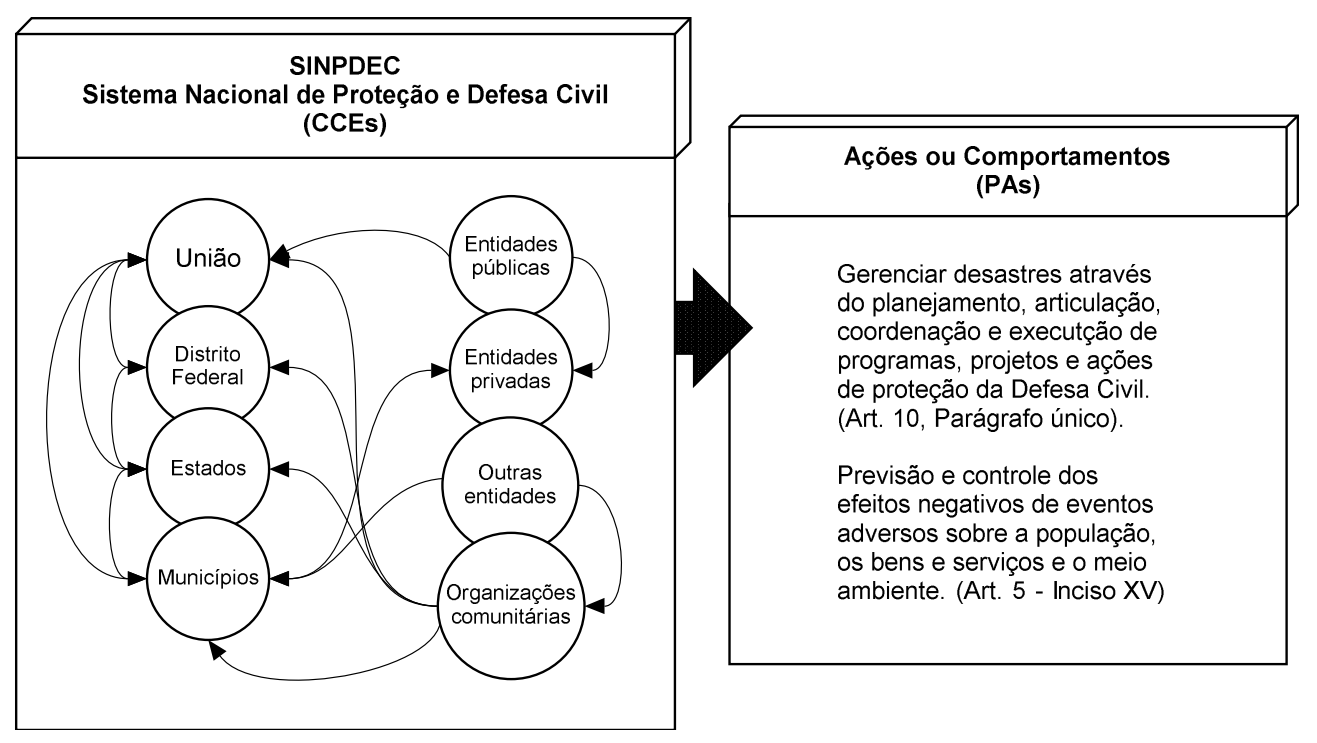

Figura 4. Metacontingências incompletas previstas no Capítulo III sobre o Sistema Nacional de Proteção e Defesa Civil.

O CONPDEC tem sua descrição e finalidade principal enumerados no Art. 12: “O CONPDEC, órgão colegiado integrante do Ministério da Integração Nacional, terá por finalidades: I - auxiliar na formulação, implementação e execução do Plano Nacional de Proteção e Defesa Civil". No mesmo artigo, os incisos II, III, IV e V representam as finalidades complementares do CONPDEC, que são desdobramentos das três principais ações de formular, implementar e executar o PNPDEC. Esse órgão, que exerce papel estratégico no PNPDEC também é composto, de órgãos setoriais dos três entes da Federação; podendo ser incluídos nesse complexo entrelaçamento outros agentes como descrito no Parágrafo $2^{\circ}$ do mesmo artigo: “O CONPDEC contará com representantes da União, dos Estados, do Distrito Federal, dos Municípios e da $\underline{\text { sociedade civil organizada, }}$ incluindo-se representantes das comunidades atingidas por desastre, e por especialistas de notório saber". As metacontingências desse sistema são apresentadas na Figura 5. 


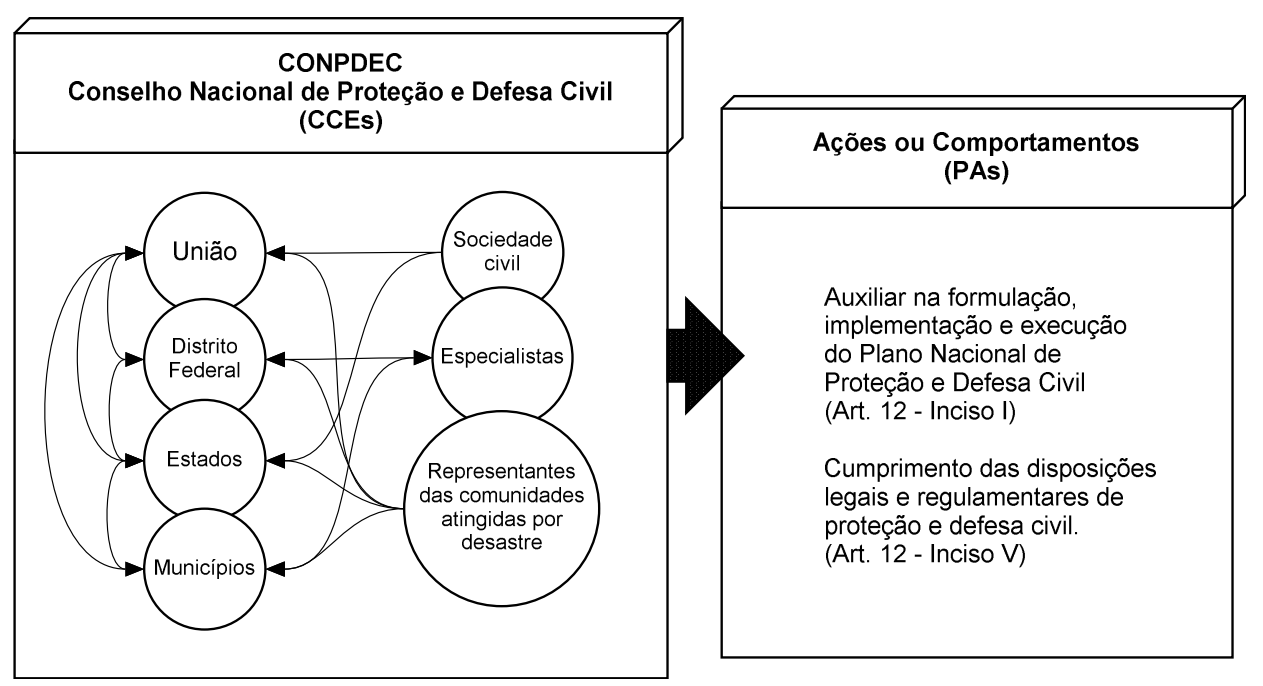

Figura 5. Metacontingências incompletas previstas no Capítulo III sobre o Conselho Nacional de Proteção e Defesa Civil.

\section{Fase 3 - Interações da Lei $n^{0} 12.608 / 12$ com outras leis.}

O capítulo IV abrange a maior porcentagem de artigos da referida lei com $61 \%$ do total de 31 de artigos. Finalmente, neste, são descritos grande parte das ações operacionais do sistema de defesa civil e de transferência - através da mediação do SINPDEC - dos recursos disponibilizados pela União ao Distrito Federal, Estados e Municípios para execução de ações de resposta e recuperação nas áreas atingidas por desastres (Art. 20), conforme mostra a Figura 6.

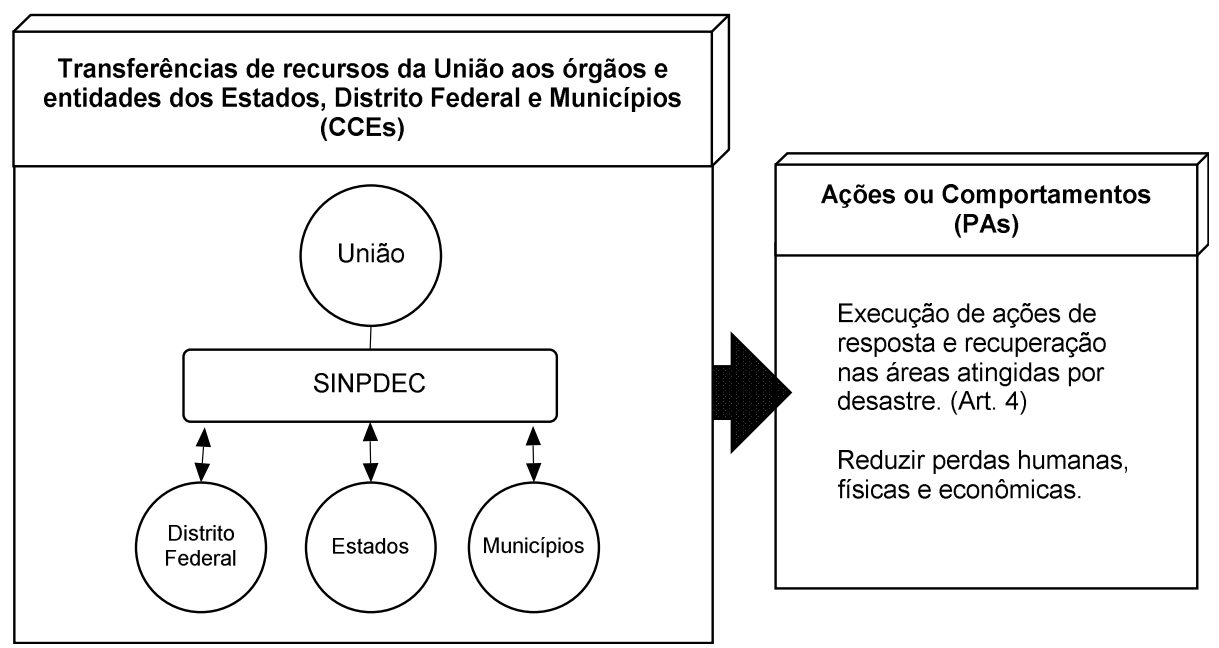

Figura 6. Metacontingências incompletas previstas no Capítulo IV sobre a transferência de recursos da União para os agentes do sistema de Defesa Civil. 
Ao analisar a estrutura e composição da Lei 12.608/12, identifica-se que 47\% dos artigos presentes neste capítulo (ou $29 \%$ de toda a Lei ${ }^{\circ} 12.608 / 12$ ) referem-se a alterações em outras leis correlacionadas. Especificamente cinco leis recebem alterações diretas da Lei $\mathrm{n}^{\circ} 12.608 / 12^{27}$, conforme ilustrado na Figura 7 , que descreve o foco central de cada lei alterada, a quantidade de menções e pontos de alterações da lei alterada por meio do texto da Lei ${ }^{\circ} 12.608 / 12$.

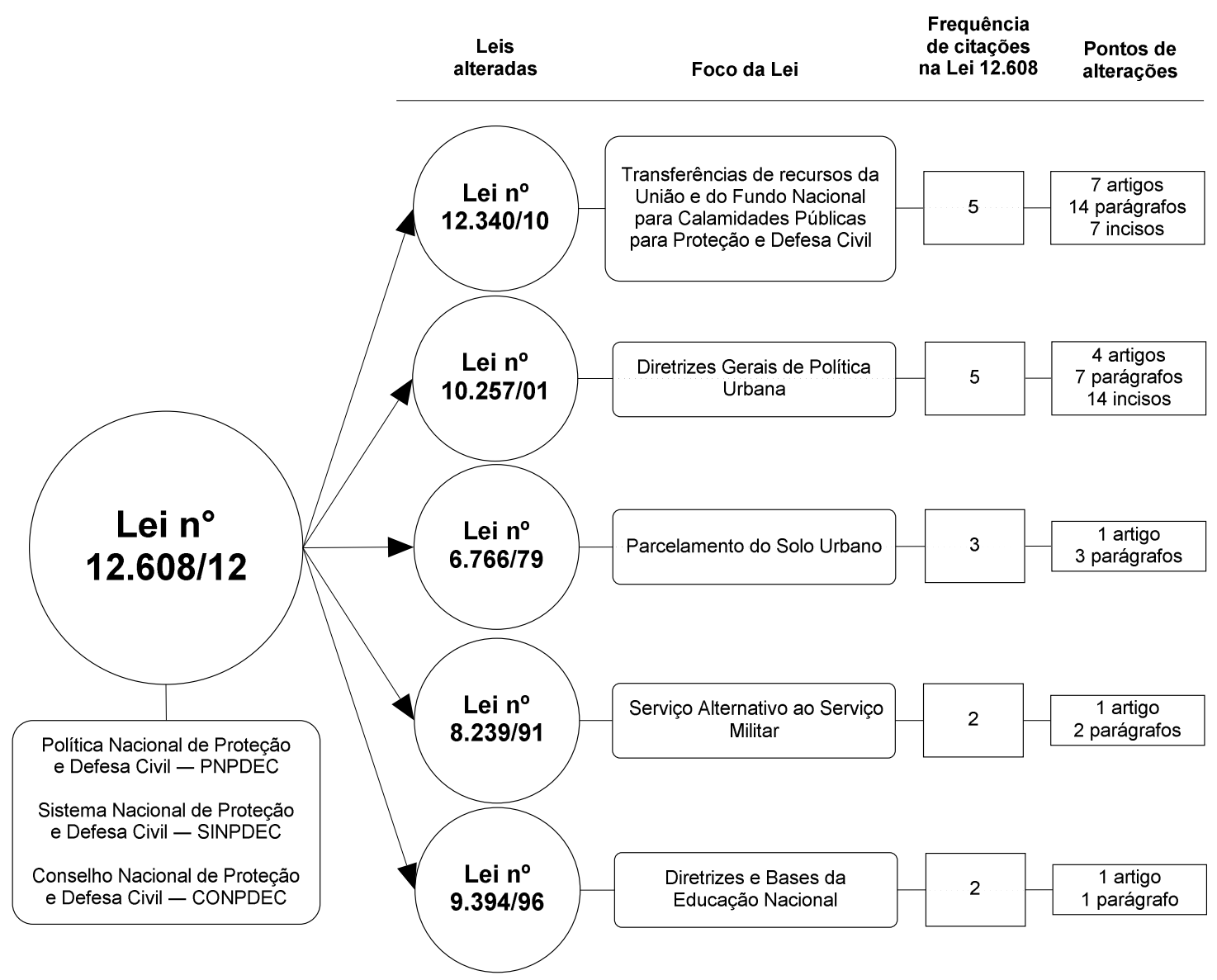

Figura 7. Intervenção da Lei $\mathrm{n}^{\circ} 12.608 / 12$ sobre outras cinco leis brasileiras ${ }^{28}$.

\footnotetext{
${ }^{27}$ A Lei 9.433/97, que regulamenta a Política Nacional de Recursos Hídricos, é mencionada no Art. 26 (mas não tem seu texto original alterado, por isso não está inclusa na Figura 7). Barros e Barros (2009) destacam a importância dessa lei no cenário brasileiro de gestão de desastres, argumentando que "as maiores perdas humanas e materiais no país estão ligadas à falta (estiagens) ou excesso (enchentes) de água" (p.2).

${ }^{28} \mathrm{Na}$ Figura 7, as leis foram ordenadas pelo critério de maior frequência de citações na Lei 12.608/12.
} 
A Lei $\mathbf{n}^{\circ} \mathbf{1 2 . 3 4 0}$ de $1^{\circ}$ de dezembro de 2010 recebe o maior número de intervenções, sendo mencionada respectivamente nos Artigos 20, 21, 22, 30 da Lei $n^{\circ}$ 12.608/12. Em seu texto original publicado em 2010, foram apresentados dois objetivos: 1) fazer novas disposições sobre o Sistema Nacional de Defesa Civil (SINDEC) e 2) tratar da transferência de recursos da União e do Fundo Especial para Calamidades Públicas, estruturação da defesa civil e atendimento aos estados e municípios em ocorrência de desastres. A Lei $\mathrm{n}^{\circ}$ 12.340/10 teve três alterações significativas: $\left(1^{\mathrm{a}}\right)$ Em 2012 com a Lei ${ }^{\circ}$ 12.608/12, alterou o SINDEC para SINPDEC; $\left(2^{\mathrm{a}}\right)$ Direcionou a lei original $\mathrm{n}^{\circ} 12.340 / 10$ para ater-se apenas à transferência de recursos públicos para o gerenciamento e prevenção de desastres, conforme Art. 20:

A ementa da Lei $\mathrm{n}^{\circ} 12.340$, de $1^{\circ}$ de dezembro de 2010, passa a vigorar com a seguinte redação: 'Dispõe sobre as transferências de recursos da União aos órgãos e entidades dos Estados, Distrito Federal e Municípios para a execução de ações de resposta e recuperação nas áreas atingidas por desastre, e sobre o Fundo Especial para Calamidades Públicas; e dá outras providências'.

E, (3 $3^{a}$ em 2014, com a Medida Provisória nº31/13 convertida posteriormente para a Lei 12.983/14 com o novo termo 'Proteção e Defesa Civil'. Na Lei n¹2.340/10 há o estabelecimento de metacontingências para a estruturação e operacionalização de um sistema governamental de proteção a desastres, partindo do pressuposto que em todas as fases de planejamento, antes e após a ocorrência de desastres, os estados e municípios precisam realizar determinados procedimentos burocráticos legais (estabelecidos através das leis e medidas provisórias), que condicionam o recebimento do apoio financeiro e estrutural da União. A Tabela 8 mostra a análise das metacontingências em três pontos específicos de alteração sobre a Lei $\mathrm{n}^{\circ}$ 12.340/10, com destaque para a operacionalização do sistema quanto ao repasse de recursos entre União e os agentes beneficiários (Estados e Municípios), na gestão de riscos de 
desastres. Novamente, observou-se a ausência de consequências diretas, no texto da legislação, que condicionem o cumprimento ou não cumprimento das ações previstas.

Tabela 8. Intervenções na Lei $n^{\circ} 12.340 / 10$.

\begin{tabular}{|c|c|c|c|}
\hline $\begin{array}{c}\text { Lei } \mathrm{n}^{\circ} \\
12.608 / 12\end{array}$ & $\begin{array}{l}\text { Contexto } \\
\text { (CCEs) }\end{array}$ & $\begin{array}{l}\text { Produtos } \\
\text { (PAs) }\end{array}$ & $\begin{array}{c}\text { Consequências } \\
\text { (CCs) }\end{array}$ \\
\hline \multirow[t]{3}{*}{ Art. 21} & $\begin{array}{l}\text { Os arts. } 4^{\circ} \text { e } 5^{\circ} \text { da } \\
\text { Lei no } 12.340, \text { de } \\
1^{\circ} \text { de dezembro } \\
\text { de } 2010 \text {, passam } \\
\text { a vigorar com a } \\
\text { seguinte redação: }\end{array}$ & $\begin{array}{l}\text { Art. } 4^{\circ} \text { São obrigatórias as transferências da União } \\
\text { aos órgãos e entidades dos Estados, do Distrito } \\
\text { Federal e dos Municípios para a execução de ações } \\
\text { de resposta e recuperação, observados os requisitos } \\
\text { e procedimentos previstos nesta Lei. }\end{array}$ & (não definida) \\
\hline & $\begin{array}{l}\begin{array}{c}\text { (...) no prazo } \\
\text { máximo de } 90 \\
\text { (noventa) dias da }\end{array} \\
\begin{array}{c}\text { ocorrência do } \\
\text { desastre. }\end{array}\end{array}$ & $\begin{array}{c}\S 2^{\circ} \text { No caso de execução de ações de recuperação, } \\
\text { o ente beneficiário deverá apresentar plano de } \\
\text { trabalho ao órgão central do SINPDEC (...) }\end{array}$ & (não definida) \\
\hline & $\begin{array}{l}\text { (...) sempre que } \\
\text { solicitado (...) }\end{array}$ & $\begin{array}{c}\S 3^{\circ} \text { Os entes beneficiários manterão, pelo prazo de } \\
5 \text { (cinco) anos, contados da data de aprovação da } \\
\text { prestação de contas que trata o } \S 2^{\circ} \text {, os documentos } \\
\text { a ela referentes, inclusive os comprovantes de } \\
\text { pagamentos efetuados com os recursos financeiros } \\
\text { transferidos na forma desta Lei, ficando obrigados a } \\
\text { disponibilizá-los, (...), ao órgão central do } \\
\text { SINPDEC, ao Tribunal de Contas da União e ao } \\
\text { Sistema de Controle Interno do Poder Executivo } \\
\text { federal. }\end{array}$ & (não definida) \\
\hline
\end{tabular}

A primeira alteração do Art. $4^{\circ}$ da Lei $n^{\circ} 12.340$ descreve a obrigatoriedade da União em relação aos repasses de recursos aos beneficiários, e estes têm o recebimento destes recursos condicionados à obrigatoriamente ao cumprimento das condições: 1) apresentar seu plano de trabalho em obras de recuperação de desastres em um prazo de até 90 dias e, 2) dispor de todos os documentos, comprovantes e planos referentes ao recebimento e uso dos recursos recebidos pela União, no prazo de até 5 anos. Na contingência que estabelece os critérios dessa interação entre as partes, os elementos antecedentes e os comportamentos esperados estão presentes em forma de prazos 
estipulados para que cada ação aconteça, no entanto, é inexistente a consequência direta para os Estados e Municípios quanto ao não cumprimento de tais regras.

Na segunda alteração, o Art. $3^{\circ}$ da Lei 12.340/10 estabelece o Cadastro Nacional de Municípios com áreas suscetíveis à ocorrência de desastres. Dessa forma, a União amplia o controle sobre o desenvolvimento dos municípios e a preparação dos mesmos quanto ao planejamento para gerenciamento de riscos de desastres. A composição dessa metacontingência demonstra-se incompleta, ao não apresentar consequências esperadas para o não cumprimento, conforme mostra a Tabela 9.

Tabela 9. Intervenções da Lei $n^{\circ} 12.608 / 12$ sobre o Cadastro Nacional de Municípios com áreas suscetíveis à ocorrência de desastres, previsto na Lei $n^{\circ} 12.340 / 10$.

\begin{tabular}{|c|c|c|c|}
\hline $\begin{array}{c}\text { Lei } n^{\circ} \\
12.608 / 12\end{array}$ & $\begin{array}{c}\text { Contexto } \\
\text { (CCEs) }\end{array}$ & $\begin{array}{l}\text { Produtos } \\
\text { (PAs) }\end{array}$ & $\begin{array}{c}\text { Consequências } \\
\text { (CCs) }\end{array}$ \\
\hline Art.22 & $\begin{array}{c}\text { A Lei } \mathrm{n}^{\circ} 12.340, \text { de } 1^{\circ} \text { de } \\
\text { dezembro de } 2010 \text {, passa a } \\
\text { vigorar acrescida dos seguintes } \\
\text { arts. } 3^{\circ}-\mathrm{A}, 3^{\circ} \text {-B e } 5^{\circ} \text {-A: } \\
\text { Art. } 3^{\circ} \text {-A. O Governo Federal } \\
\text { instituirá cadastro nacional de } \\
\text { municípios com áreas } \\
\text { suscetíveis à ocorrência de } \\
\text { deslizamentos de grande } \\
\text { impacto, inundações bruscas ou } \\
\text { processos geológicos ou } \\
\text { hidrológicos correlatos, } \\
\text { conforme regulamento. }\end{array}$ & $\begin{array}{l}\S 1^{\circ} \mathrm{A} \text { inscrição no cadastro } \\
\text { previsto no caput dar-se-á por } \\
\text { iniciativa do Município ou } \\
\text { mediante indicação dos demais } \\
\text { entes federados, observados os } \\
\text { critérios e procedimentos previstos } \\
\text { em regulamento. }\end{array}$ & (não definida) \\
\hline
\end{tabular}

Sem consequências diretas para a abstenção na realização da inscrição no cadastro nacional, há interferência direta sobre a mobilização dos municípios na elaboração do Plano de Contingência de Proteção e Defesa Civil. Este plano, conforme apresentado no Inciso II, do $\S 2^{\circ}$, Art. 22, torna-se obrigatório apenas aos municípios cadastrados no sistema nacional. Na terceira alteração, o Art. 22 da Lei n ${ }^{\circ}$ 12.608/12 que modifica o Art. $5^{\circ}$ da Lei $\mathrm{n}^{\circ} 12.340 / 10$ e estabelece determinantes para $\mathrm{a}$ 
operacionalização do sistema de proteção e defesa civil, criando uma contingência de punição em situações do comportamento não ético dos beneficiários estados e municípios. Conforme a seguir:

Art. $5^{\circ}$ - A. Constatada, a qualquer tempo, a presença de vícios nos documentos apresentados, ou a inexistência do estado de calamidade pública ou da situação de emergência declarados, o ato administrativo que tenha autorizado a realização da transferência obrigatória perderá seus efeitos, ficando o ente beneficiário obrigado a devolver os valores repassados, devidamente atualizados.

A consequência descrita nesse artigo restringe a devolução por parte dos beneficiários, dos valores financeiros atualizados para a União de forma não contingente aos casos de descumprimento de prazos governamentais estabelecidos na lei, como previsto por exemplo no Art. 21 citado anteriormente. Outros mecanismos jurídicos asseguram consequências punitivas mais amplas para contextos semelhantes, a exemplo da Lei $\mathrm{n}^{\circ}$ 8.429/92 que regulamenta situações de improbidade administrativa, responsabilizando agentes públicos em situações de danos ao recurso público durante a administração ${ }^{29}$. Nesses casos, o agente público pode ser punido com sanções que variam desde a perda de patrimônio obtido ilicitamente, até a perda da função pública com multa.

A segunda e a terceira leis do conjunto de cinco leis alteradas pela Lei $n^{\circ}$ 12.608/12 são a Lei $\mathbf{n}^{\mathbf{0}} \mathbf{1 0 . 2 5 7}$ de 10 de julho de 2001 e a Lei $\mathbf{n}^{\mathbf{0}} \mathbf{6 . 7 6 6}$ de 19 de dezembro de 1979, as quais tratam do planejamento e das políticas urbanas no uso e ordenamento do solo, aprovação de projetos de loteamento e desmembramento. Essas políticas descrevem o mapeamento prévio das áreas de risco suscetíveis a desastre e ao cumprimento do chamado Plano Diretor. Tais políticas contribuem diretamente no objetivo do PNPDEC em prevenir e mitigar, evitando ao máximo a exposição da

\footnotetext{
${ }^{29}$ A Lei n $8.429 / 92$ não é citada na Figura 7 porque não sofreu alteração da lei em análise.
} 
população a riscos de desastres. A principal metacontingência alterada na Lei $n^{0} 10.257$ é descrita abaixo na Tabela 10, e se mostra incompleta contendo apenas dois componentes da contigência tríplice: o contexto e a resposta esperada, neste caso pelos municípios integrantes do sistema nacional.

Tabela 10. Intervenção na Lei $n^{\circ} 10.257 / 01$.

\begin{tabular}{cccc}
\hline $\begin{array}{c}\text { Lei n } \\
\text { 12.608/12 }\end{array}$ & $\begin{array}{c}\text { Contexto } \\
\text { (CCEs) }\end{array}$ & $\begin{array}{c}\text { Produtos } \\
\text { (PAs) }\end{array}$ & $\begin{array}{c}\text { Consequências } \\
\text { (CCs) }\end{array}$ \\
\hline & $\begin{array}{c}\text { A Lei n }{ }^{\circ} \text { 10.257, de 10 de julho de } \\
\text { 2001, passa a vigorar acrescida dos } \\
\text { seguintes arts. 42-A e 42-B: }\end{array}$ & \\
Art.21 & $\begin{array}{c}\text { Art. 42-A. § } 4^{\text {o }} \text { Os Municípios } \\
\text { enquadrados no inciso VI do art. 41 }\end{array}$ & $\begin{array}{c}\text { aprovação pela Câmara } \\
\text { Municipal. }\end{array}$ & (não definida) \\
& $\begin{array}{c}\text { desta Lei e que não tenham Plano } \\
\text { Diretor aprovado terão o prazo de 5 } \\
\text { (cinco) anos para (...) }\end{array}$ & & \\
\hline
\end{tabular}

As duas últimas leis que sofreram alteração são a Lei $n^{\circ} 8.239 / 91$ e a Lei $n^{\circ}$ 9.394/96 (ver Figura 7). A Lei $\mathbf{n}^{\circ} \mathbf{8 . 2 3 9} / \mathbf{9 1}$ de 4 de outubro de 1991, articula sobre o treinamento dos serviços alternativos militares estabelecendo a metacontingência de participação deste agente em situações de desastre, categorizada na Constituição Federal como Serviços Alternativos Militares. A metacontingência alterada na referida lei é descrita no Art. 28, conforme Tabela 11. O não cumprimento desse artigo não prevê consequências na Lei $\mathrm{n}^{\circ} 12.608 / 12$, no entanto, há consequências previstas que complementam essa metacontingência, identificadas no texto original da lei alterada, conforme demonstra a Tabela 11 . 
Tabela 11. Intervenção na Lei $n^{\circ} 8.239 / 91$.

\begin{tabular}{|c|c|c|c|}
\hline $\begin{array}{c}\text { Lei } n^{\circ} \\
12.608 / 12\end{array}$ & $\begin{array}{l}\text { Contexto } \\
\text { (CCEs) }\end{array}$ & $\begin{array}{l}\text { Produtos } \\
\text { (PAs) }\end{array}$ & $\begin{array}{l}\text { Consequências } \\
\text { (CCs) }\end{array}$ \\
\hline Art.28 & $\begin{array}{c}\text { O art. } 3^{\circ} \text { da Lei } n^{\circ} 8.239, \\
\text { de } 4 \text { de outubro de } 1991, \\
\text { que regulamenta os } \S \S 1^{\circ} \\
\text { e } 2^{\circ} \text { do art. } 143 \mathrm{da} \\
\text { Constituição Federal, que } \\
\text { dispõem sobre a } \\
\text { prestação de Serviço } \\
\underline{\text { Alternativo ao Serviço }} \\
\underline{\text { Militar Obrigatório, }} \\
\text { passa a vigorar acrescido } \\
\text { dos seguintes } \S \S 4^{\circ} \text { e } 5^{\circ}:\end{array}$ & $\begin{array}{c}\text { “Art. } 3^{\circ}-\S 4^{\circ} \text { O Serviço } \\
\text { Alternativo incluirá o } \\
\text { treinamento para atuação em } \\
\text { áreas atingidas por desastre, } \\
\text { em situação de emergência e } \\
\text { estado de calamidade, } \\
\text { executado de forma } \\
\underline{\text { integrada com o órgão }} \\
\underline{\text { federal responsável pela }} \\
\text { implantação das ações de } \\
\text { proteção e defesa civil. }\end{array}$ & $\begin{array}{c}\text { (Não previsto na Lei } n^{\circ} 12.608 . \\
\text { mas identificada na } \\
\text { Lei } n^{\circ} 8.239, \text { Art. } 3, \S 1^{\circ} \text { ): } \\
\text { “A recusa ou cumprimento } \\
\text { incompleto do Serviço } \\
\text { Alternativo, sob qualquer } \\
\text { pretexto, por motivo de } \\
\text { responsabilidade pessoal do } \\
\text { convocado, implicará o não- } \\
\text { fornecimento do certificado } \\
\text { correspondente*, pelo prazo de } \\
\text { dois anos após o vencimento do } \\
\text { periodo estabelecido." }\end{array}$ \\
\hline
\end{tabular}

* Certificado de Prestação Alternativa ao Serviço Militar obrigatório, que possui o mesmo efeito jurídico do Certificado de Reservista.

E, a Lei no 9.394/96, de 20 de dezembro de 1996, que refere-se às diretrizes e bases da educação nacional, intervêm nos currículos do ensino fundamental e médio. Essa intervenção caracteriza um ponto importante para cumprimento da metacontingência estabelecida no Art. $9^{\circ}$ - inciso I: "desenvolver cultura nacional de prevenção de desastres, destinada ao desenvolvimento da consciência nacional acerca dos riscos de desastre no País". Uma metacontingência incompleta foi identificada no Art. 29, conforme demonstra a Tabela 12. Não foram identificadas nas leis correlatas possíveis consequências que completassem esta lacuna na metacontingência.

Tabela 12. Intervenção na Lei $n^{\circ} 9.394 / 96$.

\begin{tabular}{|c|c|c|c|}
\hline $\begin{array}{c}\text { Lei } n^{\circ} \\
12.608 / 12\end{array}$ & $\begin{array}{l}\text { Contexto } \\
\text { (CCEs) }\end{array}$ & $\begin{array}{l}\text { Produtos } \\
\text { (PAs) }\end{array}$ & $\begin{array}{c}\text { Consequências } \\
\text { (CCs) }\end{array}$ \\
\hline Art.29 & $\begin{array}{l}\text { O art. } 26 \text { da Lei } n^{\circ} 9.394 \text {, de } 20 \text { de } \\
\text { dezembro de } 1996 \text {, que estabelece } \\
\text { as diretrizes e bases da educação } \\
\underline{\text { nacional, passa a vigorar acrescido }} \\
\text { do seguinte } \S 7^{\circ} \text { : }\end{array}$ & $\begin{array}{l}\text { "Art. 26. } \S 7^{\circ} \text { Os currículos do } \\
\text { ensino fundamental e médio } \\
\underline{\text { devem incluir os princípios da }} \\
\text { proteção e defesa civil e a } \\
\text { educação ambiental de forma } \\
\text { integrada aos conteúdos } \\
\text { obrigatórios." }\end{array}$ & (não definida) \\
\hline
\end{tabular}


Fase 4 - Síntese dos 31 artigos da Lei $n^{\circ}$ 12.608/12 e a identificação de grupos agentes nas CCEs.

Inicialmente, foram identificados quatro grupos de agentes principais que são afetados diretamente pelas determinações da lei: União, Estado, Município e sociedade $^{30}$. Importante ressalvar que em cada ente da Federação há subdivisões envolvendo outros integrantes que participam das contingências comportamentais entrelaçadas. Por exemplo, a estrutura da Defesa Civil mantém seus agentes até o nível municipal; e nos municípios são coordenados por estruturas estaduais em todo o Brasil, com regulamentações próprias de funcionamento estabelecidas por Decretos. No topo do sistema, existe a Estrutura Nacional de Defesa Civil regulamentado pela União, que coordena e estabelece a nível macro as políticas na gestão de riscos de desastres a serem adotadas em território brasileiro.

Quando detectado em uma passagem da lei a interação entre União e Estado, considerou-se existente a interação entre dois agentes nas CCEs estabelecidas no artigo. A Tabela 13 descreve uma síntese dos componentes da Lei categorizados em capítulos, seções e artigos. Dentro de cada artigo, foi avaliado a presença ou inexistência de interação envolvendo algum dos quatro agentes citados anteriormente. Essa descrição buscou responder a pergunta para cada artigo da Lei: "Existem contingências comportamentais entrelaçadas no presente artigo? Se positivo, que grupos de agentes estão envolvidos nesse entrelaçamento comportamental?". A seguir, na Tabela 13, a presença do símbolo • confirma a existência de CCEs entre os respectivos grupos de agentes.

\footnotetext{
${ }^{30}$ O Distrito Federal possui as mesmas competências atribuídas aos Estados e Municípios, conforme determinação do Art. 19.
} 


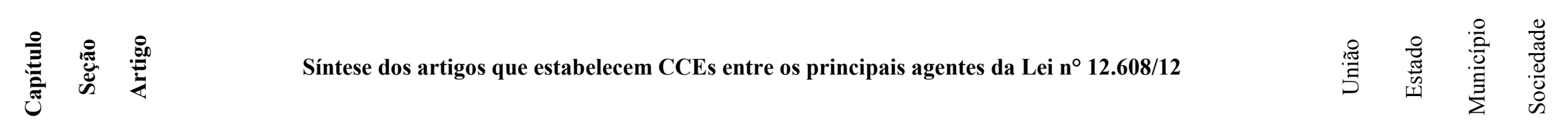

\begin{tabular}{|c|c|c|c|c|c|c|c|}
\hline \multirow[t]{2}{*}{ I } & \multirow[t]{2}{*}{ - } & 1 & $\begin{array}{l}\text { Disposições gerais sobre o estabelecimento da PNPDEC, caracterização da SINPDEC e o CONPDEC, apresentando o } \\
\text { Poder Executivo Federal como estabelecedor das definições técnicas de aplicação da lei. }\end{array}$ & & & & \\
\hline & & 2 & Sinaliza a possibilidade de colaboração de entidades públicas, privadas e sociedade na adoção das medidas instituídas. & - & - & - & - \\
\hline \multirow{7}{*}{ II } & I & 3 & $\begin{array}{l}\text { Descreve a abrangência da PNPDEC em ações de prevenção, mitigação, preparação, resposta e recuperação. Aponta a } \\
\text { necessidade desta política de integrar-se com outras políticas existentes tendo em vista o desenvolvimento sustentável. }\end{array}$ & & $\bullet$ & & - \\
\hline & \multirow{6}{*}{ II } & 4 & Estabelece seis diretrizes da PNPDEC. & - & $\bullet$ & $\bullet$ & $\bullet$ \\
\hline & & 5 & Estabelece quinze objetivos da PNPDEC. & - & $\bullet$ & $\bullet$ & $\bullet$ \\
\hline & & 6 & Responsabilidades da União, descritas em treze parágrafos. & • & $\bullet$ & $\bullet$ & \\
\hline & & 7 & Responsabilidades dos Estados, descritas em oito parágrafos. & - & $\bullet$ & $\bullet$ & \\
\hline & & 8 & Responsabilidades dos Municípios, descritas em dezesseis parágrafos. & & $\bullet$ & $\bullet$ & $\bullet$ \\
\hline & & 9 & Responsabilidades conjuntas da União, Estados e Municípios. & & $\bullet$ & $\bullet$ & $\bullet$ \\
\hline \multirow{3}{*}{ III } & \multirow{2}{*}{ I } & 10 & Disposições gerais sobre o Sistema Nacional de Proteção e Defesa Civil - SINPDEC, sua constituição e finalidade. & - & $\bullet$ & $\bullet$ & \\
\hline & & 11 & Descreve os órgãos que compõem a gestão do SINPDEC. & - & - & - & $\bullet$ \\
\hline & II & 12 & Estabelece cinco finalidades do Conselho Nacional de Proteção e Defesa Civil - CONPDEC. & • & & & \\
\hline \multirow{6}{*}{ IV } & \multirow{6}{*}{ - } & 13 & Autoriza a criação de sistemas de informações e monitoramento de desastres. & - & & & \\
\hline & & 14 & Determina a priorização da realocação das comunidades atingidas por desastres, através dos programas habitacionais. & • & - & • & \\
\hline & & 15 & Descreve a possibilidade de concessão crédito financeiro pela União com a finalidade de auxiliar Municípios atingidos. & • & & & $\bullet$ \\
\hline & & 16 & Autoriza a União a ceder incentivos ao Município quando adotado medidas sobre terras urbanizadas para habitação social. & • & & - & \\
\hline & & 17 & Autoriza a transferência/uso de bens apreendidos em operações de repressão ao crime para órgãos da defesa civil. & & • & • & \\
\hline & & 18 & Descrição dos agentes de proteção e defesa civil. & & - & & - \\
\hline
\end{tabular}


Grupos de agentes

envolvidos nas CCEs

19 Determina que o Distrito Federal possui as mesmas competências atribuídas aos Estados e Municípios.

20 Alteração na Lei $n^{0} 12.340 / 10$ referente a transferências de recursos e sobre o Fundo Especial para Calamidades Públicas.

21 Alteração na Lei n ${ }^{0} 12.340 / 10$ referente a obrigatoriedade nas transferências de recursos

Alteração na Lei $n^{0}$ 12.340/10 referente ao cadastramento nacional de Municípios com áreas suscetíveis a desastres.

22 Aborda-se também diversos procedimentos operacionais e de gestão a serem cumpridos pelos Municípios cadastrados, inclusive a respeito do Plano de Contingência de Proteção e Defesa Civil

23 Aborda aspectos sobre a concessão de licenças e alvarás para construção em áreas de risco.

24 Alteração na Lei $n^{\circ}$ 10.257/01 referente a políticas urbanas no uso e ordenamento do solo, devendo evitar a exposição da

população a riscos de desastres de forma geral (e não somente a desastres naturais).

25 Alteração na Lei $n^{\circ}$ 10.257/01 referente ao cadastro nacional de Municípios, abrangendo outras modalidades de áreas de risco.

26 Alteração na Lei $\mathrm{n}^{0}$ 10.257/01 referente aos critérios a serem atendidos no plano diretor que é cadastrado respectivamente por cada Município no cadastro nacional de áreas suscetíveis a ocorrência de desastres.

27 Alteração na Lei $n^{0}$ 6.766/79 referente aos procedimentos de aprovação de projetos de loteamento e desmembramento.

28 Alteração na Lei $n^{\circ}$ 8.239/91 referente ao treinamento dos serviços alternativos militares para atuação em áreas de desastre.

29 Alteração na Lei n ${ }^{\circ}$ 9.394/96 referente as diretrizes e bases da educação nacional, intervindo no ensino fundamental e médio.

30 Alteração na Lei n ${ }^{\circ}$ 12.340/10 referente as políticas de doação de estoques públicos de alimento.

31 Refere-se a aplicabilidade imediata da Lei assim que efetivada sua publicação. 
A partir das interações apresentadas na Tabela 13, outra pergunta surge para ampliar a descrição das CCEs existentes na lei: "Qual a frequência e a combinação das interações estabelecidas entre os quatro principais grupos de agentes presentes na Lei $n^{o} 12.608 / 12$ ?". O mapeamento da frequência e a combinação de grupos de agentes é apresentado na Figura 8.

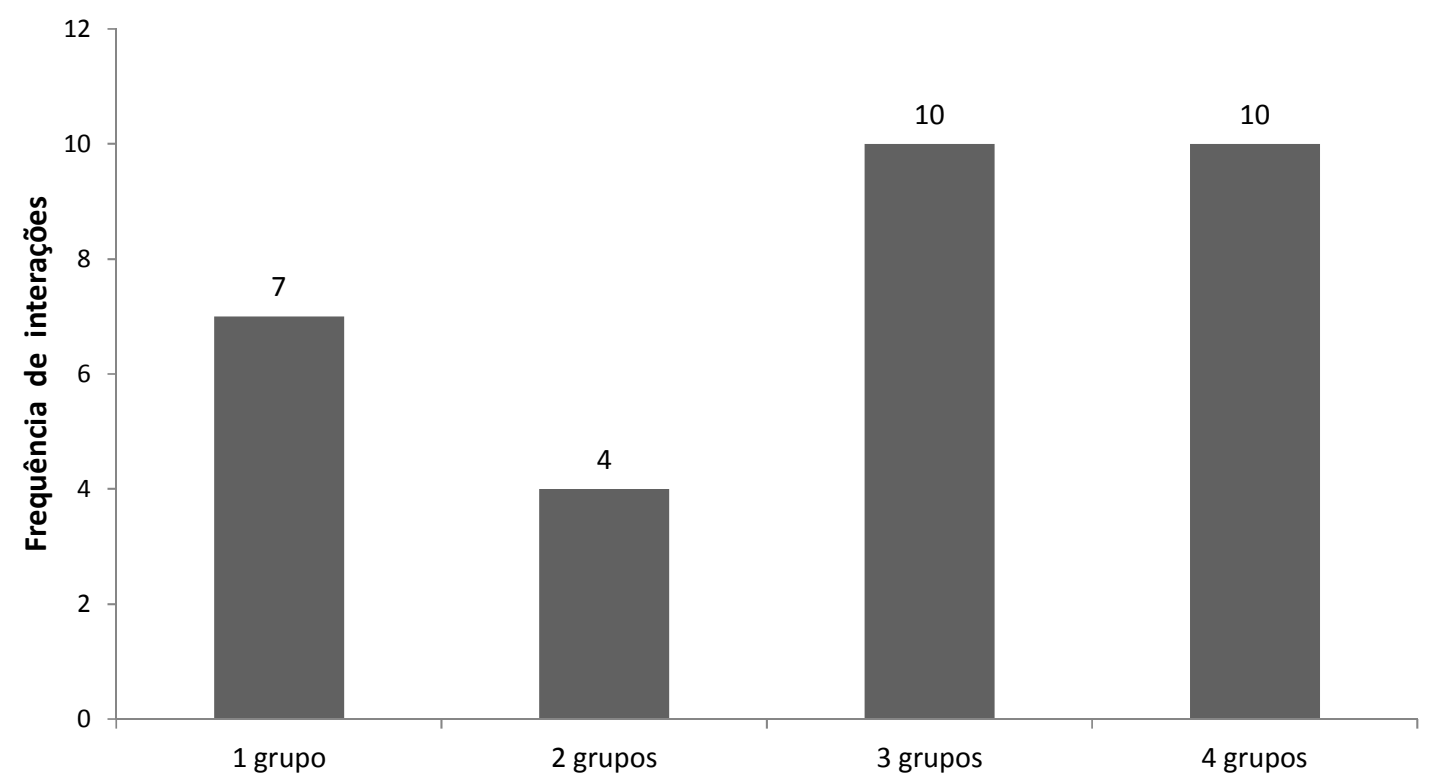

Quantidade de grupos de agentes envolvidos nas CCEs

Figura 8. Frequência de interações entre os principais grupos de agentes na Lei $n^{\circ}$ 12.608/12.

As combinações dessas interações analisadas foram categorizadas como a) interação de 1 grupo de agente; neste caso a interação se limita a entidades do mesmo nível - União, Estado, Município e sociedade; b) interação entre 2 grupos de agentes; c) interação entre 3 grupos de agentes; d) interação entre 4 grupos de agentes. Há predominância de contingências comportamentais entrelaçadas (CCEs) envolvendo a interação de 3 e 4 grupos de agentes, seguido por 1 e 2 grupos de agentes, respectivamente. A União está presente em 29\% dessas interações, o Estado é 
mencionado em 24\%, o Município em $32 \%$ e a Sociedade em $15 \%$ das interações estabelecidas na Lei $\mathrm{n}^{\circ} 12.608$.

\section{Fase 5 - Análise descritiva sobre a composição textual da lei, com base na frequência de repetição de termos-chave.}

Uma outra dimensão de análise descritiva foi proposta a partir da pergunta: “Qual a frequência de repetição de termos-chave específicos na Lei $n^{\circ}$ 12.608/12?”. Após revisão dos principais textos e documentos legais apresentados na seção Fontes desse estudo, foram selecionados 28 termos-chaves, organizados em quatro categorias: Sistemas, Ações, Agentes e Destaques. A escolha dos termos para a análise descritiva textual seguiu quatro critérios: 1) a escolha de termos que descrevessem os principais agentes envolvidos nas CCES presentes na lei; 2) termos que descrevessem os principais PAs no Art. $1^{\mathrm{o}}$; 3) palavras que indicassem ações recorrentes dos agentes envolvidos na lei, conforme diretrizes e objetivos estabelecidos respectivamente nos artigos $4^{\circ}$ e $5^{\circ}$; 4) Termos relevantes e comuns no âmbito da defesa civil, também presentes nos tratados internacionais de Hyogo (2005) e Sendai (2015) estabelecidos pela ONU.

A Tabela 14 mostra que na categoria Ações, os termos mais presentes na lei são respectivamente monitorar e promover. Na categoria Agentes, o Município é citado na lei $50 \%$ a mais do que Estado(s) ou União. A Sociedade, um componente importante nas metacontingências existentes no cenário de gestão de riscos de desastres é mencionada 4 vezes em toda a Lei $\mathrm{n}^{\circ}$ 12.608/12. Diante desta metodologia de categorização de termos, torna-se importante esclarecer que a frequência da repetição de um termo-chave na lei não descreve necessariamente a dimensão ou importância de tal elemento nas contingências entrelaçadas. A metodologia proposta tem sua relevância ao agregar uma outra dimensão descritiva da análise da Lei ${ }^{\circ}$ 12.608/12, complementar as 
fases anteriores. Conforme descrito anteriormente sobre as interações dos quatro grupos principais nas CCES, a sociedade está presente em 15\% das interações previstas na lei, apesar de ser mencionada em apenas quatro pontos da Lei $\mathrm{n}^{\circ} 12.608 / 12$. Na categoria Destaques, o termos desastre(s) é citado na lei em 57 passagens do texto, seguido do termo risco(s), mencionado 36 vezes. Os termos menos citados são consciência nacional com 2 menções, e cidade(s) resiliente(s) com 1 menção em toda a lei.

Tabela 14

Frequência de repetição de termos-chave da Lei $n^{\circ}$ 12.608/12.

\begin{tabular}{|c|c|c|}
\hline Categorias & Termos-chave analisados & $\begin{array}{c}\text { Repetições na Lei } \\
n^{\circ} \mathbf{1 2 . 6 0 8 / 1 2} \\
\end{array}$ \\
\hline \multirow{4}{*}{ Sistemas } & Defesa Civil & 41 \\
\hline & SINPDEC & 21 \\
\hline & PNPDEC & 16 \\
\hline & CONPDEC & 7 \\
\hline \multirow{13}{*}{ Ações } & Monitorar & 12 \\
\hline & Promover & 11 \\
\hline & Instituir & 9 \\
\hline & Recuperar & 9 \\
\hline & Prestar & 8 \\
\hline & Reduzir & 7 \\
\hline & Estimular & 6 \\
\hline & Coordenar & 6 \\
\hline & Planejar & 5 \\
\hline & Autorizar & 5 \\
\hline & Ordenar & 2 \\
\hline & Incorporar & 2 \\
\hline & Priorizar & 1 \\
\hline \multirow{4}{*}{ Agentes } & Municipio(s) & 40 \\
\hline & União & 20 \\
\hline & $\operatorname{Estado}(s)$ & 20 \\
\hline & Sociedade & 4 \\
\hline \multirow{7}{*}{ Destaques } & Desastre(s) & 57 \\
\hline & $\operatorname{Risco}(s)$ & 36 \\
\hline & Lei & 28 \\
\hline & Proteção & 24 \\
\hline & É dever & 15 \\
\hline & Consciência nacional & 2 \\
\hline & Cidade(s) Resiliente(s) & 1 \\
\hline
\end{tabular}


Fase 6 - Descrição do cenário governamental brasileiro de gestão de riscos de desastres, identificando PAs, CCs, e o ambiente selecionador a partir da Lei $\mathbf{n}^{\circ}$ 12.608/12.

Ao observar a Lei $\mathrm{n}^{\circ}$ 12.608/12 como um conjunto de regras que busca estabelecer controle e mudança sobre comportamentos sociais e governamentais, demonstra-se a contribuição do instrumento ao instituir uma extensa rede de interações entre entidades governamentais, representadas pela União, Estados e Municípios, interagindo entre si, com a sociedade e suas representações (civis, voluntários, ONGs, comunidades acadêmicas), juntamente com as entidades privadas que possam colaborar com o sistema de gestão de riscos de desastres. Cada nível do sistema governamental (União, Estado e Município) inclui suas respectivas redes de interação, com subníveis de CCEs, PAs e CCs que em conjunto, criam uma extensa rede de metacontingências entre ministérios, entidades, departamentos, conselhos, centros, coordenações e núcleos.

A interação entre esses agentes governamentais, conforme explícito no Art. $1^{0}$, resulta em três PAs previstos na Lei: 1) criação da Política Nacional de Proteção e Defesa Civil - PNPDEC; 2) estabelecimento do Sistema Nacional de Proteção e Defesa Civil - SINPDEC; 3) criação do Conselho Nacional de Proteção e Defesa Civil CONPDEC.

Outros produtos foram identificados, três aparecem descritos no Art. $2^{\mathrm{o}}$ que estabelece o "dever da União, dos Estados, do Distrito Federal e dos Municípios adotar as medidas necessárias à redução dos riscos de desastre". No Art. 9 ${ }^{\circ}$, inciso I: “desenvolver cultura nacional de prevenção de desastres, destinada ao desenvolvimento da consciência nacional acerca dos riscos de desastre no País"; estes PAs também estão relacionados com outras metacontingências que antecederam a composição da Lei $\mathrm{n}^{\circ}$ 12.608/12: A Constituição Federal de 1988, através do Art. 21º, Inciso XVIII, que 
atribui à responsabilidade da União em "planejar e promover a defesa permanente contra as calamidades públicas, especialmente as secas e as inundações". No cenário atual, uma importante $\mathrm{CC}$ no ambiente selecionador citado refere-se ao reconhecimento internacional condicionado ao bom desempenho do país na campanha Cidades Resilientes, promovida oficialmente pelo Brasil em 2011, que tinha como objetivo central fomentar mundialmente o aumento de países, estados, cidades e municípios com maior planejamento e gestão eficiente quanto aos riscos de desastres. Esta campanha foi desenvolvida pela ONU através do tratado internacional de Hyogo (2005-2015), e sua continuidade foi mantida no recente Marco de Sendai (2015-2030).

O ambiente selecionador nas metacontingências presentes na lei pode ser composto por especialistas da agências governamentais, que também exercem outras funções no entrelaçamento, que resultam na produção dos PAs existentes. Nesse sistema, a ONU, tem função de agente fiscalizador sobre a eficiência das ações governamentais dos países na gestão de riscos de desastres. Outros agentes como a sociedade, a quem se destina os PAs produzidos pelas CCEs estabelecidas na Lei $\mathrm{n}^{\circ}$ 12.608, também atuam como fiscalizadores das ações governamentais. É previsto na lei, a responsabilidade dos Municípios em incentivar atuação de agentes sociais fiscalizando as ações do SINPDEC, responsável pela implementação operacional da PNPDEC, conforme observa-se no Art. $8^{\circ}$, Inciso XV: “Compete aos Municípios (...) estimular a participação de entidades privadas, associações de voluntários, clubes de serviços, organizações não governamentais e associações de classe e comunitárias nas ações do

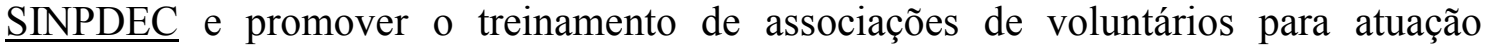
conjunta com as comunidades apoiadas". A síntese dessa rede de agentes é apresentada na Figura 9, que descreve as metacontingências presentes no cenário governamental 
brasileiro de gestão de riscos de desastres, seus componentes e inserção da Lei $\mathrm{n}^{\circ}$ $12.608 / 12$ nesse contexto.

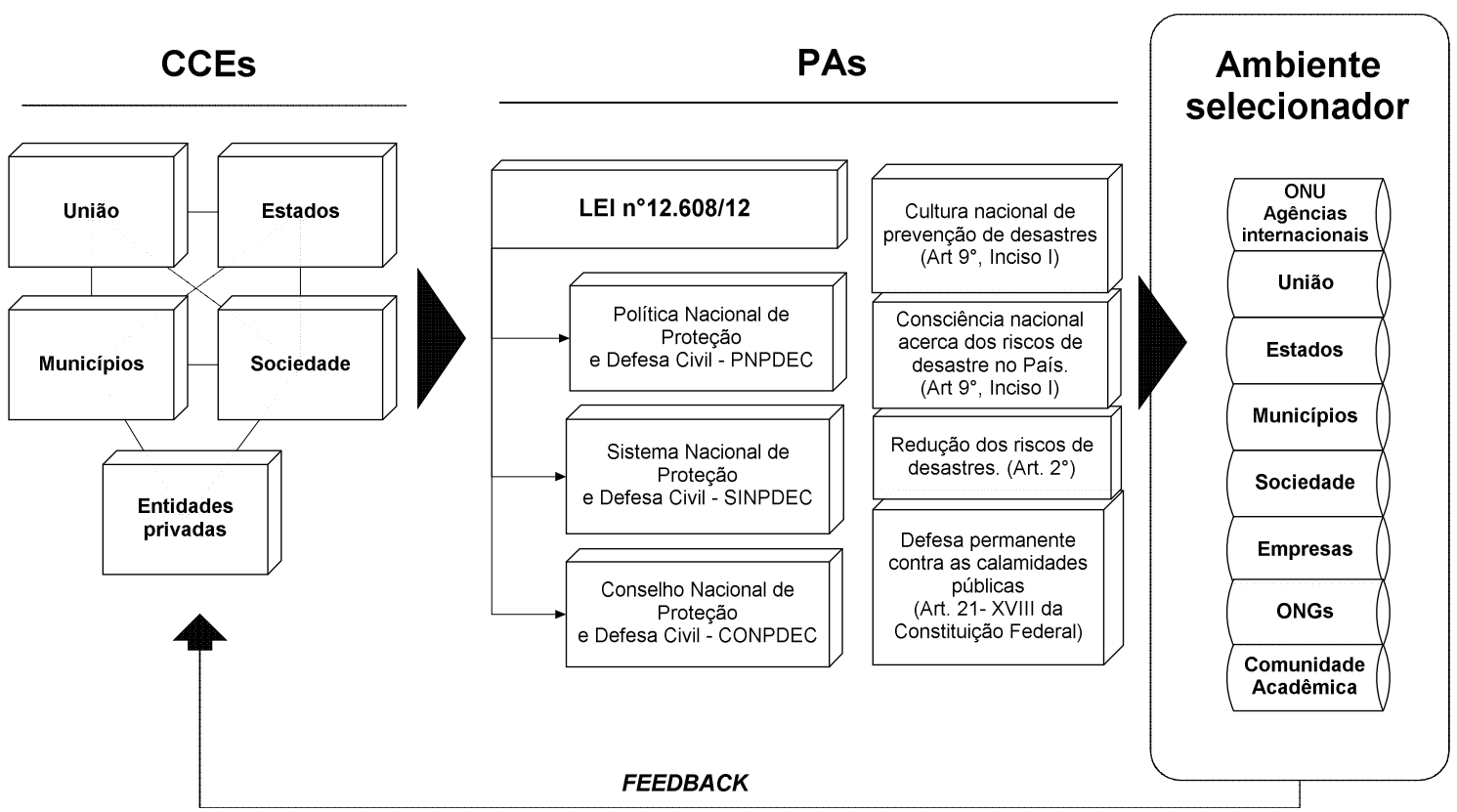

Figura 9. Metacontingências no cenário governamental brasileiro de gestão de riscos de desastres, com a inclusão de possíveis ambientes selecionadores.

Foram identificadas algumas iniciativas da União, de repercussão nacional, que estimulam a seleção e reestruturação das CCEs existentes. A realização de grandes eventos, ciclos chamados de Conferências Nacionais, promovem a construção de macrocomportamentos através da discussão, debates, troca de conhecimento, e interação ativa dos agentes que compõem o ambiente selecionador de práticas culturais. Estas conferências são compostas de ciclos de debates em nível municipal e encerram com um grande encontro nacional dos agentes governamentais e não governamentais envolvidos na gestão dos riscos de desastres no Brasil. Duas conferências nacionais foram realizadas até o presente momento, a $1^{\text {a }}$ Conferência Nacional de Defesa Civil e Assistência Humanitária - CNDC, em março de 2010, que simbolizou uma mobilização regional e intermunicipal de ciclos de debates das políticas de proteção e defesa civil em 
1.179 municípios iniciada em 2009, totalizando mais de 35 mil participantes, com 21\% do total de municípios brasileiros. A partir desses entrelaçamentos multiníveis da sociedade e agentes governamentais promovidos pela $1^{\text {a }} \mathrm{CNDC}$, foram gerados produtos em forma de 104 diretrizes que propuseram mudanças integradas no cenário brasileiro governamental de gestão de riscos de desastres ${ }^{31}$.

Com o objetivo de dar continuidade ao diálogo entre diferentes níveis da sociedade e do governo sobre as mudanças significativas no sistema de defesa civil entre 2010 e 2013, a $2^{\text {a }}$ Conferência Nacional de Proteção e Defesa Civil - CNPDC foi realizada em novembro de 2014, com aproximadamente 1.600 representantes de diversos segmentos da sociedade, do governo e de diferentes áreas de atuação no sistema de defesa civil de todos os estados brasileiros. A nova política nacional de defesa civil estabelecida com a Lei $\mathrm{n}^{\circ} 12.608 / 12$ norteou os temas debatidos durante a conferência. O encontro resultou em 10 Princípios e 30 Diretrizes estabelecendo mudanças sistêmicas que tinham como objetivo o fortalecimento do Sistema Nacional de Proteção e Defesa Civil ${ }^{32}$.

\footnotetext{
${ }^{31}$ Ministério da Integração Nacional. Termo de Referência publicado em 09/09/2013, disponível em: www.pnud.org.br/recrutamento/20130909_1119.pdf

${ }^{32}$ Ministério da Integração Nacional. Relatório Oficial da 2a CNPDC, publicado em jan/2015, disponível em: http://www.mi.gov.br/documents/10157/3935871/Resultado_+2\%C2\%AA+CNPDC.pdf
} 


\section{Discussão}

O presente estudo buscou analisar funcionalmente a Lei Federal $n^{\circ} 12.608 / 12$, a partir da abordagem teórica e metodológica da Análise do Comportamento em um contexto aplicado, com a sistematização de contingências e metacontingências presentes na legislação.

Ao analisar as principais metacontingências presentes na referida lei, responsáveis pelo desdobramento dos demais artigos, identificou-se a ausência de um órgão ou sistema regulador que pudesse selecionar as contingências comportamentais entrelaçadas (CCEs), ou seja, os macrocomportamentos ou as práticas culturais adotadas recorrentes, e seus respectivos resultados sobre a sociedade brasileira (os produtos agregados, PAs). No Art. 12, a descrição da finalidade do CONPDEC com o verbo “auxiliar" na formulação, implementação e execução do Plano Nacional de Proteção e Defesa Civil poderia ser mais claramente introduzido como um órgão deliberativo. $\mathrm{O}$ CONPDEC é citado sete vezes no texto da Lei n 12.608/12 (ver Tabela 14).

Foram identificadas metacontingências incompletas no Art. $9^{\circ}-$ Inciso I: “desenvolver cultura nacional de prevenção de desastres, destinada ao desenvolvimento da consciência nacional acerca dos riscos de desastre no País” e no Art. 2o. “(...) É dever da União, dos Estados, do Distrito Federal e dos Municípios adotar as medidas necessárias à redução dos riscos de desastre”. A análise também apontou que essas metacontingências centrais, que direcionam as ações previstas em toda a Lei $\mathrm{n}^{\circ}$ 12.608/12, tiveram origem em outra metacontingência estabelecida na Constituição Federal, através do Art. $21^{\circ}$, Inciso XVIII, que já previa a necessidade de "planejar e promover a defesa permanente contra as calamidades públicas, especialmente as secas e as inundações". 
A análise estrutural da Lei $n^{\circ} 12.608 / 12$, mostrou que $23 \%$ dos artigos são direcionados para a descrição do principal produto gerado: A Política Nacional de Proteção e Defesa Civil - PNPDEC. Conforme descrito nas Fases 1 e $2^{33}$, o PNPDEC gera outras redes de entrelaçamentos, descritas a partir de 21 ações distribuídas entre diretrizes e objetivos da PNPDEC (Art. $4^{\circ}$ e Art. $5^{\circ}$ ). O Sistema Nacional de Proteção e Defesa Civil - SINPDEC e o Conselho Nacional de Proteção e Defesa Civil CONPDEC são responsáveis, respectivamente, pela operacionalização e coordenação estratégica na implementação efetiva do produto principal (PNPDEC). A recorrência do entrelaçamento dessas contingências comportamentais previstas por Glenn et al. (2016) é um componente importante na manutenção desses produtos e, neste caso, a interação constante do CONPDEC e o SINPDEC deveriam gerar o monitoramento permanente sobre a eficiência quanto ao cumprimento das metas da defesa civil nacional na gestão de riscos de desastres.

Ao analisar a interação da Lei $\mathrm{n}^{\circ}$ 12.608/12 com outras leis brasileiras, identificou-se na Fase 3 que 47\% das metacontingências descritas nos artigos da lei estabelecem entrelaçamentos específicos com outras cinco leis: Lei $\mathrm{n}^{\circ} 12.340 / 10$, Lei $\mathrm{n}^{\mathrm{o}}$ 10.257/01, Lei $n^{0}$ 6.766/79, Lei $n^{0} 8.239 / 91$ e Lei $n^{0}$ 9.394/96. Os resultados obtidos apresentam que a maior quantidade de intervenções identificadas na Lei $n^{\circ}$ 12.608/12 promoviam mudanças na Lei $n^{0} 12.340 / 10$, provavelmente pela importância desta lei que regulamenta o sistema de transferências de recursos da União para os estados e municípios, para uso em situações de calamidade pública e também de prevenção e estruturação da Defesa Civil nos estados e municípios. Diante das metacontingências analisadas em cada uma das cinco leis que fazem interface com a Lei ${ }^{\circ} 12.608 / 12$, com exceção da Lei $\mathrm{n}^{\circ}$ 8.239/91, todas as demais apresentam metacontingências

\footnotetext{
${ }^{33}$ Fases 1 e 2 relativas às descrições de contingências e metacontingências previstas na Lei no ${ }^{\circ}$ 12.608/12.
} 
incompletas, com ausência de consequências diretas que reforcem ou punam a abstenção da união, estados e municípios em relação aos comportamentos esperados de cada agente e aos PAs previstos na Lei ${ }^{\circ} 12.608 / 12$.

A partir da síntese dos artigos da lei e identificação dos agentes nas CCEs, na Fase 4, observa-se nos 31 artigos a interação entre quatro principais agentes (níveis) do sistema de Defesa Civil: União, Estados, Municípios e Sociedade. A análise também demonstra que a maior parte dessas interações é realizada na mesma proporção entre três ou quatro grupos de agentes. Com maior representatividade, os agentes municipais estão presentes em $32 \%$ dos entrelaçamentos previstos na lei, resultado consistente com a Fase $5^{34}$, na qual a frequência da repetição do termo "município" é citado o dobro de vezes no texto da Lei $\mathrm{n}^{\circ}$ 12.608/12, quando comparado aos termos "União" ou "Estados". Estes resultados demonstram coerência se partirmos do pressuposto que os macrocomportamentos protetivos, de prevenção e gerenciamento de riscos de desastres devem funcionar efetivamente no nível municipal, onde esses fenômenos se concretizam. Portanto, de forma consistente os municípios estão envolvidos na maior parte das responsabilidades e ações previstas em lei.

A Lei $\mathrm{n}^{\circ} 12.608 / 12$ foi avaliada também como um compoenente de uma metacontingência maior, descrevendo a extensão da contribuição das contingências presentes na lei sobre a atuação do sistema de Defesa Civil em situações de prevenção e gerenciamento de desastres. A Fase $6^{35}$ mostra a interação da Lei n ${ }^{\circ} 12.608 / 12$ (Art. $2^{\circ}$, Art. 9º, inciso I) e a Constituição Federal de 1988 (Art. 21, Inciso XVIII). As consequências culturais são responsáveis pela seleção dos produtos agregados (Houmanfar \& Rodrigues, 2006; Todorov, 2012). Neste caso, os principais produtos gerados pela lei: PNPDEC, SINPDEC e CONPDEC, são selecionados (mantidos)

\footnotetext{
${ }^{34}$ Análise de frequência de termos-chave utilizados na Lei ${ }^{\circ}$ 12.608/12 (ver Tabela 14).

${ }^{35}$ Descrição do cenário governamental brasileiro de gestão de riscos de desastres, com PAs, CCs e o ambiente selecionador a partir da Lei $\mathrm{n}^{\circ} 12.608 / 12$.
} 
conforme a aceitação ou rejeição destes pelo ambiente selecionador, composto por agentes nacionais e internacionais que fiscalizam e validam a eficiência das ações governamentais no estabelecimento de políticas de prevenção e gerenciamento de riscos de desastres. 


\section{Conclusão}

A pesquisa documental, com análise funcional da Lei $n^{\circ} 12.608 / 12$ apresenta metacontingências comportamentais incompletas, não descrevendo em seu texto as consequências diretas de reforço ou punição previstas em situações de "não cumprimento', na maior parte das ações dispostas para União, Estados e Municípios. Quando previsto, tais punições aparecem em alguns pontos isolados do seu texto como na alteração proposta do Art. $5^{\circ}$-A, da Lei $\mathrm{n}^{\circ}$ 12.340/10. A presença de metacontingências incompletas em leis também foi identificada com frequência em outros estudos similares (e.g., Carvalho, 2014; Martins, 2009; Todorov et al., 2004).

A falta de componentes nas metacontingências presentes em uma lei pode gerar dois problemas: 1) A variabilidade de interpretação da lei, com potenciais efeitos adversos na eficiência do instrumento jurídico (Todorov, 2015); e 2) Não especificação dos agentes do ambiente selecionador (as consequências culturais que irão fortalecer as ações implementadas por um grande número de agentes de diferentes grupos representados nas contingências comportamentais entrelaçadas). Isso dificulta a sistematização de monitoramento e aperfeiçoamento das intervenções culturais sobre contextos de riscos de desastres. Em um contexto específico de gestão de riscos de desastres, a possibilidade tanto do erro de interpretação quanto da abstenção dos órgãos responsáveis na implementação de políticas de proteção e prevenção podem resultar em altos índices de perdas materiais e humanas.

No entanto, a Lei $\mathrm{n}^{\circ} 12.608 / 12$ se mostra como uma legislação flexível ao permitir que uma diversidade de agentes como ONGS, empresas privadas, voluntários e representantes de entidades independentes interajam no sistema e participem como agentes fiscalizadores dos produtos gerados pelo entrelaçamento dos agentes governamentais em diversos níveis. Nesse contexto, apesar do Brasil ter uma grande 
quantidade de municípios inscritos na Campanha 'Cidade Resiliente' promovida pela ONU, esse número corresponde aproximadamente a 5\% de todos os municípios do país. Essa realidade demonstra que apesar dos avanços estabelecidos com a formulação e aprovação da Lei $n^{\circ}$ 12.608/12, na estruturação da Defesa Civil para uma eficiente gestão nacional de riscos de desastres, ainda há esforços nacionais nesta importante campanha implementada no Brasil, buscando a inserção de novas cidades. Vale ressaltar que o Brasil ocupa posição de destaque na adoção da campanha de Cidades Resilientes, em um cenário internacional.

Como instrumento jurídico, a Lei $n^{\circ} 12.608 / 12$ é um produto agregado resultado de uma extensa rede de processos culturais nos níveis nacional e internacional. $O$ cenário de gestão de riscos de desastres é descrito por Glenn et al. (2016) como uma extensa pirâmide de CCEs, as quais são recombinadas mediante as informações disponibilizadas nos relatórios anuais publicados pelo Escritório das Nações Unidas para a Redução do Risco de Desastres - UNISDR. Vasconcelos (2015) demonstra que marcos globais como Hyogo (2005-2015) e Sendai (2015-2030) fundamentam suas metas e ações para reduções na mortalidade em situações de desastres, em grande parte, pelos resultados descritos nos relatórios da UNISDR. Organizações locais independentes em cada um dos 188 países integrantes mapeiam essas informações e repassam ao UNISDR. A padronização na origem dessas informações é descrita por Glenn et al. (2016) como um importante ponto de influência sobre a eficiência dos produtos agregados gerados nessa extensa rede de CCEs, previstas na Lei $\mathrm{n}^{\circ}$ 12.608/12 e no sistema de defesa civil brasileiro.

Diante desse cenário, o complexo sistema legislativo que regulamenta as ações da Defesa Civil no Brasil se desdobra em inúmeros decretos, normas e resoluções 
regionais (que variam entre os 26 estados e 5.570 municípios $^{36}$ ). A Lei n ${ }^{\circ}$ 12.608/12 e suas normatizações derivadas fazem parte do sistema legislativo brasileiro composto por mais de 181 mil leis ${ }^{37}$. Essa extensa ramificação das responsabilidades e interações entre os agentes governamentais também aumenta o desafio no estabelecimento de macrocomportamentos protetivos que possam ser transmitidos culturalmente entre os entes federados e a população civil.

De forma geral, a Lei Federal $n^{\circ} 12.608 / 12$ caracteriza-se como um instrumento jurídico que amplia as redes de interação entre a sociedade e agentes públicos em diversos níveis, buscando aumentar a eficiência das ações governamentais no estabelecimento de políticas de prevenção e gerenciamento de riscos de desastres. Uma análise funcional da evolução de práticas culturais contribui para o planejamento cultural em cumprimento do sistema ético skinneriano (ver Dittrich \& Abib, 2004). Para a Análise do Comportamento a sobrevivência da cultura tem valor de destaque. E, o alto impacto de desastres sobre perdas humanas e materiais em um cenário global justifica a existência de intervenções em larga escala, interdisciplinares, com contribuição da Análise do Comportamento. A análise funcional de leis pode potencializar resultados eficientes de tais intervenções.

\footnotetext{
${ }^{36}$ Dados do Instituto Brasileiro de Geografia e Estatística (IBGE). Disponível em http://www.ibge.gov.br.

${ }^{37}$ Artigo "O Brasil das 181 mil leis" - Publicado na Revista Istoé, no 1.953, 2007.
} 


\section{Referências}

Alves, H. P. D. F., \& Torres, H. D. G. (2006). Vulnerabilidade socioambiental na cidade de São Paulo: uma análise de famílias e domicílios em situação de pobreza e risco ambiental. Perspect, 20(1), 44-60.

Amorim, V. C. (2010). Análogos experimentais de metacontingências: efeitos da intermitência da consequência cultural. Dissertação de Mestrado. Pontifícia Universidade Católica de São Paulo, São Paulo.

Azevedo, R. M. F. (2015). Controle discriminativo em metacontingência. Dissertação de mestrado. Universidade de Brasília, Brasília.

Baia, F. H. (2008). Microssociedades no laboratório: o efeito de consequências ambientais externas sobre as contingências comportamentais entrelaçadas e seus produtos agregados. Dissertação de Mestrado. Universidade de Brasília, Brasília.

Baia, F. H., Azevedo, F. F., Segantini, S. M., Macedo, R. P., \& Vasconcelos, L. A. (2014). Effects of different magnitudes of individual consequences and cultural consequences on culturant's selection. Acta Comportamentalia, 23(3), 257-272.

Barros, A. B.; \& Barros, A. M. A. (2009). A difícil aplicabilidade da política de águas no Brasil. InterSciencePlace, 1(7).

Baum, W. M. (2005). Compreender o Behaviorismo: Comportamento, cultura e evolução. 2.ed. Porto Alegre: Artmed Editora S.A.

Baum, W. M; Richerson, P. J.; Efferson, C. M.; \& Paciotti, B. M. (2004). Cultural evolution in laboratory microsocietis including traditions of rule giving and rule following. Evolution and Human Behavior, 25, 305-326.

Bavelas, A., Hastorf, A. H., Gross, A. E., \& Kite, W. R. (1965). Experiments on the alteration of group structure. Journal of Experimental Social Psychology, 1(1), 5570. 
Bodstein, A., De Lima, V. V. A., \& De Barros, A. M. A. (2014). A vulnerabilidade do idoso em situações de desastres: necessidade de uma política de resiliência eficaz. Ambiente \& Sociedade, 17(2), 157-174.

Borba, A., Silva, B. R., Cabral, P. A. A., Souza, L. B., Leite, F. L., \& Tourinho, E. Z. (2014). Effects of exposure to macrocontingencies in isolation and social situations in the production of ethical self-control. Behavior and Social Issues, 23, 5-19.

Borba, A., Tourinho, E. Z., \& Glenn, S. S. (2014). Establishing the macrobehavior of ethical self-control in an arrangement of macrocontingencies in two microcultures. Behavior and Social Issues, 23, 68-86.

Brasil. (2007). Ministério da Integração Nacional. Secretaria Nacional de Defesa Civil. Aspectos jurídicos das atividades de defesa civil. Brasília: Secretaria Nacional da Defesa Civil.

Brasil. (2010). Ministério da Integração Nacional. Defesa Civil no Brasil. $1^{a}$ Conferência Nacional de Defesa Civil e Assistência Humanitária. Brasília: Secretaria Nacional de Defesa Civil.

Brasil. (2011/2012). Ministério da Integração Nacional. Anuário Brasileiro de Desastres Naturais. Centro Nacional de Gerenciamento de Riscos e Desastres CENAD, Brasília.

Brasil. (2014). Ministério da Integração Nacional. Secretaria Nacional de Defesa Civil. Sitio Governamental. Recuperado em: < http://www.integracao.gov.br>.

Brasiliano, A. C. R. (2011). Um Modelo de Análise de Risco para Desastres - RJ. Revista Gestão de Risco, 62, 07-23.

Brocal, A. L. (2010). Análogos experimentais de metacontingências: o efeito da retirada da consequência individual. Dissertação de Mestrado. Pontifícia Universidade Católica de São Paulo, São Paulo. 
Bruck, N. R. V. (2007). A Psicologia das Emergências: Um estudo sobre angústia pública e o dramático cotidiano do trauma. Tese de Doutorado. Pontifícia Universidade Católica do Rio Grande do Sul, Rio Grande do Sul.

Bullerjhann, P. B. (2009). Análogos experimentais de fenômenos sociais: O efeito das consequências culturais. Dissertação de Mestrado. Pontifícia Universidade Católica de São Paulo, São Paulo.

Cabral, C. Z. (2007). Descrição e análise das contingências presentes na proposta de estatuto da pessoa com deficiência. Dissertação de Mestrado. Universidade Estadual Paulista de Bauru, Bauru.

Cabral, M. D. C. (2014). Contingências e metacontingências envolvidas no processo legislativo da Lei $n^{\circ} 12.433$, de 29 de junho de 2011. Dissertação de Mestrado. Universidade de Brasília, Brasília.

Caldas, R. A. (2009). Análogos experimentais de seleção e extinção de metacontingências. Dissertação de Mestrado. Pontifícia Universidade Católica de São Paulo, São Paulo.

Carvalho, I. C. V. D. (2014). Contingências e metacontingências na lei de diretrizes e bases da educação nacional - LDB. Dissertação de Mestrado. Universidade de Brasília, Brasília.

Castro, A. L. C. de. (2004). Manual de Planejamento em Defesa Civil. (Vol. II). Ministério da Integração Nacional. Brasília: Secretaria de Defesa Civil.

Cavalcanti, D. E., Leite, F. L., \& Tourinho, E. Z. (2014). Seleção de Práticas culturais complexas: Avaliação experimental de um análogo do procedimento de aproximação sucessiva. Psicologia e Saber Social, 3, 2-21.

CEPED (2011). Atlas brasileiro de desastres naturais 1991 a 2010: Volume Brasil. Florianópolis: CEPED UFSC. 
Coelho, A. E. L. (2010). A psicologia em situações de emergências e desastres. Jornal CRP 13 - Psicologia e Direitos Humanos. Rio de Janeiro.

Costa, D. C. (2008). Dilema do Prisioneiro: efeitos das consequências individuais e culturais sobre as escolhas de cooperação e competição. Dissertação de Mestrado. Universidade de Brasília, Brasília.

Costa, D. C. (2013). Metacontingências no uso de recursos naturais: o ambiente natural com pescadores e o laboratório com o Jogo Dilema dos Comuns. Tese de Doutorado. Universidade de Brasília, Brasília.

Costa, D., Nogueira, C. P. V., \& Vasconcelos, L. A. (2012). Effects of communication and cultural consequences on choices combinations in INPDG with four participants. Revista Latinoamericana de Psicología, 44, 121-131.

Couto, J. M. (2003). Entre estatais e transnacionais: o pólo industrial de Cubatão. Tese de Doutorado. Instituto de Economia da Unicamp.

De Melo, C. M., \& de Rose, J. C. C. (2012). Sobrevivência das Culturas em Skinner: Um Diálogo com o Materialismo Cultural de Harris. Psicologia, Teoria e Pesquisa, 28(1), 119-128.

De Toledo, T. F. N., Benvenuti, M. F. L., Sampaio, A. A. S., Marques, N. S., Cabral, P. A. A., Araujo, L. A., Machado, L. R., \& Moreira, L. R. (2015). Free culturant: a software for the experimental study of behavior and cultural selection. Psychology and Neuroscience, $8,366-384$

Dias, A. L. F.; Passarelli, A. C.; Vilaca, C. C.; \& Carneiro, I. J. P. (2006). Análise e descrição comportamental da Legislação de Recursos Hídricos. Anais da $58^{a}$ Reunião Anual da SBPC. Florianópolis, Santa Catarina. 
Dittrich, A., \& Abib, J. A. D. (2004). O sistema ético skinneriano e conseqüências para a prática dos analistas do comportamento. Psicologia: reflexão e crítica, 17(3), 427433.

Dos Santos, P. M. (2011). É possivel produzir variabilidade em metacontingências? Dissertação de Mestrado. São Paulo: Pontifícia Universidade Católica de São Paulo. Dourado, F., Arraes, T. C., \& Silva, M. (2012). O Megadesastre da Região Serrana do Rio de Janeiro: as causas do evento, os mecanismos dos movimentos de massa e a distribuição espacial dos investimentos de reconstrução no pós-desastre. Anuário do Instituto de Geociências, 35(2), 43-54.

Dynes, R. R.; \& Drabek, T. E. (1994). The structure of disaster research: its policy and disciplinary implications. International Journal of Mass Emergencies and Disasters. $12(1)$, pp. $5-23$.

EM-DAT — The International Disaster Database; \& CRED — Centre For Research On The Epidemiology Of Disasters. (2014). Disaster Trends. In: Handbook of Bioterrorism and Disaster Medicine, 7-9, Springer: US.

Fava, V. M. D. (2015). Comportamento das familias beneficiárias do Programa Bolsa Família: uma perspectiva analítico-comportamental do cumprimento das condicionalidades de Educação e de Saúde. Tese de Doutorado. Universidade de Brasília, Brasília.

Forero, D. D. R., García, D. A., Silva, L. M., \& López-López, W. (2012). Análisis metacontingencial de la Ley de “Justicia y Paz" (975 de 2005) en Colombia. Revista Latinoamericana de Psicología, 44(1), 149-157.

Fraley, L. E. (1988). Introductory comments: Behaviorology and cultural materialism. The Behavior Analyst, 11(2), 159-160. 
Franceschini, A. C. T., Samelo, M. J., Xavier, R. N., \& Hunziker, M. H. L. (2012). Effects of consequences on patterns of interlocked contingencies: A replication of a metacontingency experiment. Revista Latinoamericana de Psicología, 44, 87-95.

Freitas, R. C. M.; \& De Campos, C. C. (2010). Questões Socioambientais e Gênero: A participação da mulher em situações de desastre. In: Seminário Internacional Fazendo Gênero 9: Diásporas, diversidades, deslocamentos. Universidade Federal de Santa Catarina.

Furtado, J., Oliveira, M. D., Dantas, M. C., Souza, P. P., \& Panceri, R. (2012). Capacitação Básica em Defesa Civil. Centro Universitário de Pesquisa e Estudos sobre Desastres CAD/UFSC, Florianópolis, Santa Catarina.

Gadelha, C. T. (2010). Evolução cultural em análogos experimentais de metacontingências: seleção de diferentes produtos agregados. Dissertação de Mestrado. Pontifícia Universidade Católica de São Paulo, São Paulo.

Glenn, S. S., \& Malott, M. E. (2004). Complexity and selection: implications for organizational change. Behavior and Social Issues, 13, 86-106.

Glenn, S. S. (1986). Metacontingencies in Walden Two. Behavior Analysis and Social Action, 5, 2-8.

Glenn, S. S. (1988). Contingencies and metacontingencies: Toward a synthesis of behavior analysis and cultural materialism. The Behavior Analyst, 11, 161-169.

Glenn, S. S. (1991). Contingencies and Metacontingencies: Relations among Behavioral, Cultural, and Biological Evolution. In: P.A. Lamal (ed.) Behavioral Analysis of Societies and Cultural Practices, 39-73. New York: Hemisphere Publishing Corporation. 
Glenn, S. S. (2003). Operant contingencies and the origin of cultures. In: K. A. Lattal \& P. N. Chase (Orgs.), Behavior theory and philosophy, 223-242. New York: Klewer Academic/Plenum.

Glenn, S. S. (2008). Toward experimental analysis of contingencies of selection in experimental micro-societies. In: VIII Encontro de Análise do Comportamento do Centro-Oeste, Brasília, DF.

Glenn, S. S. (2010). Metacontingencies, selection and OBM: Comments on Emergence and Metacontingency. Behavior and Social Issues, 19, 79-85.

Glenn, S. S., Malott, M., Andery, M., Benvenuti, M., Houmanfar, R., Sandaker, I., Todorov, J., Tourinho, E., \& Vasconcelos, L. (2016). Toward Consistent Terminology in a Behaviorist Approach to Cultural Analysis. Behavior And Social Issues, 25, 11-27.

Gomes Jr., Araújo, C. A.; \& Alves, M. L. (2003). Capacitação em Defesa Civil. Florianópolis: Editora Nova Letra.

Hayes, L. J., \& Houmanfar, R. (2004). Units and measures: A response to Glenn and Malott. Behavior and Social Issues, 13, 107-111.

Houmanfar, R.; \& Rodrigues, N. J. (2006). The metacontingency and the behavioral contingency: Points of contact and departure. Behavior and Social Issues, 15, 13-30.

Hunter, C. S. (2012). Analysing behavioral and cultural selection contingencies. Revista Latinoamericana de Psicologia, 44(1), 43-54.

Kobiyama, M., Checchia, T., Silva, R., Schröder, P., Grando, A., \& Reginatto, G. (2004). Papel da comunidade e da universidade no gerenciamento de desastres naturais. Simpósio Brasileiro de Desastres Naturais, 1, 834-846. 
Kuhn, K., Campbell-Lendrum, D., Haines, A., Cox, J., Corvalán, C., \& Anker, M. (2005). Using climate to predict infectious disease epidemics. Geneva: World Health Organization.

Lamal, P. A. (1991). Behavioral analysis of societies and cultural practices. In: P. A. Lamal (Org.), Behavioral analysis of societies and cultural practices, 3-12. New York: Hemisphere Publishing Corporation.

Leite, F. L. (2009). Efeitos de instruções e história experimental sobre a transmissão de práticas de escolha em microculturas de laboratório. Dissertação de mestrado. Universidade Federal do Pará. Belém.

Lopes, E. B. (2010). Um análogo experimental de uma prática cultural: Efeitos de um produto agregado contingente, mas não contíguo, sobre uma contingência de reforçamento entrelaçada. Dissertação de mestrado. Universidade Federal do Pará. Belém, Pará.

Lucente, R. J.; \& Manacez, G. (1999). Histórico e Evolução da Defesa Civil no Brasil. Governo do Estado do Rio de Janeiro, Secretaria de Estado de Defesa Civil.

Malott, E. M; \& Glenn, S. S. (2006). Targets of intervention in cultural and behavior change. Behavior and Social Issues, 15, 31-56.

Malott, R. W. (2010). I'll save the world from global warming - Tomorrow. The Behavior Analyst, 33, 179-180.

Marengo, J. A., Valverde, M. C., \& Obregon, G. O. (2013). Observed and projected changes in rainfall extremes in the Metropolitan Area of São Paulo. Climate research, 57(1), 61-72.

Martins, A. L. A. (2009). $\quad$ O Sistema Único de Saúde: contingências e metacontingências nas Leis Orgânicas de Saúde. Dissertação de mestrado, Universidade de Brasília, Brasília. 
Martins, T. G. (2014). A legislação de educação especial e a instituição de escolas inclusivas: uma análise a partir do conceito de metacontingência. Tese de Doutorado. Pontifícia Universidade Católica de São Paulo, São Paulo.

Martone, R. C. (2008). Efeito de consequências externas e de mudanças na constituição do grupo sobre a distribuição dos ganhos em uma metacontingência experimental. Tese de Doutorado. Universidade de Brasília, Brasília.

Martone, R. C.; \& Todorov, J. C. (2007). O Desenvolvimento do Conceito de Metacontingência. Revista Brasileira de Análise do Comportamento, Brasília, 3(2), $181-190$.

Massing, C. R.; Lise, F. A.; \& Gaio, J. M. (2009). Psicologia das emergências e dos desastres: Intervenções em Guaraciaba-SC. V Seminário Internacional da Defesa Civil - DEFENCIL, São Paulo.

Matos, M. A. (2001). Comportamento governado por regras. Revista Brasileira de Terapia Comportamental e Cognitiva, 3(2), 51-56.

Naves, A. R. C. X. (2013). Relações entre a mídia e leis nas mudanças da família brasileira: uma análise comportamental da evolução de práticas culturais. Tese de Doutorado. Universidade de Brasília, Brasília.

Nogueira, C. P. V. (2009). Seleção de diferentes culturantes no Dilema do Prisioneiro: efeito da interação entre consequência cultural, escolhas simultâneas ou seqüenciais e a comunicação. Dissertação de Mestrado. Universidade de Brasília, Brasília.

Nogueira, E. E. (2010). De Macrocontingências à Metacontingências no jogo Dilema dos Comuns. Dissertação de Mestrado. Universidade de Brasília, Brasília. 
Oda, L. V. (2009). Investigação das interações verbais em um análogo experimental de metacontingência. Dissertação de Mestrado. Pontifícia Universidade Católica de São Paulo, São Paulo.

O'Keefe, P., Westgate, K., \& Wisner, B. (1976). Taking the naturalness out of natural disasters. Nature, 260, 566-567.

Oliveira, R. M. M. de (2015). Metacontingência: um experimento com variabilidade operante do produto agregado. Dissertação de Mestrado. Universidade de Brasília, Brasília.

Ortu, D., Becker, A. M., Woelz, T. A. R., \& Glenn, S. S. (2012). An iterated four player prisoner's dilemma game with an external selecting agent: A metacontingency experiment. Revista Latinoamerica de Psicologia , 44, 111-120.

Pereira, G. C. C. (2006). Metacontingência e o estatuto da criança e do adolescente: uma análise da correspondência entre a lei e os comportamentos dos aplicadores do direito e executores da lei. Dissertação de Mestrado, Universidade de Brasília, Brasília.

Pereira, J. M. C. (2008). Investigação experimental de metacontingências: separação do produto agregado e da consequência individual. Dissertação de mestrado. Pontifícia Universidade Católica de São Paulo, São Paulo.

Prudêncio, M. G. A. (2006). Leis e Metacontingências: Análise do controle do Estatuto da Criança e do Adolescente sobre práticas Jurídicas em Processos de Infração de Adolescentes no Distrito Federal. Dissertação de Mestrado. Universidade de Brasília, Brasília.

Quarantelli, E. L., \& Dynes, R. R. (1977). Response to social crisis and disaster. Annual review of sociology, 23-49. 
Rodriguez, H.; Quarantelli, E. L.; \& Dynes, R. R. (2007). Handbook of Disaster Research, New York: Springer.

Rogers, C. R., \& Skinner, B. F. (1956). Some issues concerning the control of human behavior. Science, 124, 1057-1066.

Sampaio, A. A. S.; \& Andery, M. A. P. A. (2007). Análise de fenômenos sociais: O que é prática cultural. In: Anais do XVI Encontro Brasileiro de Psicoterapia e Medicina Comportamental, Brasília, 16, 116.

Sampaio, A. A. S. (2008). A quase-experimentação no estudo da cultura: análise da obra Colapso de Jared Diamond. Dissertação de Mestrado, Pontifícia Universidade Católica de São Paulo, São Paulo.

Sandaker, I. (2009). A selectionist perspective on systemic and behavioral change in organizations. Journal of Organizational Behavior Management, 29(3), 276-293.

Silva, N. C. S. (2011). Custo da resposta no jogo Dilema dos Comuns: análogo experimental de macrocontingências. Dissertação de Mestrado. Universidade de Brasília, Brasília.

Skinner, B. F. (1948/1975). Walden II: uma sociedade do futuro. Trad.: R. Moreno, \& N. R. Saraiva. $2^{\mathrm{a}}$ reimpressão. São Paulo: EPU.

Skinner, B. F. (1953/2007). Ciência e comportamento humano. Trad.: J. C. Todorov, \& R. Azzi. São Paulo: Martins Fontes.

Skinner, B. F. (1957/1978). O comportamento verbal. São Paulo: Cultrix.

Skinner, B. F. (1969/1984). Contingências de reforço: uma análise teórica. Trad.: R. Moreno. $2^{\mathrm{a}}$ edição. São Paulo: Abril Cultural.

Skinner, B. F. (1971/1983). O Mito da Liberade. Trad.: E. R. B. Rebelo. $3^{\text {a }}$ edição. São Paulo: Summus. 
Skinner, B. F. (1978). Walden Two revisited. In: B. F. Skinner, Reflections on behaviorism and society, 56-67. Englewoods Cliffs, N.J.: Prentice - Hall.

Skinner, B. F. (1981/2007). Seleção pelas Consequências. Revista Brasileira de Terapia Comportamental e Cognitiva, IX (1), 129-137.

Spink, M. J. P. (2014). Living in areas of risk: tensions between management of environmental disasters and the significance of risk in everyday life. Ciência \& Saúde Coletiva, 19(9), 3743-3754.

Tadaiesky, L. T. (2010). Efeitos de contingências de suporte e de metacontingências sobre a seleção de contingências comportamentais entrelaçadas. Dissertação de mestrado, Universidade Federal do Pará, Belém, Pará.

Thomas, A. S.; \& Kopczak, L. R. (2005). From logistics to supply chain management: The path forward in the humanitarian sector. Fritz Institute. San Francisco.

Todorov, J. C. (1987). A Constituição como metacontingência. Psicologia, Ciência e Profissão, 7(1), 9-13.

Todorov, J. C. (2005). Laws and the complex control of behavior. Behavior and Social Issues, 14(2), 86 .

Todorov, J. C. (2009). Behavioral Analysis of non-experimental data associated with cultural practices. Behavior and Social Issues, 18, 10-14.

Todorov, J. C. (2012). Metacontingências e a análise comportamental de práticas culturais. Clínica \& Cultura, 1(1), 36-45.

Todorov, J. C.; Moreira, M.; Prudêncio, M. R. A. \& Pereira, G. C. C. (2004). O Estatuto da Criança e do Adolescente como metacontingência. In: M. Z. S. Brandão; F. C. S. Conte; F. S. Brandão; Y. K. Ingberman; V. L. M. Silva; S. M. Oliani (orgs). Sobre Comportamento e Cognição: contingências e metacontingências, contextos sócioverbais e o comportamento do terapeuta, 44-51. Santo André: ESETec. 
Todorov, J. C., \& Vasconcelos, I. (2015). Experimental analysis of the behavior of persons in groups: Selection of an aggregate product in a metacontingency. Behavior and Social Issues, 24, 111-125.

Tomasini, R. M.; \& Van Wassenhove, L. N. (2009) From preparedness to partnerships: case study research on humanitarian logistics. International Transactions in Operational Research, 16, 549-559.

Tominaga, L. K.; Santoro, J.; Amaral, R. (Orgs). (2009). Desastres naturais: conhecer para prevenir. São Paulo: Instituto Geológico.

Tourinho, E. Z. (2013). Cultural consequences and interlocking behavioral contingencies: Selection at the cultural level. Behavior and Philosophy, 41, 60-69.

Twyman, J. S. (2010). TerraKids. The Behavior Analyst, 33, 193-196.

UNISDR. (2009). Terminology on disaster risk reduction. Genebra, ONU.

UNISDR. (2012). Como Construir Cidades Mais Resilientes - Um Guia Para Gestores Públicos Locais (2005-2015). Genebra, ONU.

Valêncio, N. (2010). Desastres, Ordem Social e Planejamento em Defesa Civil: o contexto brasileiro. Saúde e Sociedade, São Paulo. 19(4), 748-762.

Vasconcelos, I. G. (2014). Procedimento experimental de modelagem de respostas para seleção do produto agregado em metacontingências. Dissertação de Mestrado. Universidade de Brasília, Brasília.

Vasconcelos, L. A. (1999). Radiação Ionizante: Efeitos sobre a Aquisição e o Desempenho do Comportamento Operante. Tese de Doutorado. Universidade de Brasília, Brasília.

Vasconcelos, L. A.; Gimenes, L. S. (1991). Indicadores de sáude e ansiedade em indivíduos expostos à radiação ionizante por Césio-137. In: XXI Reunião Anual de 
Psicologia, Caderno de Comunicações Científicas. Ribeirão Preto: SBPRP, 1991. 1, 84.

Vasconcelos, L. A.; Gimenes, L. S. (1993). Aspectos psicológicos analisados em diferentes contextos de acidentes radioativos. In: I Simpósio sobre os aspectos psicossociais do acidente com Césio-137, Goiânia.

Vasconcelos, L. A.; Gimenes, L. S.; \& Todorov, J. C. (1993). Um estudo experimental dos efeitos sobre tomada de decisão em situação de risco. In: II Simpósio Internacional sobre o Acidente Radioativo com Césio-137, Goiânia.

Vasconcelos, L. A. (2015). The culture in disaster risk reduction ecosystems: Evolvement of operants of individuals and the IBCs of organizational entities. In: Think Tank on Social Contingencies: Individual, Culture and Society - Regional Meeting of the Brazilian Society of Psychology. Universidade de São Paulo, São Paulo.

Verona, H. C. (2011). Psicologia de emergências e desastres na América Latina: Promoção de direitos e construção de estratégias de atuação. Psicologia: Ciência e Profissão, 31, 5-7.

Vichi, C. (2005). Igualdade ou Desigualdade: Manipulando um análogo experimental de prática cultural em laboratório. In: J. C. Todorov, R. C. Martone, M. B. Moreira (Orgs.), Metacontingências: comportamento, cultura e sociedade, 81-100. Santo André: ESETec.

Vichi, C. (2012). Efeitos da apresentação intermitente de consequências culturais sobre contingências comportamentais entrelaçadas e seus produtos agregados. Tese de Doutorado. Universidade Federal do Pará, Belém. 
Vichi, C., Andery, M. A. P. A., \& Glenn, S. S. (2009). A metacontingency experiment: the effects of contingent consequences on patterns of interlocking contingencies of reinforcement. Behavior and Social Issues, 18, 41-57.

Vichi, C., \& Tourinho, E. Z. (2012). Consequências culturais x consequências comportamentais na literatura experimental de pequenos grupos. Acta Comportamentalia, 20, 201-215.

Vieira, M. C. (2010). Condições antecedentes participam de metacontingências?. Dissertação de Mestrado. Pontifícia Universidade Católica de São Paulo, São Paulo.

Wiggins, J. (1969). Status differentiation, external consequences and alternative reward distributions. In: R. L. Burgess, \& D. Bushell (Eds.), Behavioral sociology: The experimental analysis of social process, 109-126. New York: Columbia University Press. 


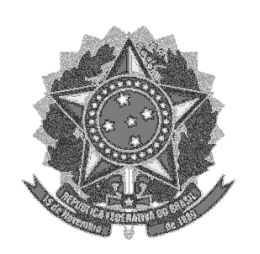

\section{Presidência da República Casa Civil Subchefia para Assuntos Jurídicos}

\section{LEI № 12.608, DE 10 DE ABRIL DE 2012.}

\section{Vigência}

Conversão da Medida Provisória $n^{\circ} 547$, de $\underline{\text { 2011) }}$
Institui a Política Nacional de Proteção e Defesa Civil - PNPDEC; dispõe sobre o Sistema Nacional de Proteção e Defesa Civil - SINPDEC e o Conselho Nacional de Proteção e Defesa Civil - CONPDEC; autoriza a criação de sistema de informações e monitoramento de desastres; altera as Leis $\mathrm{n}^{\text {os }} 12.340$, de $1^{\circ}$ de dezembro de 2010,10.257, de 10 de julho de 2001, 6.766, de 19 de dezembro de 1979, 8.239, de 4 de outubro de 1991, e 9.394, de 20 de dezembro de 1996; e dá outras providências.

O VICE-PRESIDENTE DA REPÚBLICA, no exercício do cargo de PRESIDENTE DA REPÚBLICA Faço saber que o Congresso Nacional decreta e eu sanciono a seguinte Lei:

\section{CAPÍTULO i}

\section{DISPOSIÇÕES GERAIS}

Art. $1^{\circ}$ Esta Lei institui a Política Nacional de Proteção e Defesa Civil - PNPDEC, dispõe sobre o Sistema Nacional de Proteção e Defesa Civil - SINPDEC e o Conselho Nacional de Proteção e Defesa Civil - CONPDEC, autoriza a criação de sistema de informações e monitoramento de desastres e dá outras providências.

Parágrafo único. As definições técnicas para aplicação desta Lei serão estabelecidas em ato do Poder Executivo federal.

Art. $2^{2}$ É dever da União, dos Estados, do Distrito Federal e dos Municípios adotar as medidas necessárias à redução dos riscos de desastre. (Regulamento)

$\S 1^{\circ}$ As medidas previstas no caput poderão ser adotadas com a colaboração de entidades públicas ou privadas e da sociedade em geral.

$\S 2^{\circ}$ A incerteza quanto ao risco de desastre não constituirá óbice para a adoção das medidas preventivas e mitigadoras da situação de risco. 


\title{
CAPÍTULO li
}

\section{DA POLÍTICA NACIONAL DE PROTEÇÃO E DEFESA CIVIL - PNPDEC}

\author{
Seção I
}

Diretrizes e Objetivos

Art. 3ํ A PNPDEC abrange as ações de prevenção, mitigação, preparação, resposta e recuperação voltadas à proteção e defesa civil.

Parágrafo único. A PNPDEC deve integrar-se às políticas de ordenamento territorial, desenvolvimento urbano, saúde, meio ambiente, mudanças climáticas, gestão de recursos hídricos, geologia, infraestrutura, educação, ciência e tecnologia e às demais políticas setoriais, tendo em vista a promoção do desenvolvimento sustentável.

\section{Art. $4^{\underline{0}}$ São diretrizes da PNPDEC:}

I - atuação articulada entre a União, os Estados, o Distrito Federal e os Municípios para redução de desastres e apoio às comunidades atingidas;

II - abordagem sistêmica das ações de prevenção, mitigação, preparação, resposta e recuperação;

III - a prioridade às ações preventivas relacionadas à minimização de desastres;

IV - adoção da bacia hidrográfica como unidade de análise das ações de prevenção de desastres relacionados a corpos d'água;

$\mathrm{V}$ - planejamento com base em pesquisas e estudos sobre áreas de risco e incidência de desastres no território nacional;

VI - participação da sociedade civil.

Art. $5^{\circ}$ São objetivos da PNPDEC:

I - reduzir os riscos de desastres;

II - prestar socorro e assistência às populações atingidas por desastres;

III - recuperar as áreas afetadas por desastres;

IV - incorporar a redução do risco de desastre e as ações de proteção e defesa civil entre os elementos da gestão territorial e do planejamento das políticas setoriais;

V - promover a continuidade das ações de proteção e defesa civil;

VI - estimular o desenvolvimento de cidades resilientes e os processos sustentáveis de urbanização;

VII - promover a identificação e avaliação das ameaças, suscetibilidades e vulnerabilidades a desastres, de modo a evitar ou reduzir sua ocorrência; 
VIII - monitorar os eventos meteorológicos, hidrológicos, geológicos, biológicos, nucleares, químicos e outros potencialmente causadores de desastres; naturais;

IX - produzir alertas antecipados sobre a possibilidade de ocorrência de desastres

X - estimular o ordenamento da ocupação do solo urbano e rural, tendo em vista sua conservação e a proteção da vegetação nativa, dos recursos hídricos e da vida humana;

XI - combater a ocupação de áreas ambientalmente vulneráveis e de risco e promover a realocação da população residente nessas áreas;

XII - estimular iniciativas que resultem na destinação de moradia em local seguro;

XIII - desenvolver consciência nacional acerca dos riscos de desastre;

XIV - orientar as comunidades a adotar comportamentos adequados de prevenção e de resposta em situação de desastre e promover a autoproteção; e

XV - integrar informações em sistema capaz de subsidiar os órgãos do SINPDEC na previsão e no controle dos efeitos negativos de eventos adversos sobre a população, os bens e serviços e o meio ambiente.

\section{Seção II}

Das Competências dos Entes Federados

Art. $6^{\circ}$ Compete à União:

I - expedir normas para implementação e execução da PNPDEC; Municípios;

II - coordenar o SINPDEC, em articulação com os Estados, o Distrito Federal e os

III - promover estudos referentes às causas e possibilidades de ocorrência de desastres de qualquer origem, sua incidência, extensão e consequência;

IV - apoiar os Estados, o Distrito Federal e os Municípios no mapeamento das áreas de risco, nos estudos de identificação de ameaças, suscetibilidades, vulnerabilidades e risco de desastre e nas demais ações de prevenção, mitigação, preparação, resposta e recuperação;

V - instituir e manter sistema de informações e monitoramento de desastres;

VI - instituir e manter cadastro nacional de municípios com áreas suscetíveis à ocorrência de deslizamentos de grande impacto, inundações bruscas ou processos geológicos ou hidrológicos correlatos;

VII - instituir e manter sistema para declaração e reconhecimento de situação de emergência ou de estado de calamidade pública;

VIII - instituir o Plano Nacional de Proteção e Defesa Civil;

IX - realizar o monitoramento meteorológico, hidrológico e geológico das áreas de risco, bem como dos riscos biológicos, nucleares e químicos, e produzir alertas sobre a possibilidade de ocorrência de desastres, em articulação com os Estados, o Distrito Federal e os Municípios; 
$X$ - estabelecer critérios e condições para a declaração e o reconhecimento de situações de emergência e estado de calamidade pública;

$\mathrm{XI}$ - incentivar a instalação de centros universitários de ensino e pesquisa sobre desastres e de núcleos multidisciplinares de ensino permanente e a distância, destinados à pesquisa, extensão e capacitação de recursos humanos, com vistas no gerenciamento e na execução de atividades de proteção e defesa civil;

XII - fomentar a pesquisa sobre os eventos deflagradores de desastres; e

XIII - apoiar a comunidade docente no desenvolvimento de material didático-pedagógico relacionado ao desenvolvimento da cultura de prevenção de desastres.

$\S 1^{\circ}$ O Plano Nacional de Proteção e Defesa Civil conterá, no mínimo:

I - a identificação dos riscos de desastres nas regiões geográficas e grandes bacias hidrográficas do País; e

II - as diretrizes de ação governamental de proteção e defesa civil no âmbito nacional e regional, em especial quanto à rede de monitoramento meteorológico, hidrológico e geológico e dos riscos biológicos, nucleares e químicos e à produção de alertas antecipados das regiões com risco de desastres.

$\S 2^{\circ}$ Os prazos para elaboração e revisão do Plano Nacional de Proteção e Defesa Civil serão definidos em regulamento.

Art. $7^{\circ}$ Compete aos Estados:

I - executar a PNPDEC em seu âmbito territorial;

II - coordenar as ações do SINPDEC em articulação com a União e os Municípios;

III - instituir o Plano Estadual de Proteção e Defesa Civil;

IV - identificar e mapear as áreas de risco e realizar estudos de identificação de ameaças, suscetibilidades e vulnerabilidades, em articulação com a União e os Municípios;

V - realizar o monitoramento meteorológico, hidrológico e geológico das áreas de risco, em articulação com a União e os Municípios;

VI - apoiar a União, quando solicitado, no reconhecimento de situação de emergência e estado de calamidade pública;

VII - declarar, quando for o caso, estado de calamidade pública ou situação de emergência; e

VIII - apoiar, sempre que necessário, os Municípios no levantamento das áreas de risco, na elaboração dos Planos de Contingência de Proteção e Defesa Civil e na divulgação de protocolos de prevenção e alerta e de ações emergenciais.

Parágrafo único. O Plano Estadual de Proteção e Defesa Civil conterá, no mínimo:

I - a identificação das bacias hidrográficas com risco de ocorrência de desastres; e 
II - as diretrizes de ação governamental de proteção e defesa civil no âmbito estadual, em especial no que se refere à implantação da rede de monitoramento meteorológico, hidrológico e geológico das bacias com risco de desastre.

Art. $8^{\circ}$ Compete aos Municípios:

I - executar a PNPDEC em âmbito local; Estados;

II - coordenar as ações do SINPDEC no âmbito local, em articulação com a União e os

III - incorporar as ações de proteção e defesa civil no planejamento municipal;

IV - identificar e mapear as áreas de risco de desastres;

V - promover a fiscalização das áreas de risco de desastre e vedar novas ocupações nessas áreas;

VI - declarar situação de emergência e estado de calamidade pública;

VII - vistoriar edificações e áreas de risco e promover, quando for o caso, a intervenção preventiva e a evacuação da população das áreas de alto risco ou das edificações vulneráveis;

VIII - organizar e administrar abrigos provisórios para assistência à população em situação de desastre, em condições adequadas de higiene e segurança;

IX - manter a população informada sobre áreas de risco e ocorrência de eventos extremos, bem como sobre protocolos de prevenção e alerta e sobre as ações emergenciais em circunstâncias de desastres;

X - mobilizar e capacitar os radioamadores para atuação na ocorrência de desastre;

$\mathrm{XI}$ - realizar regularmente exercícios simulados, conforme Plano de Contingência de Proteção e Defesa Civil; desastre;

XII - promover a coleta, a distribuição e o controle de suprimentos em situações de

XIII - proceder à avaliação de danos e prejuízos das áreas atingidas por desastres;

XIV - manter a União e o Estado informados sobre a ocorrência de desastres e as atividades de proteção civil no Município;

$\mathrm{XV}$ - estimular a participação de entidades privadas, associações de voluntários, clubes de serviços, organizações não governamentais e associações de classe e comunitárias nas ações do SINPDEC e promover o treinamento de associações de voluntários para atuação conjunta com as comunidades apoiadas; e

XVI - prover solução de moradia temporária às famílias atingidas por desastres.

Art. 9ํㅡㄹ Compete à União, aos Estados e aos Municípios:

I - desenvolver cultura nacional de prevenção de desastres, destinada ao desenvolvimento da consciência nacional acerca dos riscos de desastre no País; 
II - estimular comportamentos de prevenção capazes de evitar ou minimizar a ocorrência de desastres;

III - estimular a reorganização do setor produtivo e a reestruturação econômica das áreas atingidas por desastres;

IV - estabelecer medidas preventivas de segurança contra desastres em escolas e hospitais situados em áreas de risco;

e

V - oferecer capacitação de recursos humanos para as ações de proteção e defesa civil;

VI - fornecer dados e informações para o sistema nacional de informações e monitoramento de desastres.

\section{CAPÍTULO III}

\section{DO SISTEMA NACIONAL DE PROTEÇÃO E DEFESA CIVIL - SINPDEC}

\section{Seção I}

\section{Disposições Gerais}

Art. 10. O SINPDEC é constituído pelos órgãos e entidades da administração pública federal, dos Estados, do Distrito Federal e dos Municípios e pelas entidades públicas e privadas de atuação significativa na área de proteção e defesa civil.

Parágrafo único. O SINPDEC tem por finalidade contribuir no processo de planejamento, articulação, coordenação e execução dos programas, projetos e ações de proteção e defesa civil.

Art. 11. O SINPDEC será gerido pelos seguintes órgãos:

I - órgão consultivo: CONPDEC;

II - órgão central, definido em ato do Poder Executivo federal, com a finalidade de coordenar o sistema;

III - os órgãos regionais estaduais e municipais de proteção e defesa civil; e

IV - órgãos setoriais dos 3 (três) âmbitos de governo.

Parágrafo único. Poderão participar do SINPDEC as organizações comunitárias de caráter voluntário ou outras entidades com atuação significativa nas ações locais de proteção e defesa civil.

\section{Seção II}

Do Conselho Nacional de Proteção e Defesa Civil - CONPDEC

Art. 12. O CONPDEC, órgão colegiado integrante do Ministério da Integração Nacional, terá por finalidades: 
I - auxiliar na formulação, implementação e execução do Plano Nacional de Proteção e Defesa Civil;

II - propor normas para implementação e execução da PNPDEC;

III - expedir procedimentos para implementação, execução e monitoramento da PNPDEC, observado o disposto nesta Lei e em seu regulamento;

IV - propor procedimentos para atendimento a crianças, adolescentes, gestantes, idosos e pessoas com deficiência em situação de desastre, observada a legislação aplicável; e defesa civil.

V - acompanhar o cumprimento das disposições legais e regulamentares de proteção e

§ $1^{\circ}$ A organização, a composição e o funcionamento do CONPDEC serão estabelecidos em ato do Poder Executivo federal.

$\S 2^{\circ}$ O CONPDEC contará com representantes da União, dos Estados, do Distrito Federal, dos Municípios e da sociedade civil organizada, incluindo-se representantes das comunidades atingidas por desastre, e por especialistas de notório saber.

\section{CAPÍTULO IV}

\section{DISPOSIÇÕES FINAIS}

Art. 13. Fica autorizada a criação de sistema de informações de monitoramento de desastres, em ambiente informatizado, que atuará por meio de base de dados compartilhada entre os integrantes do SINPDEC visando ao oferecimento de informações atualizadas para prevenção, mitigação, alerta, resposta e recuperação em situações de desastre em todo o território nacional.

Art. 14. Os programas habitacionais da União, dos Estados, do Distrito Federal e dos Municípios devem priorizar a relocação de comunidades atingidas e de moradores de áreas de risco.

Art. 15. A União poderá manter linha de crédito específica, por intermédio de suas agências financeiras oficiais de fomento, destinada ao capital de giro e ao investimento de sociedades empresariais, empresários individuais e pessoas físicas ou jurídicas em Municípios atingidos por desastre que tiverem a situação de emergência ou o estado de calamidade pública reconhecido pelo Poder Executivo federal.

Art. 16. Fica a União autorizada a conceder incentivo ao Município que adotar medidas voltadas ao aumento da oferta de terra urbanizada para utilização em habitação de interesse social, por meio dos institutos previstos na Lei $n^{\circ} 10.257$, de 10 de julho de 2001, na forma do regulamento.

Parágrafo único. O incentivo de que trata o caput compreenderá a transferência de recursos para a aquisição de terrenos destinados a programas de habitação de interesse social.

Art. 17. Em situações de iminência ou ocorrência de desastre, ficam os órgãos competentes autorizados a transferir bens apreendidos em operações de combate e repressão a crimes para os órgãos de proteção e defesa civil. civil:

Art. 18. Para fins do disposto nesta Lei, consideram-se agentes de proteção e defesa 
I - os agentes políticos da União, dos Estados, do Distrito Federal e dos Municípios responsáveis pela direção superior dos órgãos do SINPDEC;

II - os agentes públicos responsáveis pela coordenação e direção de órgãos ou entidades públicas prestadores dos serviços de proteção e defesa civil;

III - os agentes públicos detentores de cargo, emprego ou função pública, civis ou militares, com atribuições relativas à prestação ou execução dos serviços de proteção e defesa civil; e

IV - os agentes voluntários, vinculados a entidades privadas ou prestadores de serviços voluntários que exercem, em caráter suplementar, serviços relacionados à proteção e defesa civil.

Parágrafo único. Os órgãos do SINPDEC adotarão, no âmbito de suas competências, as medidas pertinentes para assegurar a profissionalização e a qualificação, em caráter permanente, dos agentes públicos referidos no inciso III.

Art. 19. Aplicam-se ao Distrito Federal as competências atribuídas nesta Lei aos Estados e aos Municípios.

Art. 20. A ementa da Lei $\mathrm{n}^{\circ} 12.340$, de $1^{\circ}$ de dezembro de 2010 , passa a vigorar com a seguinte redação:

"Dispõe sobre as transferências de recursos da União aos órgãos e entidades dos Estados, Distrito Federal e Municípios para a execução de ações de resposta e recuperação nas áreas atingidas por desastre, e sobre o Fundo Especial para Calamidades Públicas; e dá outras providências."

Art. 21. Os arts. $4^{\circ}$ e $5^{\circ}$ da Lei $n^{\circ} 12.340$, de 10 de dezembro de 2010 , passam a vigorar com a seguinte redação:

"Art. $4^{\circ}$ São obrigatórias as transferências da União aos órgãos e entidades dos Estados, do Distrito Federal e dos Municípios para a execução de ações de resposta e recuperação, observados os requisitos e procedimentos previstos nesta Lei.

$\S 1^{\circ}$ As ações de que trata o caput serão definidas em regulamento, e o órgão central do SINPDEC definirá o montante de recursos a ser transferido, mediante depósito em conta específica mantida pelo ente beneficiário em instituição financeira oficial federal, de acordo com sua disponibilidade orçamentária e financeira e com base nas informações obtidas perante o ente federativo.

$\S 2^{\circ}$ No caso de execução de ações de recuperação, o ente beneficiário deverá apresentar plano de trabalho ao órgão central do SINPDEC no prazo máximo de 90 (noventa) dias da ocorrência do desastre." (NR)

"Art. $5^{\circ} \mathrm{O}$ órgão central do SINPDEC acompanhará e fiscalizará a aplicação dos recursos transferidos na forma do art. $4^{\circ}$.

$\S 2^{\circ}$ Os entes beneficiários das transferências de que trata o caput deverão apresentar ao órgão central do SINPDEC a prestação de contas do total dos recursos recebidos, na forma do regulamento. 
$\S 3^{\circ}$ Os entes beneficiários manterão, pelo prazo de 5 (cinco) anos, contados da data de aprovação da prestação de contas de que trata o $\S 2^{\circ}$, os documentos a ela referentes, inclusive os comprovantes de pagamentos efetuados com os recursos financeiros transferidos na forma desta Lei, ficando obrigados a disponibilizá-los, sempre que solicitado, ao órgão central do SINPDEC, ao Tribunal de Contas da União e ao Sistema de Controle Interno do Poder Executivo federal." (NR)

Art. 22. A Lei $n^{\circ} 12.340$, de 10 de dezembro de 2010 , passa a vigorar acrescida dos seguintes arts. $3^{\circ}-\mathrm{A}, 3^{\circ}-\mathrm{B}$ e $5^{\circ}-\mathrm{A}^{\mathrm{A}}$

"Art. $3^{\circ}$-A. O Governo Federal instituirá cadastro nacional de municípios com áreas suscetíveis à ocorrência de deslizamentos de grande impacto, inundações bruscas ou processos geológicos ou hidrológicos correlatos, conforme regulamento.

$\S 1^{\circ} \mathrm{A}$ inscrição no cadastro previsto no caput dar-se-á por iniciativa do Município ou mediante indicação dos demais entes federados, observados os critérios e procedimentos previstos em regulamento.

$\S 2^{\circ}$ Os Municípios incluídos no cadastro deverão:

I - elaborar mapeamento contendo as áreas suscetíveis à ocorrência de deslizamentos de grande impacto, inundações bruscas ou processos geológicos ou hidrológicos correlatos;

II - elaborar Plano de Contingência de Proteção e Defesa Civil e instituir órgãos municipais de defesa civil, de acordo com os procedimentos estabelecidos pelo órgão central do Sistema Nacional de Proteção e Defesa Civil - SINPDEC; desastre;

III - elaborar plano de implantação de obras e serviços para a redução de riscos de

IV - criar mecanismos de controle e fiscalização para evitar a edificação em áreas suscetíveis à ocorrência de deslizamentos de grande impacto, inundações bruscas ou processos geológicos ou hidrológicos correlatos; e

V - elaborar carta geotécnica de aptidão à urbanização, estabelecendo diretrizes urbanísticas voltadas para a segurança dos novos parcelamentos do solo e para o aproveitamento de agregados para a construção civil.

$\S 3^{\circ}$ A União e os Estados, no âmbito de suas competências, apoiarão os Municípios na efetivação das medidas previstas no $\S 2^{\circ}$.

$\S 4^{\circ}$ Sem prejuízo das ações de monitoramento desenvolvidas pelos Estados e Municípios, o Governo Federal publicará, periodicamente, informações sobre a evolução das ocupações em áreas suscetíveis à ocorrência de deslizamentos de grande impacto, inundações bruscas ou processos geológicos ou hidrológicos correlatos nos Municípios constantes do cadastro.

$\S 5^{\circ}$ As informações de que trata o $\S 4^{\circ}$ serão encaminhadas, para conhecimento e providências, aos Poderes Executivo e Legislativo dos respectivos Estados e Municípios e ao Ministério Público.

$\S 6^{\circ}$ O Plano de Contingência de Proteção e Defesa Civil será elaborado no prazo de 1 (um) ano, sendo submetido a avaliação e prestação de contas anual, por meio de audiência pública, com ampla divulgação." 
"Art. $3^{\circ}$-B. Verificada a existência de ocupações em áreas suscetíveis à ocorrência de deslizamentos de grande impacto, inundações bruscas ou processos geológicos ou hidrológicos correlatos, o município adotará as providências para redução do risco, dentre as quais, a execução de plano de contingência e de obras de segurança e, quando necessário, a remoção de edificações e o reassentamento dos ocupantes em local seguro.

$\S 1^{0}$ A efetivação da remoção somente se dará mediante a prévia observância dos seguintes procedimentos:

I - realização de vistoria no local e elaboração de laudo técnico que demonstre os riscos da ocupação para a integridade física dos ocupantes ou de terceiros; e

II - notificação da remoção aos ocupantes acompanhada de cópia do laudo técnico e, quando for o caso, de informações sobre as alternativas oferecidas pelo poder público para assegurar seu direito à moradia.

$\S 2^{\circ}$ Na hipótese de remoção de edificações, deverão ser adotadas medidas que impeçam a reocupação da área.

$\S 3^{\circ}$ Aqueles que tiverem suas moradias removidas deverão ser abrigados, quando necessário, e cadastrados pelo Município para garantia de atendimento habitacional em caráter definitivo, de acordo com os critérios dos programas públicos de habitação de interesse social."

"Art. 5-A. Constatada, a qualquer tempo, a presença de vícios nos documentos apresentados, ou a inexistência do estado de calamidade pública ou da situação de emergência declarados, o ato administrativo que tenha autorizado a realização da transferência obrigatória perderá seus efeitos, ficando o ente beneficiário obrigado a devolver os valores repassados, devidamente atualizados.

Parágrafo único. Sem prejuízo do disposto no caput, ocorrendo indícios de falsificação de documentos pelo ente federado, deverão ser notificados o Ministério Público Federal e o Ministério Público Estadual respectivo, para adoção das providências cabíveis."

Art. 23. É vedada a concessão de licença ou alvará de construção em áreas de risco indicadas como não edificáveis no plano diretor ou legislação dele derivada.

Art. 24. O inciso VI do art. $2^{\circ}$ da Lei $n^{\circ} 10.257$, de 10 de julho de 2001, passa a vigorar acrescido da seguinte alínea $h$ :

"Art. $2^{\circ}$

$\mathrm{VI}-$

h) a exposição da população a riscos de desastres.

(NR). 
Art. 25. O art. 41 da Lei $n^{\circ} 10.257$, de 10 de julho de 2001, passa a vigorar acrescido do seguinte inciso $\mathrm{Vl}$ :

"Art. 41.

VI - incluídas no cadastro nacional de Municípios com áreas suscetíveis à ocorrência de deslizamentos de grande impacto, inundações bruscas ou processos geológicos ou hidrológicos correlatos.

\section{.$"(N R)$}

Art. 26. A Lei $\mathrm{n}^{\circ} 10.257$, de 10 de julho de 2001 , passa a vigorar acrescida dos seguintes arts. 42-A e 42-B:

"Art. 42-A. Além do conteúdo previsto no art. 42, o plano diretor dos Municípios incluídos no cadastro nacional de municípios com áreas suscetíveis à ocorrência de deslizamentos de grande impacto, inundações bruscas ou processos geológicos ou hidrológicos correlatos deverá conter:

I - parâmetros de parcelamento, uso e ocupação do solo, de modo a promover a diversidade de usos e a contribuir para a geração de emprego e renda;

II - mapeamento contendo as áreas suscetíveis à ocorrência de deslizamentos de grande impacto, inundações bruscas ou processos geológicos ou hidrológicos correlatos;

III - planejamento de ações de intervenção preventiva e realocação de população de áreas de risco de desastre;

IV - medidas de drenagem urbana necessárias à prevenção e à mitigação de impactos de desastres; e

V - diretrizes para a regularização fundiária de assentamentos urbanos irregulares, se houver, observadas a Lei $n^{\circ}$ 11.977, de 7 de julho de 2009, e demais normas federais e estaduais pertinentes, e previsão de áreas para habitação de interesse social por meio da demarcação de zonas especiais de interesse social e de outros instrumentos de política urbana, onde o uso habitacional for permitido.

$\S 1^{0} \mathrm{~A}$ identificação e o mapeamento de áreas de risco levarão em conta as cartas geotécnicas.

$\S 2^{\circ}$ O conteúdo do plano diretor deverá ser compatível com as disposições insertas nos planos de recursos hídricos, formulados consoante a Lei n⿳⺈ 9.433, de 8 de janeiro de 1997.

$\S 3^{\circ}$ Os Municípios adequarão o plano diretor às disposições deste artigo, por ocasião de sua revisão, observados os prazos legais.

$\S 4^{\circ}$ Os Municípios enquadrados no inciso VI do art. 41 desta Lei e que não tenham plano diretor aprovado terão o prazo de 5 (cinco) anos para o seu encaminhamento para aprovação pela Câmara Municipal." 
"Art. 42-B. Os Municípios que pretendam ampliar o seu perímetro urbano após a data de publicação desta Lei deverão elaborar projeto específico que contenha, no mínimo:

I - demarcação do novo perímetro urbano;

II - delimitação dos trechos com restrições à urbanização e dos trechos sujeitos a controle especial em função de ameaça de desastres naturais;

III - definição de diretrizes específicas e de áreas que serão utilizadas para infraestrutura, sistema viário, equipamentos e instalações públicas, urbanas e sociais;

IV - definição de parâmetros de parcelamento, uso e ocupação do solo, de modo a promover a diversidade de usos e contribuir para a geração de emprego e renda;

V - a previsão de áreas para habitação de interesse social por meio da demarcação de zonas especiais de interesse social e de outros instrumentos de política urbana, quando o uso habitacional for permitido;

VI - definição de diretrizes e instrumentos específicos para proteção ambiental e do patrimônio histórico e cultural; e

VII - definição de mecanismos para garantir a justa distribuição dos ônus e benefícios decorrentes do processo de urbanização do território de expansão urbana e a recuperação para a coletividade da valorização imobiliária resultante da ação do poder público.

$\S 1^{\circ} \mathrm{O}$ projeto específico de que trata o caput deste artigo deverá ser instituído por lei municipal e atender às diretrizes do plano diretor, quando houver.

$\S 2^{\circ}$ Quando o plano diretor contemplar as exigências estabelecidas no caput, o Município ficará dispensado da elaboração do projeto específico de que trata o caput deste artigo.

$\S 3^{\circ}$ A aprovação de projetos de parcelamento do solo no novo perímetro urbano ficará condicionada à existência do projeto específico e deverá obedecer às suas disposições."

Art. 27. O art. 12 da Lei $\mathrm{n}^{\circ} 6.766$, de 19 de dezembro de 1979 , passa a vigorar com a seguinte redação, renumerando-se 0 atual parágrafo único para $\S 1^{\circ}$ :

"Art. 12.

$\S 1^{\circ} \mathrm{O}$ projeto aprovado deverá ser executado no prazo constante do cronograma de execução, sob pena de caducidade da aprovação.

$\S 2^{0}$ Nos Municípios inseridos no cadastro nacional de municípios com áreas suscetíveis à ocorrência de deslizamentos de grande impacto, inundações bruscas ou processos geológicos ou hidrológicos correlatos, a aprovação do projeto de que trata o caput ficará vinculada ao atendimento dos requisitos constantes da carta geotécnica de aptidão à urbanização. Vigência

$\S 3^{0}$ É vedada a aprovação de projeto de loteamento e desmembramento em áreas de risco definidas como não edificáveis, no plano diretor ou em legislação dele derivada." (NR)

Art. 28. O art. $3^{\circ}$ da Lei $n^{\circ} 8.239$, de 4 de outubro de 1991 , que regulamenta os $\S \S 1^{\circ} \mathrm{e}$ $2^{\circ}$ do art. 143 da Constituição Federal, que dispõem sobre a prestação de Serviço Alternativo ao Serviço Militar Obrigatório, passa a vigorar acrescido dos seguintes $\S \S 4^{\circ}$ e $5^{\circ}$. 
“Art. 3

$\S 4^{\circ}$ O Serviço Alternativo incluirá o treinamento para atuação em áreas atingidas por desastre, em situação de emergência e estado de calamidade, executado de forma integrada com o órgão federal responsável pela implantação das ações de proteção e defesa civil.

$\S 5^{\circ}$ A União articular-se-á com os Estados e o Distrito Federal para a execução do treinamento a que se refere o $\S 4^{\circ}$ deste artigo." (NR)

Art. 29. O art. 26 da Lei $n^{\circ} 9.394$, de 20 de dezembro de 1996, que estabelece as diretrizes e bases da educação nacional, passa a vigorar acrescido do seguinte $\S 7^{\circ}$ :

"Art. 26.

$\S 7^{\circ}$ Os currículos do ensino fundamental e médio devem incluir os princípios da proteção e defesa civil e a educação ambiental de forma integrada aos conteúdos obrigatórios." (NR) $\underline{2010}$.

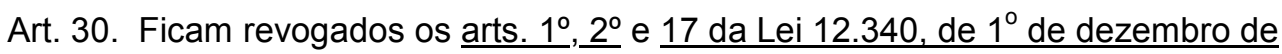

Art. 31. Esta Lei entra em vigor na data de sua publicação, com exceção do disposto no $\S 2^{\circ}$ do art. 12 da Lei $n^{\circ} 6.766$, de 19 de dezembro de 1979 , que entrará em vigor após decorridos 2 (dois) anos da data de sua publicação oficial.

Brasília, 10 de abril de 2012; $191^{\circ}$ da Independência e 124ํํำ da República.

MICHEL TEMER

José Eduardo Cardozo

Luiz Antonio Rodríguez Elias

Izabella Mónica Vieira Teixeira

Alexandre Navarro Garcia

Alexandre Cordeiro Macedo

Este texto não substitui o publicado no DOU de 11.4.2012 